Ship Effects Before and After Deepening of Sabine-Neches Waterway, Port Arthur, Texas

US Army Corps of Engineers ${ }_{\circledast}$

Engineer Research and Development Center

Stephen T. Maynord

September 2003 


\section{Ship Effects Before and After Deepening of Sabine-Neches Waterway, Port Arthur, Texas}

Stephen T. Maynord

Coastal and Hydraulics Laboratory

U.S. Army Engineer Research and Development Center

3909 Halls Ferry Road

Vicksburg, MS 39180-6199

Final report

Approved for public release; distribution is unlimited

Prepared for U.S. Army Engineer District, Galveston

Galveston, TX 77553-1229

and U.S. Army Corps of Engineers

Washington, DC 20314-1000 


\begin{abstract}
The Sabine Neches Waterway is a confined navigation channel with a shallow berm adjacent to the navigation channel whose berm width varies from near zero to more than $800 \mathrm{ft}$ in the Sabine-Neches Canal. Ship effects that attack the bank and possibly lead to bank erosion were compared in the before and after enlargement of the channel. Ship speed is the most critical and most difficult parameter to define in such a comparison. At ship speeds typically found in the SNWW, the shallow berm results in a large breaking wave forming adjacent to the shoreline. This wave, referred to herein as the transverse stern wave (TSW), moves at the ship speed and has a magnitude of up to $5.5 \mathrm{ft}$ based on measurements reported herein and is calculated to be up to $8.4 \mathrm{ft}$ for extremely fast ships in the proposed channel. The TSW is used herein to quantify and compare ship effects on the shoreline.

HIVEL2D is a two-dimensional numerical model that was used herein to compare ship effects at SNWW. The model was validated using data from one of the ships measured during the field data collection portion of this study.

Two scenarios were evaluated that have the potential for increased bank attack in the proposed channel. The first scenario is that ships currently using the SNWW will be able to travel faster in the larger proposed channel resulting in an increase in bank attack. The second scenario is that future ships will be larger than those using the existing SNWW and will cause larger bank attack. The two bank attack scenarios were evaluated using a range of speeds for ships in the existing and proposed channels.

Results show that at the lower end of the range of speeds evaluated in the proposed channels, the TSW will increase in height less than 10 percent for both bank attack scenarios in both the Port Arthur and Sabine-Neches Canals. At the upper end of the range of speeds evaluated in the proposed channels, the TSW will increase an average of 35 percent in the Port Arthur Canal and an average of 17 percent in the Sabine-Neches Canal for both bank attack scenarios. The lesser change in the Sabine-Neches Canal is due to the smaller increase in cross section and the wider berm.

Speed restriction tests were conducted with the proposed channel to determine speeds that will (a) result in equal TSW in the existing and proposed channels and (b) lessen TSW in the proposed channel compared to the existing channel.
\end{abstract}

DISCLAIMER: The contents of this report are not to be used for advertising, publication, or promotional purposes. Citation of trade names does not constitute an official endorsement or approval of the use of such commercial products. All product names and trademarks cited are the property of their respective owners. The findings of this report are not to be construed as an official Department of the Army position unless so designated by other authorized documents. 


\section{Contents}

Conversion Factors, Non-SI to SI Units of Measurement ..................................

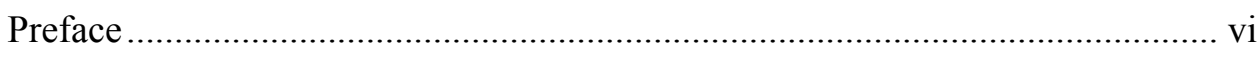

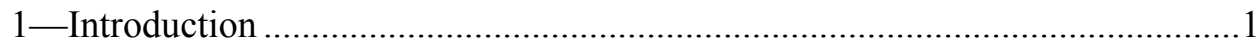

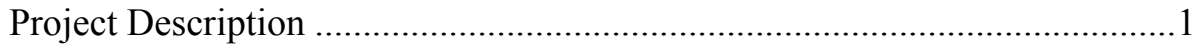

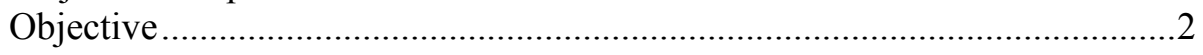

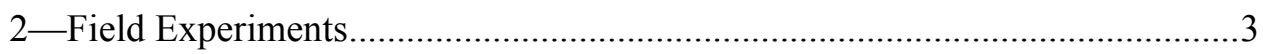

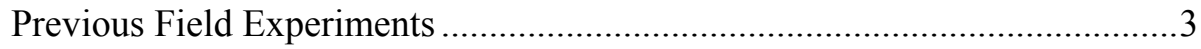

General Description of Present Field Studies .............................................. 3

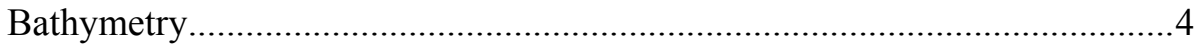

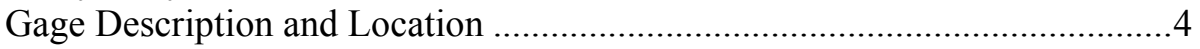

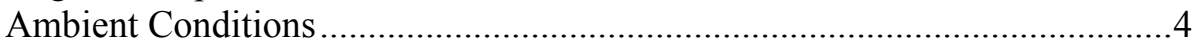

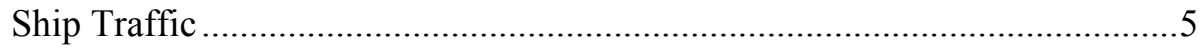

Time-Histories of Water Level and Drawdown and Surge Data ......................5

Validation Ship for Existing Channel ...........................................................5

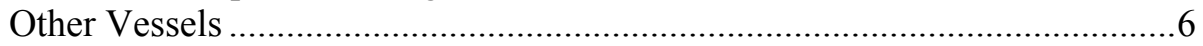

3-Ship Speeds and Ship Sizes Used in Comparison ........................................ 7

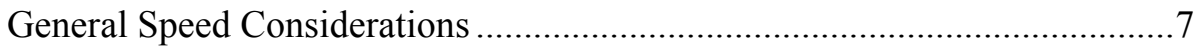

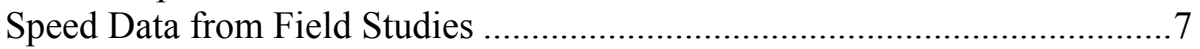

Design Ship in Existing and Proposed Waterway ........................................8

Larger Ship in Proposed Channel .................................................................8

Observed Ship Speed in Existing Channel .................................................. 9

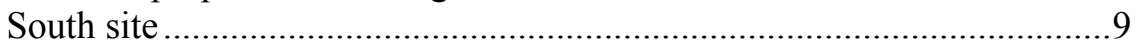

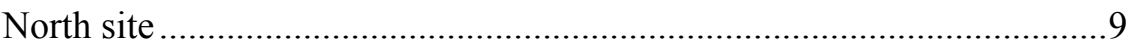

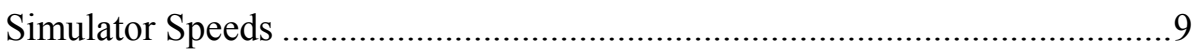

Proposed Channel Cross-Section Characteristics ......................................... 9

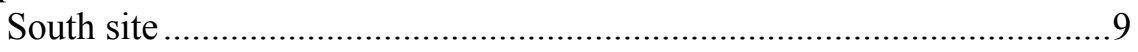

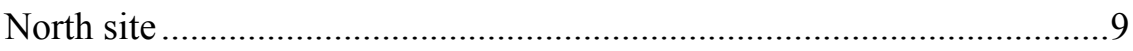

Rules Used in Ship Speed Selection .................................................... 10

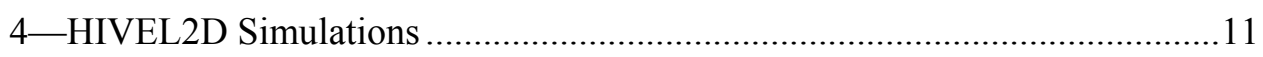

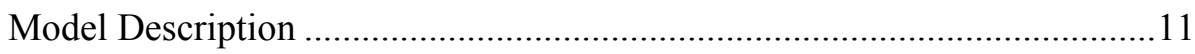

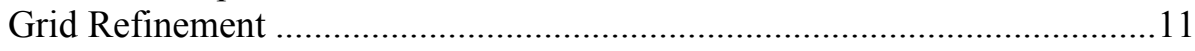

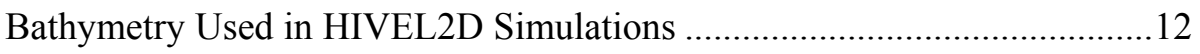

Pressure Field Representing Ship ...........................................................12

Adjustment of Ship Speed to Account for Tidal Currents .............................13 
Validation of HIVEL2D Using Existing Channel Data................................13

HIVEL2D Simulations at South Site .......................................................13

HIVEL2D Simulations at North Site .....................................................14

5-Surge and Transverse Stern Wave in Existing and Proposed Canals ..............15

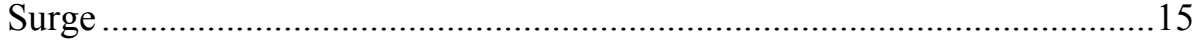

Transverse Stern Wave Comparison.......................................................16

6-Speed Restrictions in Proposed Channel ......................................................18

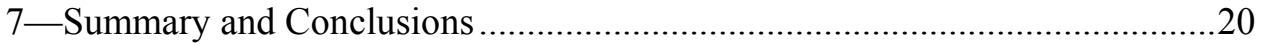

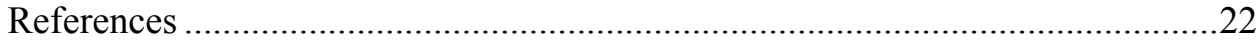

Figures 1-48

Tables 1-16

Appendix A: Time-Histories of Water Level, Existing Channel .......................A1 SF 298 


\section{Conversion Factors, Non-SI to SI Units of Measurement}

Non-SI units of measurement used in this report can be converted to SI units as follows:

\begin{tabular}{||l|l|l||}
\hline Multiply & By & To Obtain \\
\hline \hline cubic feet & 0.02831685 & cubic meters \\
\hline degrees (angle) & 0.01745329 & radians \\
\hline feet & 0.3048 & meters \\
\hline knots (international) & 0.5144444 & meters per second \\
\hline miles (U.S. statute) & 1.609347 & kilometers \\
\hline square feet & 0.09290304 & square meters \\
\hline \hline
\end{tabular}




\section{Preface}

The work reported herein was conducted for the U.S. Army Engineer District, Galveston. The field work was performed during April-May 2002 by personnel of U.S. Army Engineer Research and Development Center (ERDC). Messrs. Terry Waller, Sam Varnell, Mile Kirkland, Chris Callegan, and Dr. Stephen Maynord participated in the field studies. The numerical modeling of ship effects was conducted by Dr. Maynord, who also wrote the report.

The study was under the direction of Mr. Thomas W. Richardson, Director, Coastal and Hydraulics Laboratory (CHL); Dr. William D. Martin, Deputy Director/Chief of Staff, CHL; Mr. Tom Pokrefke, Deputy Chief of Staff; and Mr. Donald Wilson, Chief of the Navigation Branch, CHL.

COL James R. Rowan, EN, was Commander and Executive Director of ERDC. Dr. James R. Houston was Director. 


\section{Introduction}

\section{Project Description}

The Sabine-Neches Waterway (SNWW) is located in southeast Texas and provides access to the Gulf of Mexico for the harbor facilities of Sabine Pass, Port Arthur, Beaumont, and Orange, TX (Figure 1). The existing project has an authorized depth of $40 \mathrm{ft}^{1}$ and includes approximately 65 miles of deep-draft navigation channels. The waterway consists of the Sabine Bank and Sabine Pass outer bar channels ( $42 \mathrm{ft}$ by $800 \mathrm{ft}$ ), Sabine Pass jetty channel (42 ft by $800 \mathrm{ft}$ narrowing to $500 \mathrm{ft}$ ), Sabine Pass Channel and Port Arthur Canal (40 ft by $500 \mathrm{ft}$ ), Sabine-Neches Canal and Neches River Channel (40 ft by $400 \mathrm{ft}$ ), and the Sabine-Neches Canal to Sabine River (30 ft by $200 \mathrm{ft}$ ). This study focuses on the Port Arthur and Sabine-Neches Canals in the reach adjacent to Pleasure Island.

Vessels using the SNWW include ships, barges, service boats, and recreational boats. Due to the large petrochemical industry in the area, most ships using the waterway are tankers. Since the deepening was done to address ship traffic, this report focuses on the changes in ship effects in the existing and deepened channels.

Ship effects in navigation channels can be broadly classified as short period and long period. Short period effects include waves formed at the bow and stern and, in some cases, short period waves that result from drawdown of the water level in shallow water for high-speed ships. Long period effects include drawdown of the water level, return velocity, and surge of the water level above the ambient level. Immediately following the drawdown, a transverse stern wave (TSW) can form, depending on ship speed, and is often the dominant loading on the bank (Figure 2). Long period effects of a ship increase with increasing speed and increasing blockage factor, the ratio of ship cross-sectional area to channel area. Navigation channels with blockage ratios exceeding 0.05 to 0.10 are classified as confined or restricted. The largest ships at SNWW along Pleasure Island have blockage ratios of about 0.2 . SNWW is typical of several deep-draft ship channels in that it has a shallow berm between the shoreline and the navigation channel.

1 A table of factors for converting non-SI units of measurement to SI units is presented on page v. 


\section{Objective}

The U.S. Army Engineer District, Galveston, is proposing to deepen and, in some reaches, widen the SNWW. The District contracted with the U.S. Army Engineer Research and Development Center (ERDC) to determine the ship wave conditions in the existing canal and after deepening of the canal. The focus of this study is the reach adjacent to Pleasure Island. In the south portion of the island adjacent to the Port Arthur Canal, the channel is proposed to be deepened to $-50 \mathrm{ft}$ mean low tide (mlt) and widened to a bottom width of $700 \mathrm{ft}$. In the north portion of the island adjacent to the Sabine Neches Canal, the channel will be deepened to $-50 \mathrm{ft}$ mlt while remaining at $400 \mathrm{ft}$ bottom width. The north portion also includes a barge lane on the east side of the ship canal.

ERDC used field measurements in the existing canal and numerical modeling of the existing and deepened channels. This report evaluates change in bank erosion by quantifying change in ship-induced bank line forces. Two scenarios can lead to changes in ship-induced bank forces in the proposed SNWW channel:

a. Scenario 1-Ships presently using the SNWW will be able to go faster in the larger channel leading to changes in bank forces. This scenario is investigated herein by selecting a design ship and comparing the design ship effects in existing and proposed channels.

b. Scenario 2- Larger ships will use the proposed channel and bank forces will differ from ships in the existing channel. This scenario is investigated herein by selecting a larger ship and comparing forces from the design ship in the existing channel to the larger ship in the proposed channel.

In addition to comparing ship wave forces in existing and proposed channels, this study evaluates speed restrictions to a) limit ship waves in the proposed channel to those in the existing channel and b) reduce ship waves in the proposed channel to less than those in the existing channel. 


\section{Field Experiments}

\section{Previous Field Experiments}

Herbich et al. (1979) conducted field measurement of ship effects in the SNWW in a study prepared for the State Department of Highways and Public Transportation, Beaumont District. A progress report for that study was found but there was no further information other than a conference paper by Herbich and Schiller (1984). Phone calls were made to the authors, Texas A\&M University, and Texas Department of Transportation (TDOT). The Beaumont District office of the TDOT was visited but no additional information was found. The progress report and the conference paper included similar information. The conference paper uses the term "surge" that is equal to the transverse stern wave (TSW) used herein. In this report "surge" is the rise of the water level above the still-water level and surge plus drawdown is equal to the TSW. Herbich and Schiller (1984) concluded that TSW from large ships is considerably larger than short period waves from large ships. They also found short period waves from small vessels are much larger than TSW from small vessels. Their measurements indicated that TSW from large ships was larger than short period waves from small vessels. TSW height in the progress report of Herbich et al. (1979) was up to $10 \mathrm{ft}$. TSW height from all measurements in Herbich and Schiller (1984) was up to $5.8 \mathrm{ft}$ at a location on the Port Arthur Canal. The lack of the $10-\mathrm{ft}$ measured TSW in the later report casts some doubt on its validity.

\section{General Description of Present Field Studies}

The field investigation of the existing channel at SNWW was conducted from 30 April to 4 May 2002. During the field investigation, pressure cells, a velocity meter, and capacitance gages were deployed at the north and south sites along Pleasure Island (Figure 3) to measure waves and drawdown from passing ships, barges, and recreational boats. The north site is in the Sabine-Neches Canal and the south site is in the Port Arthur Canal. All gages were located on the shallow berm on the east side of the navigation channel adjacent to Pleasure Island. All times used in this report are in Central Standard Time (CST). 


\section{Bathymetry}

The Galveston District provided detailed bathymetry of the navigation channel, but data was not available for the shallow berm adjacent to the channel. During the field experiments, bathymetry measurements were made of the berm from the shoreline to the navigation channel in the vicinity of the instruments. For this reason, the numerical modeling is strictly applicable to the sites near the instruments, but conclusions are considered applicable to the reach because the north and south sites are representative of their respective reaches.

\section{Gage Description and Location}

Figure 3 shows the Pleasure Island reach including the locations of the pressure cells, capacitance gages, and the velocity gage. Table 1 shows the State Plane coordinates (NAD83, Texas South Central - 4204, in feet) of the pressure cells and the depth at mean low tide at each cell. Conversion from mlt to NAVD88 is: $\mathrm{mlt}=\mathrm{NAVD}+0.8 \mathrm{ft}$. At the south site, both pressure cells were at the shoreline. At the north site, both pressure cells were located in similar depths and similar distances from the ship channel to facilitate ship speed measurement. The wide shallow section at the north site resulted in the pressure cells being far from the shoreline. The pressure cells were mounted on temporary piles driven into the bay or attached to existing piles. The sensor in the pressure cells was positioned about $1 \mathrm{ft}$ above the channel bottom. The pressure cells measured data at $4 \mathrm{~Hz}$ during the field study which is valid for capturing the long period vessel drawdown but is not a high enough frequency to capture the short period waves. The pressure cell data were recorded for $19 \mathrm{~min} 50 \mathrm{sec}$ and stored for $10 \mathrm{sec}$. During the $10 \mathrm{sec}$ of storage, data were not collected.

Table 2 shows the location of the capacitance gages and the depth at mlt. The capacitance gages were rod type commercial gages having a length of $3 \mathrm{~m}$ and diameter of $5 \mathrm{~mm}$. The gages were set to record data at $10 \mathrm{~Hz}$ which provided good description of the short period vessel and wind waves. The mount and gage are shown in Figure 4. Galvanized steel pipe was driven into the bottom of the bay to support the capacitance gages which were spaced at about $55 \mathrm{ft}$ in an array perpendicular to the bank. The gages recorded data on a data logger that was set to record for $14 \mathrm{~min}$ and write to the hard disk for $1 \mathrm{~min}$. Data could not be collected during the $1 \mathrm{~min}$ of write to the hard disk. Consequently, some of the data records have a 1-min gap in the capacitance data.

The velocity gage was a bottom mounted acoustic gage that sampled velocity at various distances above the bottom. The gage was located immediately beside the channel capacitance gage at the south site.

\section{Ambient Conditions}

The Conrad Bucher tide gage at Port Arthur was used to obtain the ambient water levels during the field study. The tide range is typically up to about $1.5 \mathrm{ft}$. Tidal currents at SNWW are not large based on the observed velocity data. 


\section{Ship Traffic}

All ships using the SNWW are entered in a log that was provided by the Sabine pilots. The log provides vessel name, date of passage, direction of travel, vessel beam, length, and draft, vessel type, and times at various points along the waterway. The ship characteristics, date/time of passage, and water level description are shown in Table 3 for ships that passed the site during the field data collection.

\section{Time-Histories of Water Level and Drawdown and Surge Data}

Selected time-histories of the measured data collected in the existing channel are shown in Appendix A in Figures A1 to A29. The plotted data have not been filtered or averaged. Several features of the time-histories are as follows:

a. The datum for the time-histories was the ambient water level except for some of the capacitance gage plots which were offset from the ambient level by 1,2 , or $4 \mathrm{ft}$ to facilitate plotting. Figure A3 is an example where the shoreline gage has been offset by $2 \mathrm{ft}$.

$b$. Some of the drawdown went below the gage that resulted in a flat indication of water level such as Figure A1 at $790 \mathrm{sec}$.

c. The 10 -sec loss of data from the pressure cell while writing the data to the disk can be seen in Figure A13 at 1,190 sec.

Drawdown is the drop to the minimum water level during the event. Surge is the rise to the maximum water level during the event. Both drawdown and surge are measured from the average ambient water level. For defining drawdown and surge from the ship, the minimum and maximum water levels exclude any short period waves from the ship or wind. Tables 4 and 5 summarize drawdown and surge for the ships observed during the field study at the north and south sites, respectively.

\section{Validation Ship for Existing Channel}

A validation ship was needed to show that the HIVEL2D model (discussed in Chapter 4) could be used to model the long period ship effects of drawdown at SNWW. This requires selection of a typical ship for which field data were collected. The ship characteristics in Table 3 were evaluated for typical beam, length, draft, and water level. The drawdown and surge data in these tables were examined for ships producing drawdown and surge values that would not be classified as outliers. The Pacific Sapphire, which was inbound on 1 May 2002, was selected as the validation ship for the existing channel. The Pacific Sapphire had the characteristics shown in Table 6 . 


\section{Other Vessels}

Barges passed through the SNWW during the field experiments. Due to their small cross-sectional area and their slow speed compared to ships, drawdown from barges could not be detected in the measured time-history of water level for many of the barges. In all cases of barge passage, the magnitude of the barge drawdown was small compared to the ships.

Service and recreational boats passed the field measurement site and often caused significant wave activity. Speed of service and recreational boats should not be affected by the deepening. Wave activity from service and recreational boats may be greater where channel widths are increased because boats can travel closer to the bank line. Even with this potential increase due to closer proximity to the bank, wave height from service and recreational boats is small compared to the TSW from the ships. 


\section{Ship Speeds and Ship Sizes Used in Comparison}

\section{General Speed Considerations}

The most critical and most difficult part of any ship effects study is selecting comparable speeds in existing and proposed channels which is further complicated when ship sizes are proposed to increase. The speed selection almost entirely dictates the outcome of any comparison of ship effects under existing and proposed conditions. Ship speed is strongly affected by ship and channel size. In confined channels like the SNWW, the channel size relative to the ship size places a physical limit on the speed of displacement ships. The limit speed depends on the waterway cross-section area and shape, the vessel underwater cross-section area and, to a much lesser extent, the shape and length of the ship. The limit speed procedure used herein is documented in Maynord (1996). Past experience suggests that ships rarely travel at more than 80-90 percent of the limiting speed because the power required becomes extremely large as the ship approaches the limit speed. This report places great emphasis on relating ship speed to a percentage of limit speed because it provides a means of relating SNWW speed to speeds in other channels and provides a physical basis for speed projections. Channel alignment and the presence of mooring areas are other factors that can limit and further complicate selection of ship speed, particularly in proposed channels with proposed ships. All of these factors were considered in the speed recommendations.

\section{Speed Data from Field Studies}

Ship speed at SNWW was determined using two techniques as follows:

a. Bow to stern passage time was measured with a stop watch using a fixed point on the horizon with ship length to determine ship speed.

$b$. The arrival time of vessel drawdown at the known locations of the pressure cells and the capacitance gages allowed determination of speed between these points.

Table 7 shows ship speed determined from the pressure cells and from the bow to stern timing. 


\section{Design Ship in Existing and Proposed Waterway}

A design ship was needed to use in the HIVEL2D simulations to compare ship forces on the shoreline in the existing and proposed channels to address the first erosion scenario. The Galveston District wanted to use the ship that uses the channel most frequently and has the greatest forces at the shoreline. Based on data collected during the field experiments in 30 April-4 May 2002, ships were categorized according to beam width as less than $75 \mathrm{ft}, 75 \mathrm{ft}$ to less than $100 \mathrm{ft}$, $100 \mathrm{ft}$ to less than $125 \mathrm{ft}$, and equal to or greater than $125 \mathrm{ft}$. Frequency of occurrence during the field study is shown in Figure 5. The largest ships having beams of $125-150 \mathrm{ft}$ occurred most frequently and represented 38 percent of the 69 ships that used the channel during the field study. The actual range of ships' beams in the largest class is $129-142 \mathrm{ft}$.

Figure 6 shows ship speed versus ship beam at the south measurement site. Outbound ships are generally unloaded whereas inbound ships are loaded. A dependency of speed on ship size is shown in the figure. Figure 7 is a plot of ship drawdown measured during the field study versus ship beam at the south site. Drawdown is the maximum drop in water level below ambient during ship passage. Although the data are scattered due to different speeds and drafts, no significant difference in drawdown is shown for the two largest ship classes. This is a result of the 100-125-ft-beam ships traveling faster than the 125-150-ft-beam ships as shown in the speed versus ship beam plot in Figure 6. Figure 8 is a plot of ship surge measured during the field study versus ship beam. Surge is the maximum rise of the water level above ambient conditions during ship passage. Although the data are scattered due to different speeds and drafts, the expected increase in surge from the smaller, faster ships is present in the data. Figure 9 shows a plot of surge versus ship speed for the 125-150-ft-beam class that was previously shown to be the most frequent ship. The plot includes the ship draft by each data point and shows that the unloaded ships (draft about 28-30 ft) are the fastest and produce the largest surge. The conclusion of largest ship effects from the largest ships traveling unloaded is consistent with observations of Corps area office personnel at SNWW.

Based on the data presented herein, the ship using the channel most frequently is the largest class having beam widths of 125-150 ft. Most ships in this class are about $800 \mathrm{ft}$ in length and have beams of 129-142 ft. In this largest class, the loaded and unloaded ships produce about the same drawdown but the unloaded ships, because of their higher speeds, produce more surge. The design ship was selected to be $140-\mathrm{ft}$ beam by $800-\mathrm{ft}$ length with a $29-\mathrm{ft}$ draft typical of the unloaded ships.

\section{Larger Ship in Proposed Channel}

In addition to comparing the design ship in the existing and proposed channels (scenario 1), a larger ship that will use the proposed channel will be compared to the design ship in the existing waterway (scenario 2). Based on the simulator studies, a typical ship using the proposed channel is projected to be $899 \mathrm{ft}$ by $164 \mathrm{ft}$ by $48 \mathrm{ft}$ at maximum loaded condition. In the larger ship, ship 
effects will be evaluated for the unloaded condition, which is estimated to be a $30-\mathrm{ft}$ draft, and the 48-ft loaded draft.

\section{Observed Ship Speed in Existing Channel}

\section{South site}

For the ships observed during the field study, ships at the south site averaged 78 percent of their limit speed and ranged from 66 to 91 percent. Figure 10 shows speed at the south site versus cross-sectional area of the ship. Also shown are lines of 70, 80, 90, and 100 percent of computed limit speed. The channel width and area at the south site at a water level of $2.5 \mathrm{ft}$ mlt used in this computation were $740 \mathrm{ft}$ and $29,170 \mathrm{sq} \mathrm{ft}$, respectively, and exclude the shallow berm areas. Ships similar to the design ship were observed during the field study to travel at about 10 knots at the south site and is 86 percent of limit speed.

\section{North site}

Observed ship speeds at the north site are shown in Figure 11 and averaged 84 percent of the limiting speed. In the existing channel at the north site, the channel cross-section area at $2.5 \mathrm{ft}$ mlt excluding the shallow berms is $25,000 \mathrm{sq} f t$ which about 86 percent of the cross-section area at the south site. Water-surface width at the north site excluding berms is $670 \mathrm{ft}$.

\section{Simulator Speeds}

Based on the simulator report (Seamen's Church Institute 2002), the average speed for the $899-\mathrm{ft} \times 164-\mathrm{ft} \times 38$-ft ship in the existing channel was 6.2 knots (73 percent of limit speed). The same ship drafting $48 \mathrm{ft}$ in a $400-\mathrm{ft} \times 50$ - $\mathrm{ft}$ and $500-\mathrm{ft} \times 50$-ft alternative channels traveled at 6.3 and 6.9 knots, respectively (both are 75 percent of limit speed).

\section{Proposed Channel Cross-Section Characteristics}

\section{South site}

In the $700-\mathrm{ft} \times 50$ - $\mathrm{ft}$ proposed channel with $1 \mathrm{~V}: 2 \mathrm{H}$ side slopes, the channel area and water-surface width at a 2.5 -ft mlt water surface excluding shallow berms are $42,262 \mathrm{sq} f t$ and $910 \mathrm{ft}$, respectively.

\section{North site}

In the $400-\mathrm{ft} \times 50$ - $\mathrm{ft}$ proposed channel with $1 \mathrm{~V}: 2 \mathrm{H}$ side slopes and a barge lane, the navigation channel (not including barge lane) area and water-surface width at a 2.5 - $\mathrm{ft}$ mlt water surface are $28,760 \mathrm{sq} \mathrm{ft}$ and $670 \mathrm{ft}$, respectively. 


\section{Rules Used in Ship Speed Selection}

Rules used in establishing speeds were as follows:

a. Speeds at both north and south sites in the existing channel for the design ship were 85 percent of limit speed.

$b$. Speeds at both north and south sites in the proposed channel for the design ship will be between 80 and 85 percent of limit speed.

c. Speeds at both north and south sites in the proposed channels for the unloaded larger ship will be between 80 and 85 percent of limit speed.

d. Speeds at both north and south sites in the proposed channels for the loaded larger ship will be between 75 and 80 percent of limit speed. The reduced speed range for the loaded ship is due to the largest loaded ships in Figure 10 traveling at less than 80 percent of the limit speed.

Table 8 summarizes the speeds used in the two reaches and two ships for the existing and proposed channels in the HIVEL2D modeling. 


\section{HIVEL2D Simulations}

\section{Model Description}

The numerical model HIVEL2D (Stockstill and Berger 2001) is a finite element description of the two-dimensional (2-D) shallow-water equations in conservative form. The HIVEL2D model has been used for long period vessel effects from both shallow draft navigation (Stockstill and Berger 2001) and deepdraft navigation (Maynord 2000). ${ }^{1}$ The model is not applicable for determining short period waves from vessels. HIVEL2D was used to compare the effects of ships in the existing and after deepened channels using the two scenarios presented in Chapter 1. HIVEL2D was also used to determine the effects of ship speed restrictions in the deepened channel.

\section{Grid Refinement}

The long period drawdown produced by the ship has a wavelength of approximately the ship length or $700 \mathrm{ft}$. Sensitivity tests were run in a HIVEL2D study (Maynord, in preparation) in which the longitudinal elements describing the ship were 25, 50, and $100 \mathrm{ft}$ in length. Peak drawdown increased more than 20 percent when changing from 100-ft-long elements to 50-ft-long elements describing the ship. Peak drawdown increased 10 percent or less when changing from 50 -ft-long elements to 25 -ft-long elements describing the ship. The manner in which the boat shape is discretized also affects the selection of $25-\mathrm{ft}-, 50-\mathrm{ft}-$, or $100-\mathrm{ft}-1$-long longitudinal elements. At the bow, the draft of the boat changes from zero to full draft over the length of one element. Consequently longer elements result in a more gradual change in draft which is likely more representative of the streamlined shape of a typical ship. This fact favors selection of the longer elements. In the validation phase of this study and another study (Maynord, in preparation), good reproduction of field measured ship drawdown was obtained with $50-\mathrm{ft}-$ long elements describing the ship. The 50 -ft longitudinal cell length along the boat path was used in both the existing and after deepened channels.

\footnotetext{
1 Maynord, S. T. (2000). Letter report on vessel forces at Goat Islands restoration, Houston Ship Channel, prepared for U.S. Army Engineer District, Galveston.
} 


\section{Bathymetry Used in HIVEL2D Simulations}

Bathymetry at the north and south sites is shown in Figures 12 and 13 for the existing channel and Figures 14 and 15 for the proposed channels. Average cross sections at the north and south sites are shown in Figures 16 and 17 for the existing channel based on data collected during the field study.

\section{Pressure Field Representing Ship}

Along the boat path, the elements were $20-\mathrm{ft}$ wide by 50 - $\mathrm{ft}$ long. An important point to note is that the discretization of the grid and the sailing line establish the actual size of the boat being modeled. The specification of the region to experience the moving pressure field is shown in Figure 18. For the example shown in Figure 18, the sailing line was centered on the nodes. Any node within the bounded region in Figure 18 was subjected to the pressure drop. In the example shown in Figure 18, the free-surface pressure head was dropped equal to the boat draft at the sailing line node and at two nodes on either side of the sailing line. This results in a four-element-wide ship at the bottom of the ship. At the next node outside the last draft node, the free-surface pressure head is zero. Interpolations are made on the elemental level using bilinear functions. Therefore linear interpolation is made in directions parallel to a rectangular element's side. The use of rectangular elements to describe the vessel shape results in a linear distribution of free-surface pressure being imposed between the outermost draft node and the next water-level node. This pressure distribution gives the ship cross section a trapezoidal shape. (By the same procedure, the longitudinal cross section of the boat also has a trapezoidal shape.) This trapezoidal shape is four elements wide at the bottom and six elements wide at the water level giving an average width of five elements $\times 20 \mathrm{ft}=100 \mathrm{ft}$. This procedure results in the ability to model ship widths equal to odd multiples of the cell width $(100,140,180 \mathrm{ft})$ for a sailing line centered on the nodes and even multiples of the cell width $(80,120,160,200 \mathrm{ft})$ for a sailing line centered between the nodes.

One problem arises in using HIVEL2D when ship drafts approach channel depths. Depending on speed, channel size and ship size, the computed depth beneath the ship can tend to zero at which there is a singularity in the bed friction term and so the model will not run. In Maynord (2000), ${ }^{1}$ this problem of numerical instability occurred and various means of avoidance were tried in the model. This problem was solved by modeling a narrow deep ship with a wider shallow ship. Comparative runs were conducted with HIVEL2D in Maynord (2000) and similar drawdown and return velocity were obtained as long as the crosssectional area of the ship was maintained equal to the prototype. This same problem occurred in the SNWW simulations and a wider ship with lesser draft had to be used in some of the simulations. Problems did not occur for the unloaded design ship and a 140-ft beam was used. For the validation ship, Pacific Sapphire, having $137-\mathrm{ft}$ beam by $40-\mathrm{ft}$ draft, HIVEL2D would not run using a $40-\mathrm{ft}$ draft and the ship was modeled as $160-\mathrm{ft}$ beam by $34.25-\mathrm{ft}$ draft that

1 Maynord, S. T. (2000). op cit., p. 11. 
maintained the correct cross-sectional area. For the larger loaded ship having dimensions of $164-\mathrm{ft}$ beam by $48-\mathrm{ft}$ draft, the modeled ship was $200-\mathrm{ft}$ beam by 39.4-ft draft. For the larger unloaded ship having dimensions of 164- $\mathrm{ft}$ beam by 30 -ft draft, the modeled ship was $160-\mathrm{ft}$ beam by $30.75-\mathrm{ft}$ draft.

\section{Adjustment of Ship Speed to Account for Tidal Currents}

All HIVEL2D simulations in this study were conducted with slack water, i.e., without tidal velocities. This required that boat speeds be adjusted to simulate the correct speed of the ship through the water. Based on a tidal range of about $1.5 \mathrm{ft}$ at Mesquite Point, peak velocity in the numerical model of SNWW was about $1.5 \mathrm{ft} / \mathrm{sec}$ in the navigation channel. Tidal velocities were used to convert ship speed relative to ground to ship speed relative to water.

\section{Validation of HIVEL2D Using Existing Channel Data}

As stated previously, the Pacific Sapphire was selected as the ship to use in validation of the HIVEL2D model of the existing channel at both the north and south sites. The computational grids of the existing channel are shown in Figures 19 and 20 and contain 32,005 and 27,234 elements for the north and south sites respectively. The north and south site grids are 14 and 11 miles long. The center of the navigation channel was used to define the ship path in both the existing and deepened channels. The Pacific Sapphire was accelerated at $0.118 \mathrm{knots} / \mathrm{sec}$ until reaching a speed of 8.3 and 8.6 knots at the north and south sites, respectively. Water level used in the existing channel simulations was $3.16 \mathrm{ft}$ above mlt and was specified on the north boundary of the computational grid for the inbound Pacific Sapphire. Time-steps of $2 \mathrm{sec}$ were used in both validation simulations at the north and south sites. The turbulence coefficient was 0.25 and the $\alpha$ coefficient was 1.5 ( $\alpha=1$ specifies first order backward difference, $\alpha=2$ specifies second order backward difference, see Stockstill and Berger 1999). Manning's $n$ for all surfaces was 0.025 . Water levels were compared at the locations of the pressure cells and the capacitance gages as shown in Figures 21 to 24 . Figure 25 shows computed velocity for the outbound, unloaded Bornes because the velocity gage was not installed during passage of the Pacific Sapphire. Measured velocity for the Bornes is shown in Figure A11. Observed and computed values were in agreement and the HIVEL2D model was considered validated.

\section{HIVEL2D Simulations at South Site}

The design ship was run in the existing and proposed channels and the larger ship was run in the proposed channel at the speeds shown in Table 8 for the south site. Ambient water level for both channels and all runs was $2.5 \mathrm{ft}$ mlt. Figures 26-29 show contour plots of the water level and velocity for the design ship 
for the existing and proposed channels. Figures 30-33 show time-histories of water level and velocity magnitude at the shoreline, respectively at node 16002 which is at the location of the near-bank capacitance gage. The time-history of velocity magnitude in Figure 33 shows a negative spike in velocity which is at time $=690 \mathrm{sec}$ for the existing channel. This is the location of flow reversal from velocity opposite to the direction of ship travel before the spike to velocity in the same direction as ship travel after the spike. The flow reversal can be seen in the velocity vectors in Figures 27 and 29.

\section{HIVEL2D Simulations at North Site}

The design ship was run in the existing and proposed channels and the larger ship was run in the proposed channel at the speeds shown in Table 8 for the north site. Ambient water level for both channels and all runs was $2.5 \mathrm{ft}$ mlt. Figures 33-37 show contour plots of the water level and velocity for the design ship in the existing and proposed channels. Figures 38 to 41 show time-histories of water level and velocity at the shoreline at node 16952 (3582603, 13907953 are Easting, Northing State Plane coordinates) that is near the shoreline in the middle of the north site near pressure cell 350. Figure 42 shows time-history of water level at the shoreline at node $7953(3579443,13904643)$ to show variation of effects along the north site. This additional node was used at the north site because the shoreline is irregular as opposed to the uniform shoreline at the south site. 


\section{Surge and Transverse Stern Wave in Existing and Proposed Canals}

\section{Surge}

Based on the field observations, the TSW is the dominant loading on the bank and is used herein to quantify and compare the attack of the ship on the bank. The TSW is determined herein as the sum of the drawdown and surge. The HIVEL2D model is used to determine drawdown. Surge at the bank line depends on many factors that were not modeled in HIVEL2D including bank slope, bank height, etc. Surge calculations are given subsequently.

Dand and White (1978) studied surge wave formation on the Suez Canal which has a shallow berm adjacent to the navigation channel similar to SNWW. The surge waves of Dand and White are the TSW used herein. At a blockage ratio typical of the SNWW of 0.16, Dand and White found no wave disturbance below berm Froude number $F_{b}$ of 0.75 , undular waves for $F_{b}$ from 0.75 to 1.1 , and "broken water" for $F_{b}$ greater than 1.1. Berm Froude number is defined as

$$
F_{b}=\frac{V}{\sqrt{g h_{b}}}
$$

where

$$
\begin{aligned}
V & =\text { ship speed } \\
h_{b} & =\text { berm depth } \\
g & =\text { gravity }
\end{aligned}
$$

In the SNWW, berm Froude numbers at the south site for the field data ships were all greater than 0.75 and two-thirds of the ships had berm Froude numbers greater than 1.1.

The surge data from the field experiments for all ships were evaluated using dimensional analysis to develop an equation to estimate surge. The parameters that are likely to have an effect on the magnitude of surge height are 


$$
H_{s}=f\left(V, h_{b}, d, g, n\right)
$$

where

$$
\begin{aligned}
H_{s} & =\text { surge height } \\
d & =\text { drawdown } \\
n & =\text { blockage ratio }=\text { ship area/channel area }
\end{aligned}
$$

Dimensional analysis results in

$$
\frac{H_{s}}{h_{b}}=f\left(\frac{d}{h_{b}}, \frac{V}{\sqrt{g h_{b}}}, n\right)
$$

The second parameter on the right side of Equation 3 is the berm Froude number $F_{b}$ used by Dand and White (1978).

The SNWW data from the north and south sites were tested against the parameters in Equation 3. The blockage ratio $n$ in Equation 3 provided no improvement of the fit of the data and was omitted. Most of the variation in $H_{s} / h_{b}$ was explained by the berm Froude number with some improvement in the fit of the data with the addition of $d / h_{b}$. The best fit equation is

$$
\frac{H_{s}}{h_{b}}=0.22\left(\frac{d}{h_{b}}\right)^{0.6} F_{b}^{1.8}
$$

Equation 4 has an adjusted $\mathrm{R}$ squared of 0.58 . A design equation is used herein where the coefficient in Equation 4 is increased to 0.26 resulting in

$$
\frac{H_{s}}{h_{b}}=0.26\left(\frac{d}{h_{b}}\right)^{0.6} F_{b}^{1.8}
$$

The comparison of observed and predicted surge using Equation 5 is shown in Figure 43. The design Equation 5 provides some conservatism in the surge estimate and is used for all surge height determinations in this report.

\section{Transverse Stern Wave Comparison}

As stated previously, the TSW is used herein to quantify and compare bank forces and is equal to the drawdown from HIVEL2D and the surge height from Equation 5. The TSW is shown in Tables 9 and 10 for the existing and proposed channels for the design and larger ship at typical speeds in the existing channel 
and a range of speeds in the proposed channel. Typical speeds in the existing channel for the design ship are based on field observations and are equal to 85 percent of the computed limit speed of the channel. Speeds in the proposed channels are based on a range of speeds equal to 80-85 percent of limit speed for unloaded ships and 75-80 percent for loaded ships. It is important to note that basing speeds on percent of limit speeds results in increased speed in the proposed channel for the design ship. For example, at the south site, existing ships similar to the design ship typically travel at 10 knots ( 85 percent of limit). The same design ship is evaluated herein between 11.5 knots ( 80 percent of limit) and 12.2 knots ( 85 percent of limit) in the proposed channel.

One difference between the north and south sites shown in Tables 9 and 10 is the influence of speed increases. Change in speed at the south site results in changes in drawdown. For example, an increase of speed of the design ship from 11.5 knots to 12.2 knots results in an increase in drawdown from $3.55 \mathrm{ft}$ to $4.55 \mathrm{ft}$ at the south site (Table 9). At the north site, an increase of speed of the design ship from 9.6 knots to 10.2 knots results in an increase in drawdown from $3.0 \mathrm{ft}$ to $3.2 \mathrm{ft}$. The north site is located where the berm adjacent to the channel is much wider and also more shallow. The wider, more shallow berm has a significant effect on the wave characteristics at the shoreline.

From the TSW values in Table 9, under scenario 1, bank forces are worse in the proposed channel than in the existing channel for the design ship. TSW height under scenario 1 will increase at the south site from 7 to 39 percent and at the north site from 9 to 19 percent. The lower percentages of 7 and 9 percent indicate small impacts and the north at 9 percent being greater than the south at 7 percent is not a significant difference. The primary differences causing the lower values at the north site (19 percent versus 39 percent) results from two factors. First, the proposed channel size does not increase as much at the north site as at the south site. Second, the berm at the north site is wider and shallower than at the south site.

From the TSW values in Table 10, under scenario 2 bank forces are worse in the proposed channel than in the existing channel when comparing the larger ships in the proposed channel to the design ship in the existing channel. The larger unloaded ship creates larger TSW than the larger loaded ship (both in the proposed channel). This is consistent with observations in the existing channel. TSW height for the unloaded larger ship compared to the design ship under scenario 2 will increase at the south site 3 to 31 percent and at the north site 9 to 14 percent.

Table 11 shows the TSW height for the design ship in the existing and proposed channels at speeds close to the maximum for use in determining bank protection requirements. Values are based on ships traveling at 90 percent of limit speed which is recommended for design of bank protection in PIANC (1987). Transverse stern wave height should be used to design bank protection rather than velocity. The 3.4-ft surge for the proposed ship at the south site is a significant extrapolation of Equation 5 and must be viewed as approximate. 


\section{Speed Restrictions in Proposed Channel}

One of the objectives of this study was to evaluate the effects of speed restrictions in the proposed channel. The speed restriction evaluation has two parts. The first part is to determine speeds in the proposed canal that will result in the same ship forces on the bank as in the existing canal. The second part is to determine speeds in the proposed canal that will result in various levels of reduced ship forces compared to the existing canal. Both parts can only be achieved if speeds in the proposed channel are less than the speeds used previously in this report and shown in Table 8. As in the previous portion of this report, the TSW will be used to quantify and compare the various ship speeds in existing and proposed channels.

The first step is to determine typical speeds in the existing canal for all ships. To describe ship size, the simplest parameter that describes ship effects is the ship area that is equal to beam multiplied times average draft. Neither length nor beam nor draft alone properly describes the size effects of the ship. Consideration was given to using a tonnage but this parameter may be more difficult to define for an unloaded ship than simply beam time draft. The design ship used in the earlier part of this report traveled at about 85 percent of limit speed in the existing channel at both the north and south sites. When considering all ships and both sites, ships in the SNWW travel at about 80 percent of limit speed (see Figures 10 and 11). Figure 44 shows speeds at 80 percent of limit speed for both sites at a range of ship areas. As an example, a 39-ft draft ship having a beam of $106 \mathrm{ft}$ has a ship area of $39 \times 106=4,134 \mathrm{sq} \mathrm{ft}$. Based on Figure 44, the $106-\mathrm{ft}$ beam $\times 39-\mathrm{ft}$ draft ship travels at an average speed of 8.4 knots in the Sabine-Neches Canal (north site). Figure 44 can only be used with beam and draft in feet and speed in knots.

The next step is to determine ship forces in the existing canal using the typical speeds shown in Figure 44. Three ship areas along the speed curves in Figure 44 were used in the speed evaluations of the existing channel as shown in Table 12. Note that some of the ships were modeled with wider, lesser drafts to prevent run problems discussed previously. As stated previously, use of a wider, less draft ship in the HIVEL2D model has negligible impact on the drawdown as long as the correct ship area is maintained. Using the Table 12 ships and the speeds from Figure 44, HIVEL2D simulations were conducted to determine the drawdown in the existing channel. Equation 5 was used to determine surge in the 
existing channel. Drawdown and surge were summed to provide the TSW and results are shown in Table 13 at the south site and Table 14 at the north site.

The next step is to determine ship speeds in the proposed canal that result in the same TSW that occurs in the existing canal. This step requires modeling various speeds for each ship size to find the speed that gives the same TSW height in the existing and the proposed canals. This step is straightforward except for ships that do not presently travel in the existing canal such as the $900-\mathrm{ft}$ $\times 164-\mathrm{ft} \times 48$-ft ship proposed to use the deepened canal. This ship represents one of the largest ships in the proposed waterway. The target TSW height for this size ship will be set equal to the TSW height from the largest ships in the existing waterway. Based on Tables 13 and 14, the target TSW height for the largest ships in the proposed canal are $3.6 \mathrm{ft}$ at the south site and $3.1 \mathrm{ft}$ at the north site.

Results of the various HIVEL2D simulations and Equation 5 for the proposed canals are shown in Tables 15 and 16 at the south and north sites respectively. Using TSW heights in the existing channel from Tables 13 and 14, speed in the proposed channel giving the same TSW was interpolated from Tables 15 and 16. Results are plotted in Figures 45 and 46 for equal TSW at the south and north sites, respectively. Also shown are the speeds evaluated for the design ship $(810 \mathrm{ft} \times 140 \mathrm{ft} \times 29 \mathrm{ft})$, the larger loaded ship $(900 \mathrm{ft} \times 164 \mathrm{ft} \times 48 \mathrm{ft})$, and the larger unloaded ship $(900 \mathrm{ft} \times 164 \mathrm{ft} \times 30 \mathrm{ft})$. Note that the speeds evaluated and the restricted speeds for the larger loaded ship are about the same. This results from the assumption stated previously that the largest loaded ship in the proposed channel will have the same TSW as the largest loaded ship in the existing channel. At the south site, equal TSW height is achieved when ships travel about 1.2 to 1.5 knots faster in the proposed channel than in the existing channel. At the north site, equal TSW height is achieved when ships travel about 0.3 to 0.5 knots faster in the proposed channel than in the existing channel. The lesser increase at the north site is due to the smaller change in cross-section size in the proposed channel.

Figure 47 and 48 show speeds required in the proposed channel to achieve TSW height of 75 percent and 50 percent of the TSW height in the existing channel.

Figures 45-48 show that the SNWW ships operate in speed ranges where small changes in speed make large changes in TSW. This results primarily from two factors. First, the ships are operating at a large percentage of their limit speed. Second, the shallow berm amplifies drawdown, surge, and thus TSW. 


\section{Summary and Conclusions}

The SNWW is a confined navigation channel with a shallow berm adjacent to the navigation channel whose berm width varies from near zero to more than $800 \mathrm{ft}$ in the Sabine-Neches Canal. Confined channels are those in which the ship cross-sectional area is large compared to the channel cross-sectional area, being as much as 20 percent at SNWW. In this comparison of ship effects before and after enlargement of the channel, ship speed is the most critical and most difficult parameter to define. Confined channels have a limiting speed that cannot be exceeded by a self-propelled ship. The limit speed primarily depends on ship area relative to channel area. At SNWW, ships are traveling at 66-95 percent of their limit speeds. As a ship's speed nears the limit speed, the shallow berm and fast ship speed result in a large breaking wave forming adjacent to the shoreline. This wave, referred to herein as the transverse stern wave (TSW), moves at the ship speed and has a magnitude of up to $5.5 \mathrm{ft}$ based on measurements reported herein and is calculated to be up to $8.4 \mathrm{ft}$ for extremely fast ships in the proposed channel. The TSW is used herein to quantify and compare ship effects on the shoreline.

To evaluate ship effects, a north site was used to represent the Sabine-Neches Canal and a south site to represent the Port Arthur Canal. The Sabine-Neches Canal is proposed to be deepened to $50 \mathrm{ft}$ while remaining at the current $400 \mathrm{ft}$ bottom width. The Port Arthur Canal is proposed to be deepened to $50 \mathrm{ft}$ and bottom width increased from 500 to $700 \mathrm{ft}$.

HIVEL2D is a 2-D numerical model that was used herein to calculate the long period ship drawdown at SNWW. The model was validated using data from one of the ships measured during the field data collection portion of this study.

The TSW is equal to the drawdown, the fall below the ambient level, plus the surge, the rise above the ambient level. The field data collected for this study was used to develop an equation for surge based on ship speed, berm depth, and drawdown.

Two scenarios were evaluated that have the potential for increased bank attack in the proposed channel. The first scenario is that ships currently using the SNWW will be able to travel faster in the larger proposed channel resulting in an increase in bank attack. The first scenario is evaluated by comparing TSW in existing and proposed channels using a design ship having dimensions of $810 \mathrm{ft}$ $\times 140 \mathrm{ft} \times 29 \mathrm{ft}$. This design ship was chosen because it has a high frequency of passage in the existing SNWW and it creates some of the largest TSW in the 
existing SNWW. The second scenario is that future ships will be larger than those using the existing SNWW and will cause larger bank attack. Scenario 2 is evaluated by comparing TSW in the existing channel using the design ship having dimensions of $810 \mathrm{ft} \times 140 \mathrm{ft} \times 29 \mathrm{ft}$ to TSW in the proposed channel using a larger $900 \mathrm{ft} \times 164 \mathrm{ft} \times$ loaded (48-ft draft) and unloaded (30-ft draft) ship.

The two bank attack scenarios were evaluated using speeds equal to 85 percent of limit speed for the design ship in the existing channels, speeds ranging from 80-85 percent of limit speed for the design ship and larger unloaded ship in the proposed channels, and speeds ranging from 75-80 percent of limit speed for the larger loaded ship in the proposed channels.

Results show that at the lower end of the range of speeds evaluated in the proposed channels, the TSW will increase in height less than 10 percent for both bank attack scenarios in both the Port Arthur and Sabine-Neches Canals. At the upper end of the range of speeds evaluated in the proposed channels, the TSW will increase an average of 35 percent in the Port Arthur Canal and an average of 17 percent in the Sabine-Neches Canal for both bank attack scenarios. The lesser change in the Sabine-Neches Canal is due to the smaller increase in cross section and the wider berm.

Speed restriction tests were conducted with the proposed channel to determine speeds that will (a) result in equal TSW in the existing and proposed channels and (b) lessen TSW in the proposed channel compared to the existing channel. In the Port Arthur Canal, equal TSW is achieved when ships travel about 1.2 to 1.5 knots faster in the proposed channel than in the existing channel. In the Sabine-Neches Canal, equal TSW is achieved when ships travel about 0.3 to 0.5 knots faster in the proposed channel than in the existing channel.

All of the results herein show that ships in the existing and proposed SNWW are operating at speeds where small changes in speed make large changes in TSW. This results primarily from two factors. First the ships are operating at a large percentage of their limit speed. Second, the shallow berm amplifies drawdown, surge, and thus TSW. 


\section{References}

Dand, I. W., and White, W. R. (1978). "Design of navigation canals." Proceedings of Delft Symposium on Aspects of Navigability of Constraint Waterways, Including Harbour Entrances, The Netherlands.

Herbich, J. B., Schiller, R. E., and Kim, K. (1979). "Bank erosion along the Sabine Neches Waterway, Progress Report No. 1," prepared for State Department of Highways and Public Transportation, Beaumont District by Texas A\&M University.

Herbich, J. B., and Schiller, R. E. (1984). "Surges and waves generated by ships in a constricted channel," Coastal Engineering - 1984.

Maynord, S. T. (1996). "Return velocity and drawdown in navigable waterways," Technical Report HL-96-7, U.S. Army Engineer Waterways Experiment Station, Vicksburg, MS.

Maynord, S. T. (in preparation). "Ship effects before and after deepening of the Tolchester Channel, Chesapeake Bay, Maryland," U.S. Army Engineer Research and Development Center, Vicksburg, MS.

PIANC. (1987). "Guidelines for the design and construction of flexible revetments incorporating geotextiles for inland waterways," Supplement to Bulletin 57, Permanent International Association of Navigation Congresses, Brussels.

Seaman's Church Institute. (2002). "Sabine-Neches improvement study, ship simulation study," Contract No. DACW42-01-R-0010, prepared for U.S. Army Engineer Research and Development Center, Vicksburg, MS.

Stockstill, R. L., and Berger, R. C. (1999). "A two dimensional flow model for vessel-generated currents," ENV Report 10, U.S. Army Engineer Research and Development Center, Vicksburg, MS. . (2001). "Simulating barge drawdown and currents in channel and backwater areas," Journal of Waterway, Port, Coastal, and Ocean Engineering, American Society of Civil Engineers 127(5), 290-298. 


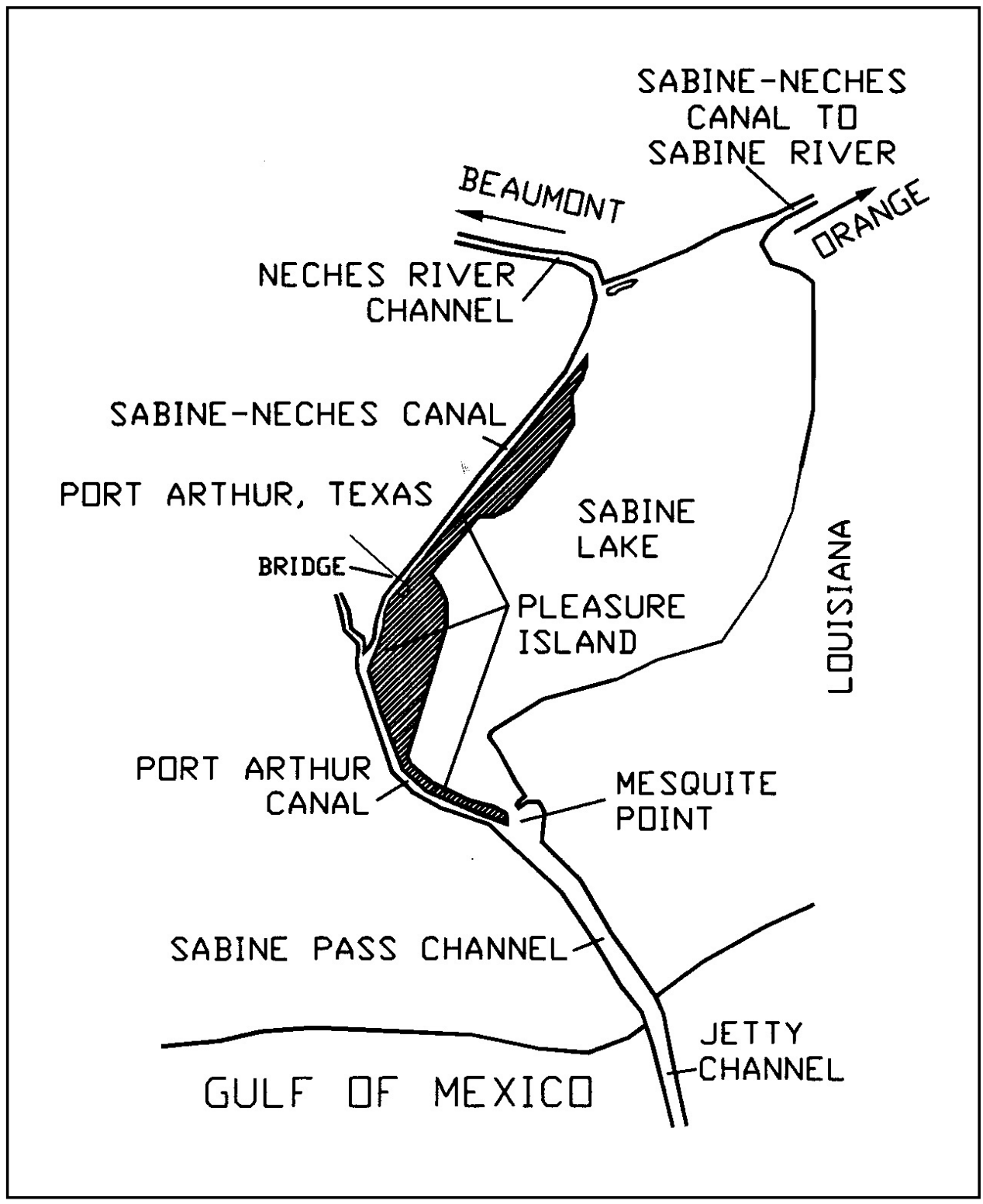

Figure 1. Sabine-Neches Waterway 


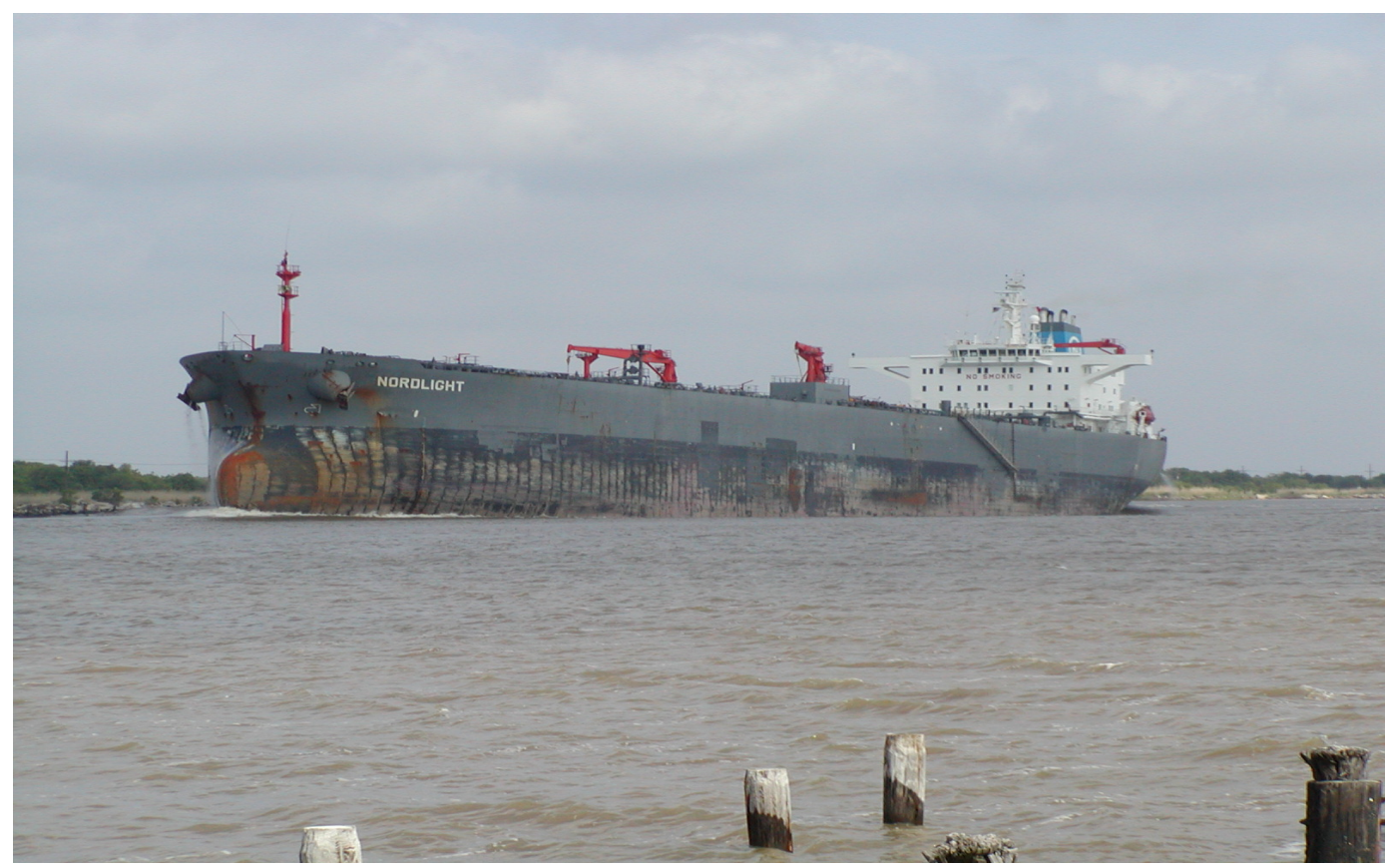

a. $801 \mathrm{ft}$ by $138 \mathrm{ft}$ by $30 \mathrm{ft}$, outbound, 10.3 knots

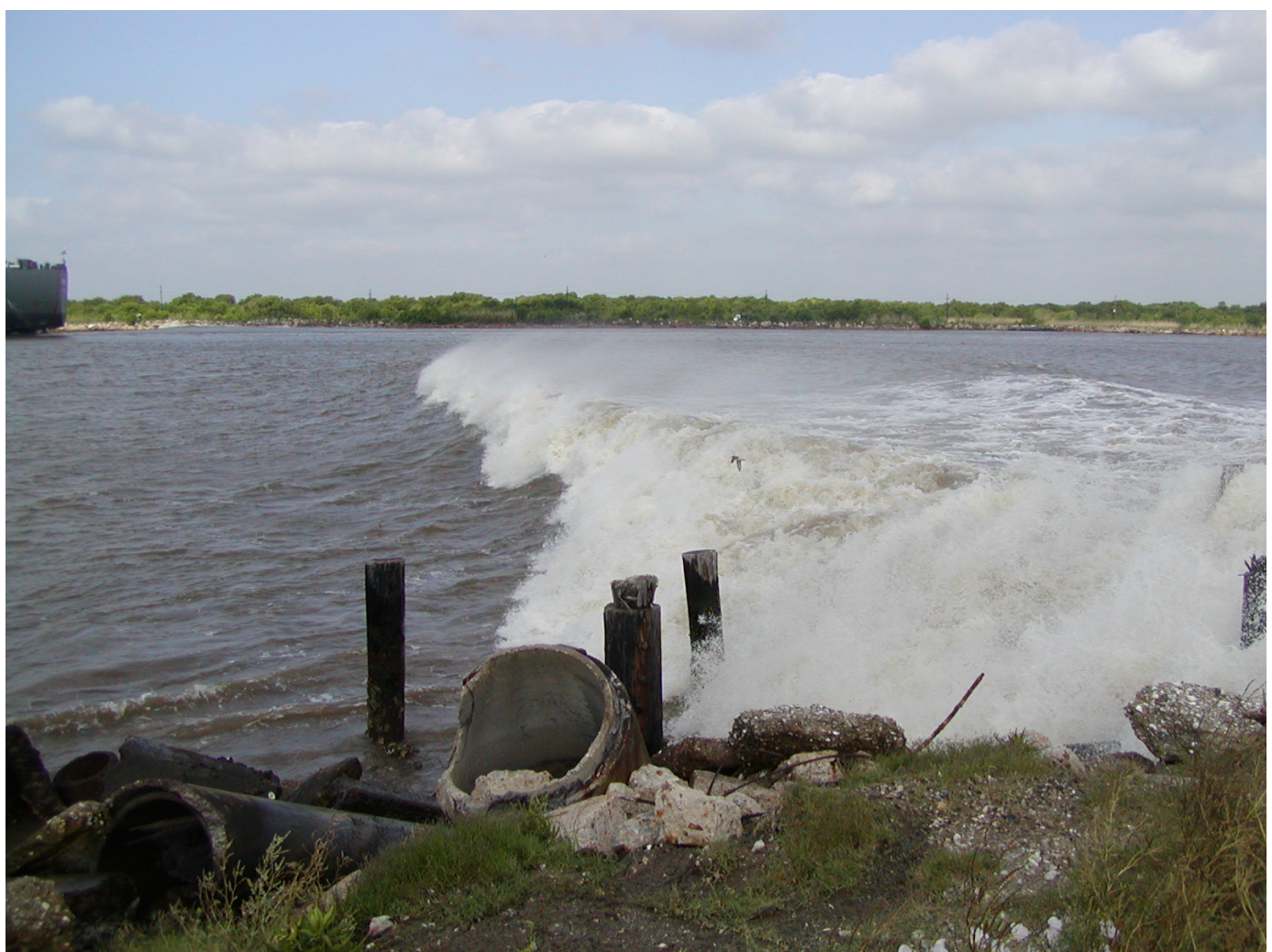

b. Transverse stern wave from Nordlight

Figure 2. Nordlight in Port Arthur Canal 


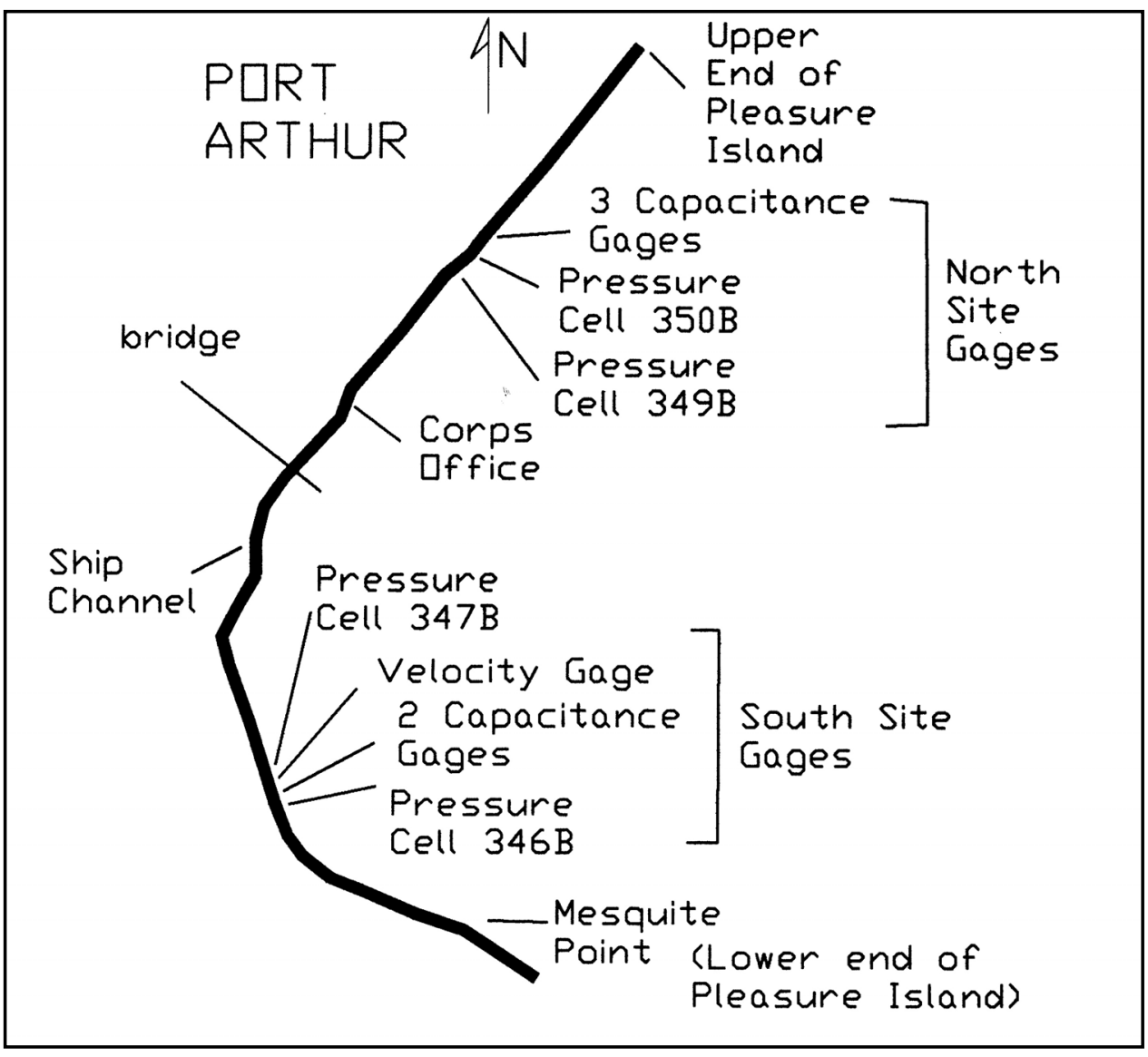

Figure 3. Schematic of SNWW south site, north site, and gage locations 


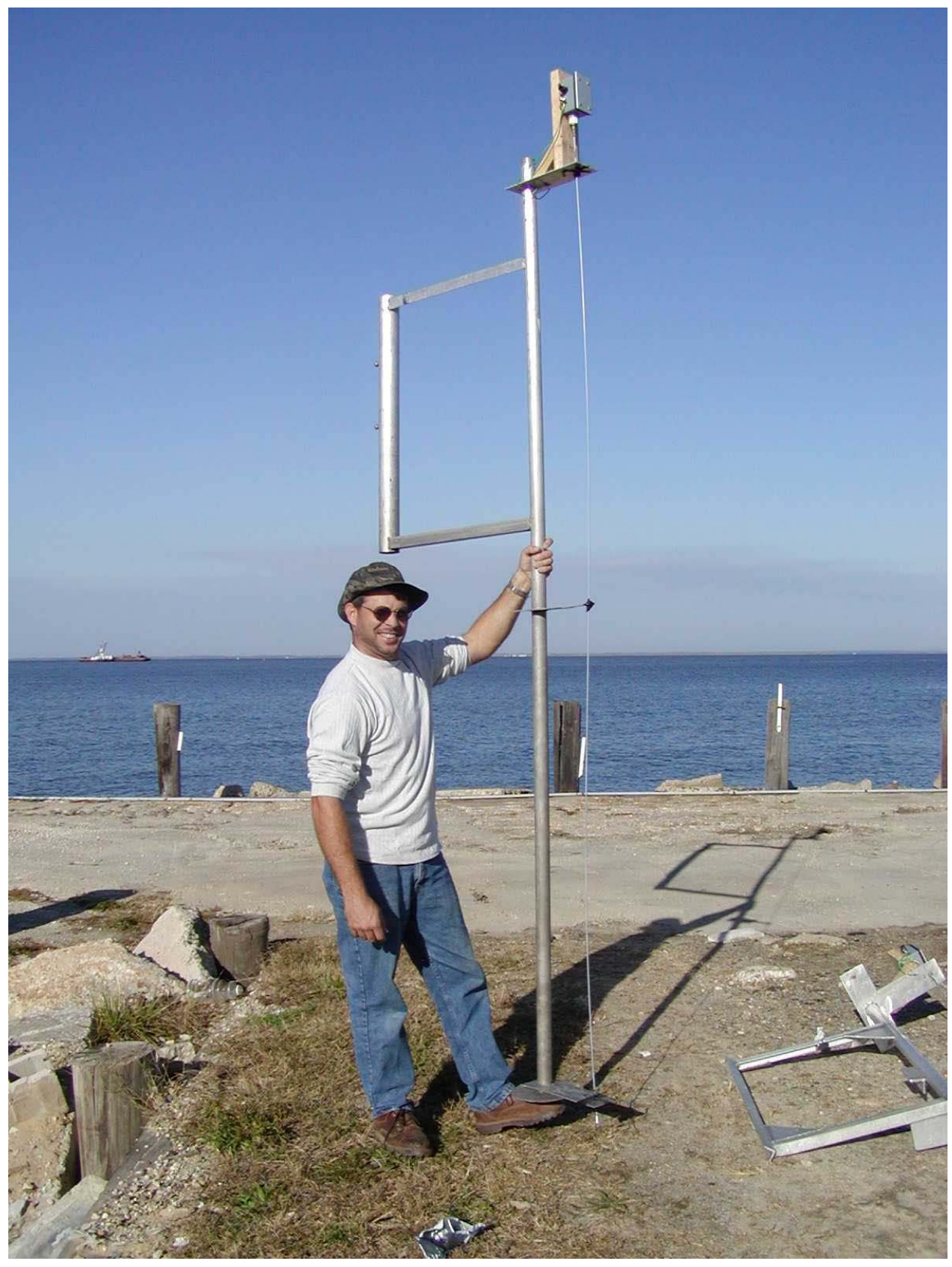

Figure 4. Capacitance water level gage and mount 


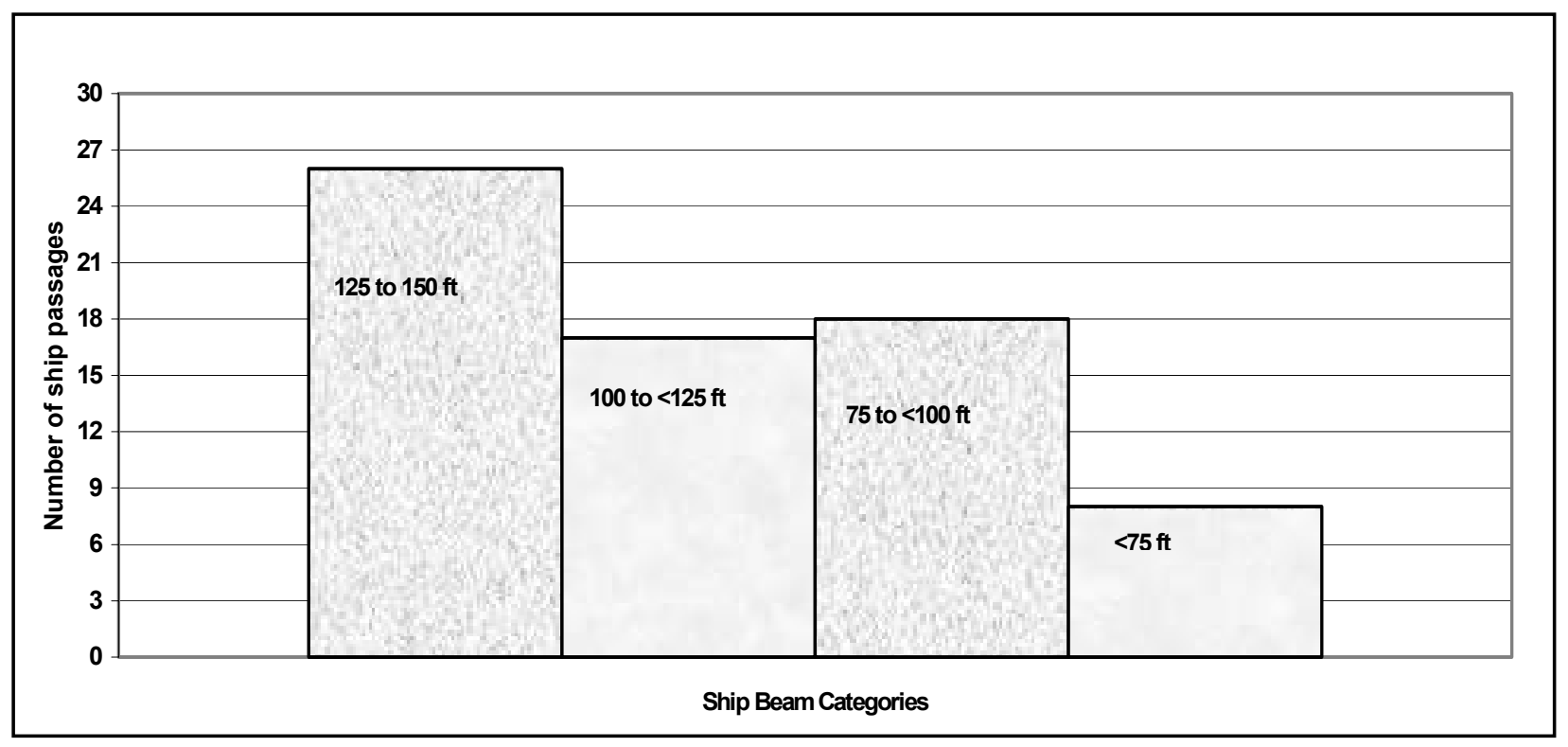

Figure 5. Ship frequency versus ship beam during $30 \mathrm{Apr}-4$ May 2002 field study

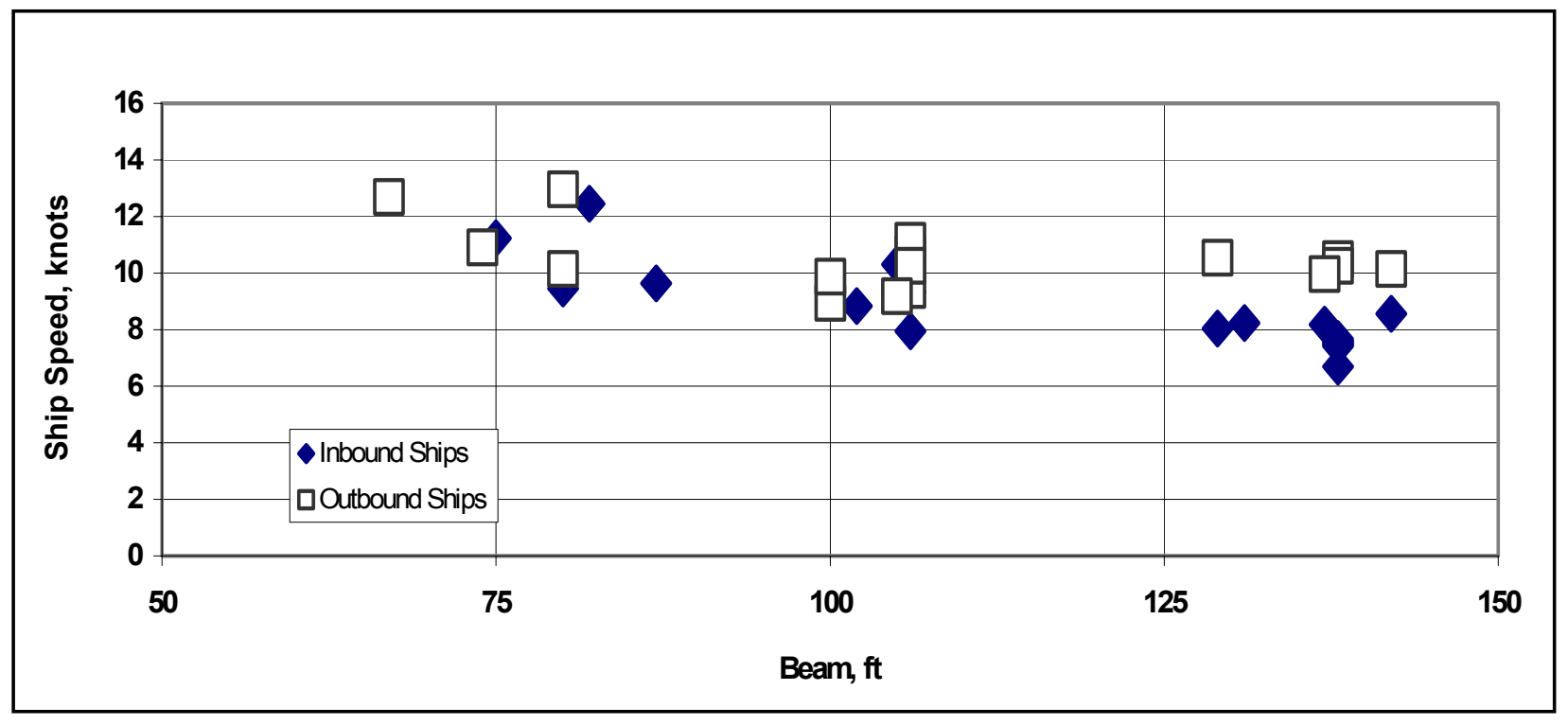

Figure 6. Observed ship speed versus ship beam, south site 


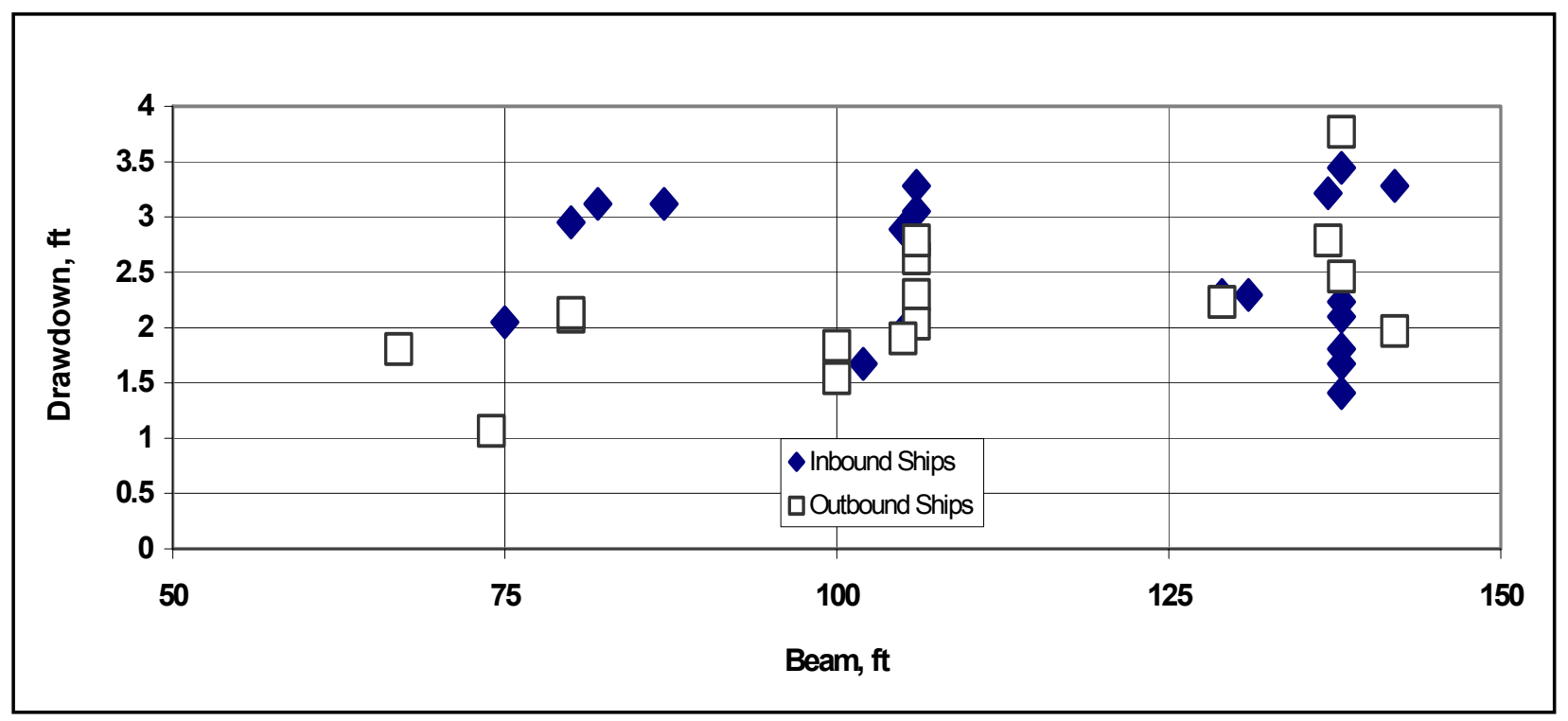

Figure 7. Observed drawdown versus ship beam, south site

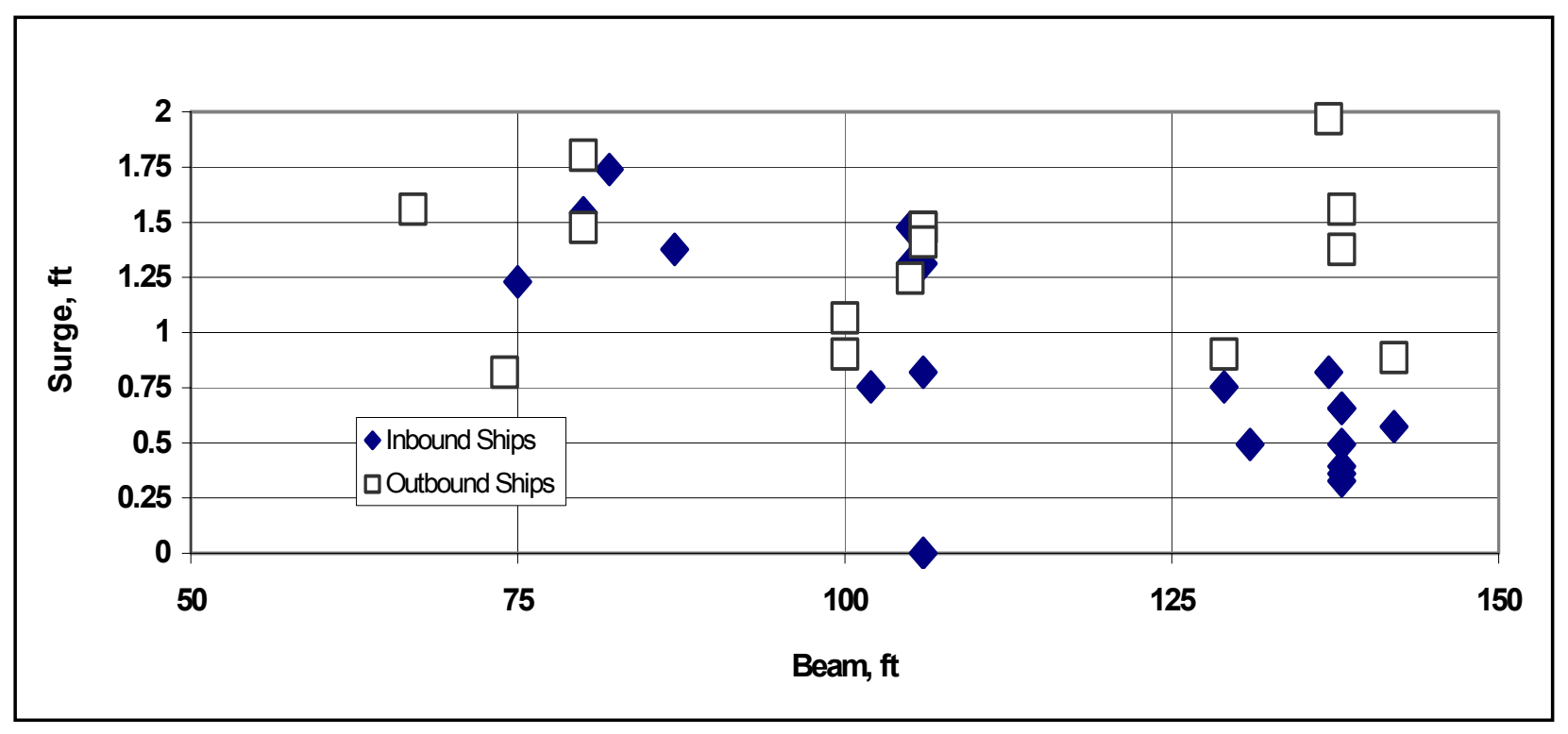

Figure 8. Observed surge versus ship beam, south site 


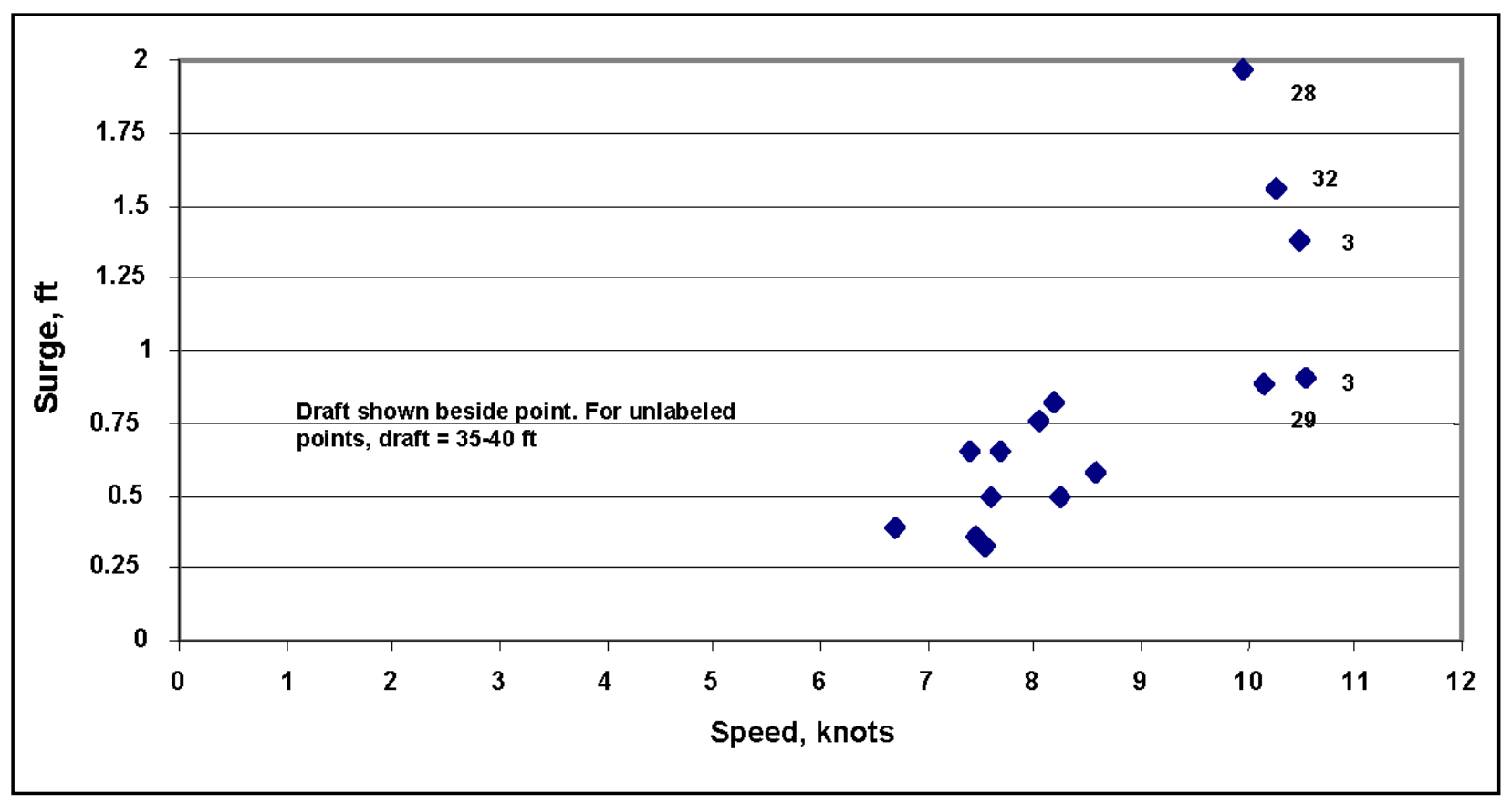

Figure 9. Observed surge versus ship speed, 125-150-ft-beam ships, south site

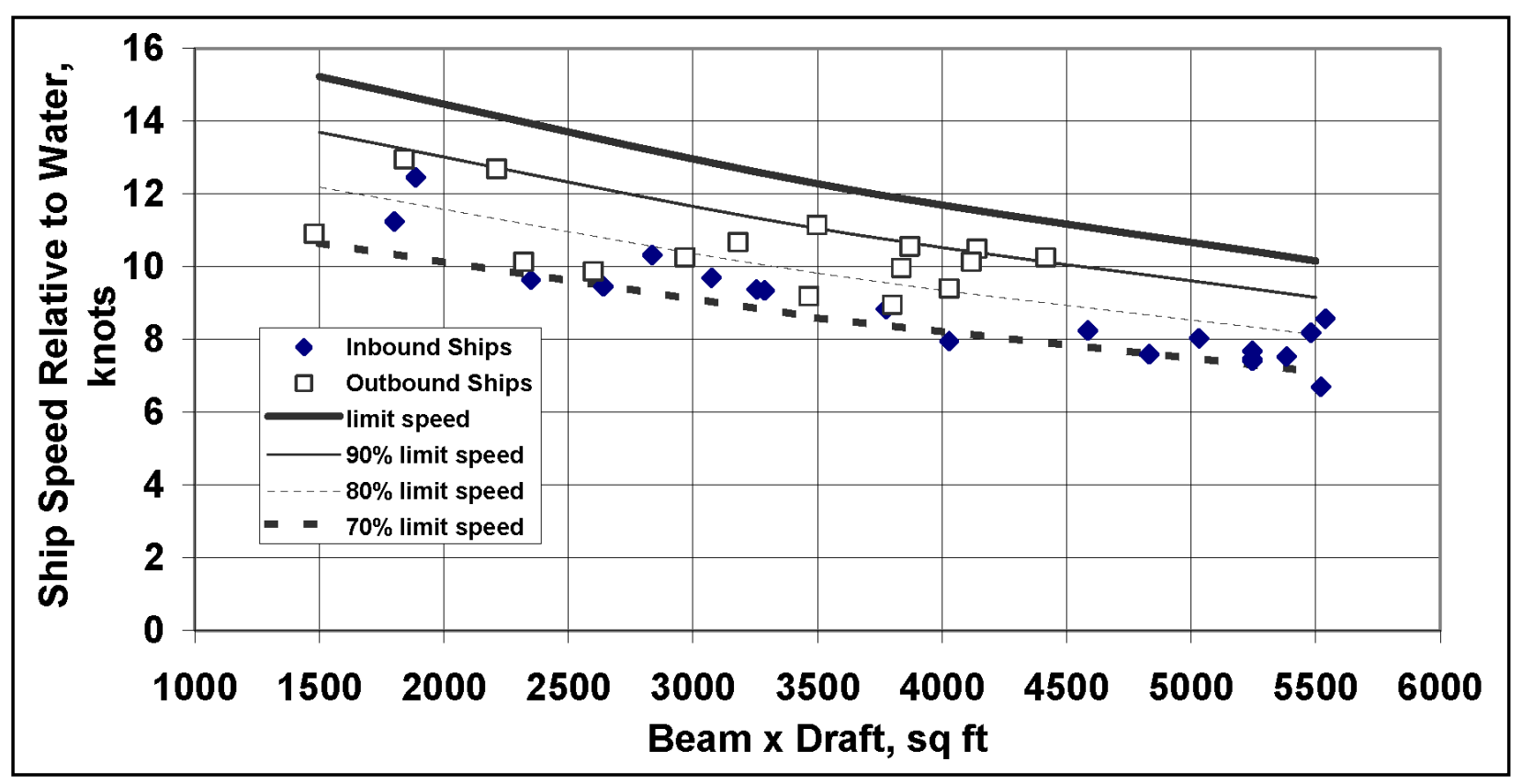

Figure 10. Ship speed versus beam $\times$ draft, south site 


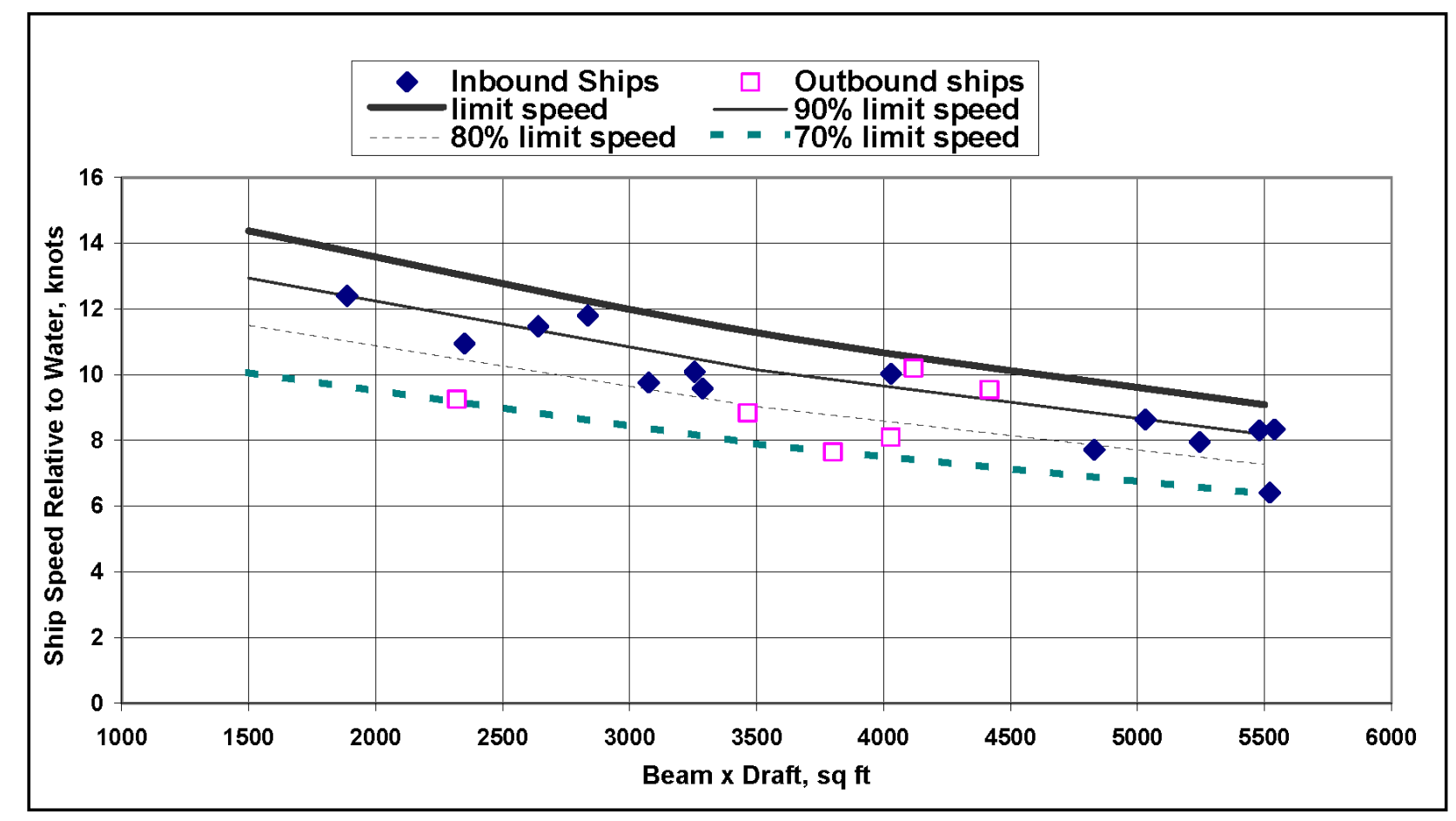

Figure 11. Ship speed versus beam $\times$ draft, north site

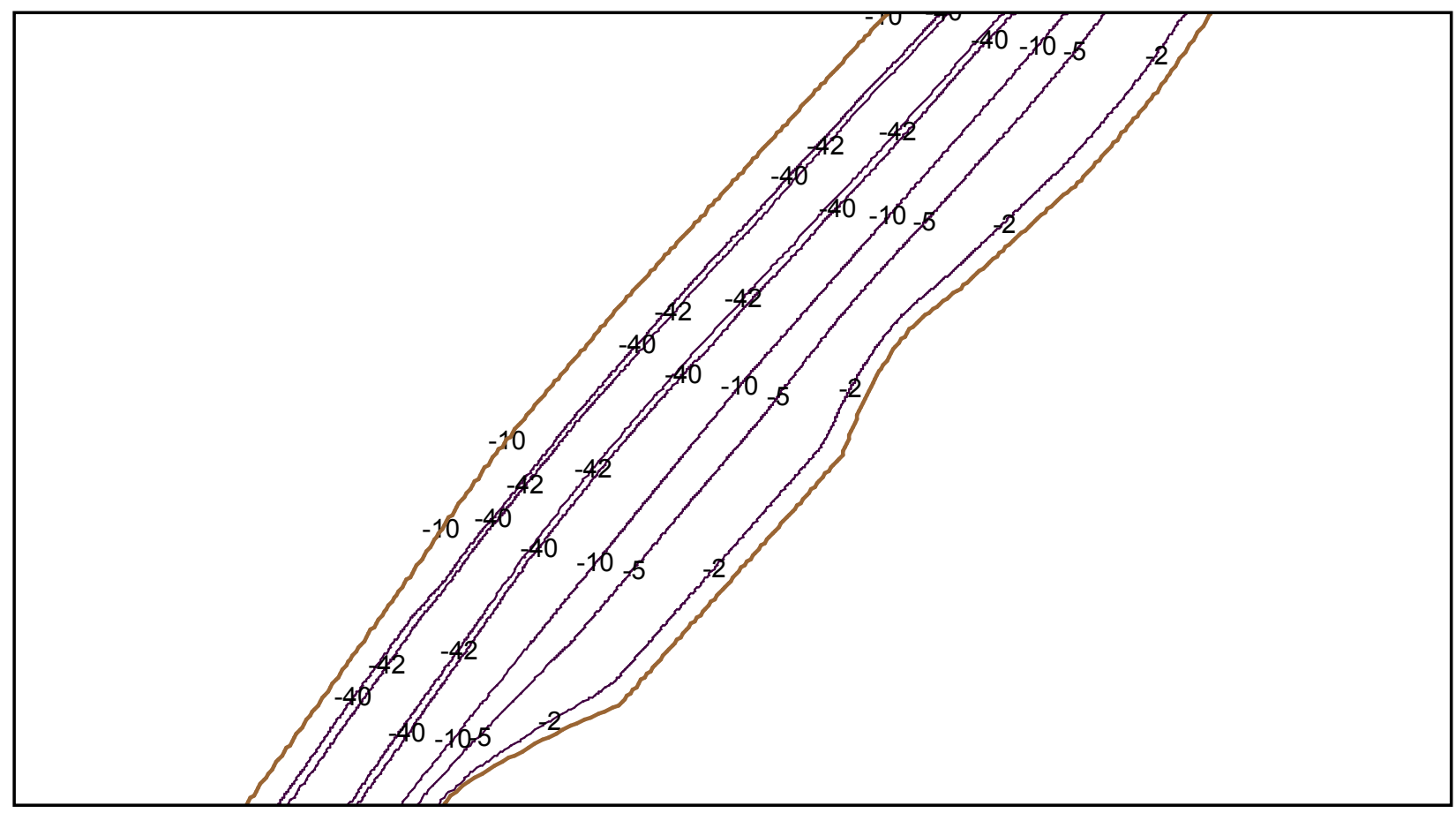

Figure 12. Bathymetry, north site, existing channel, contours are feet below mlt 


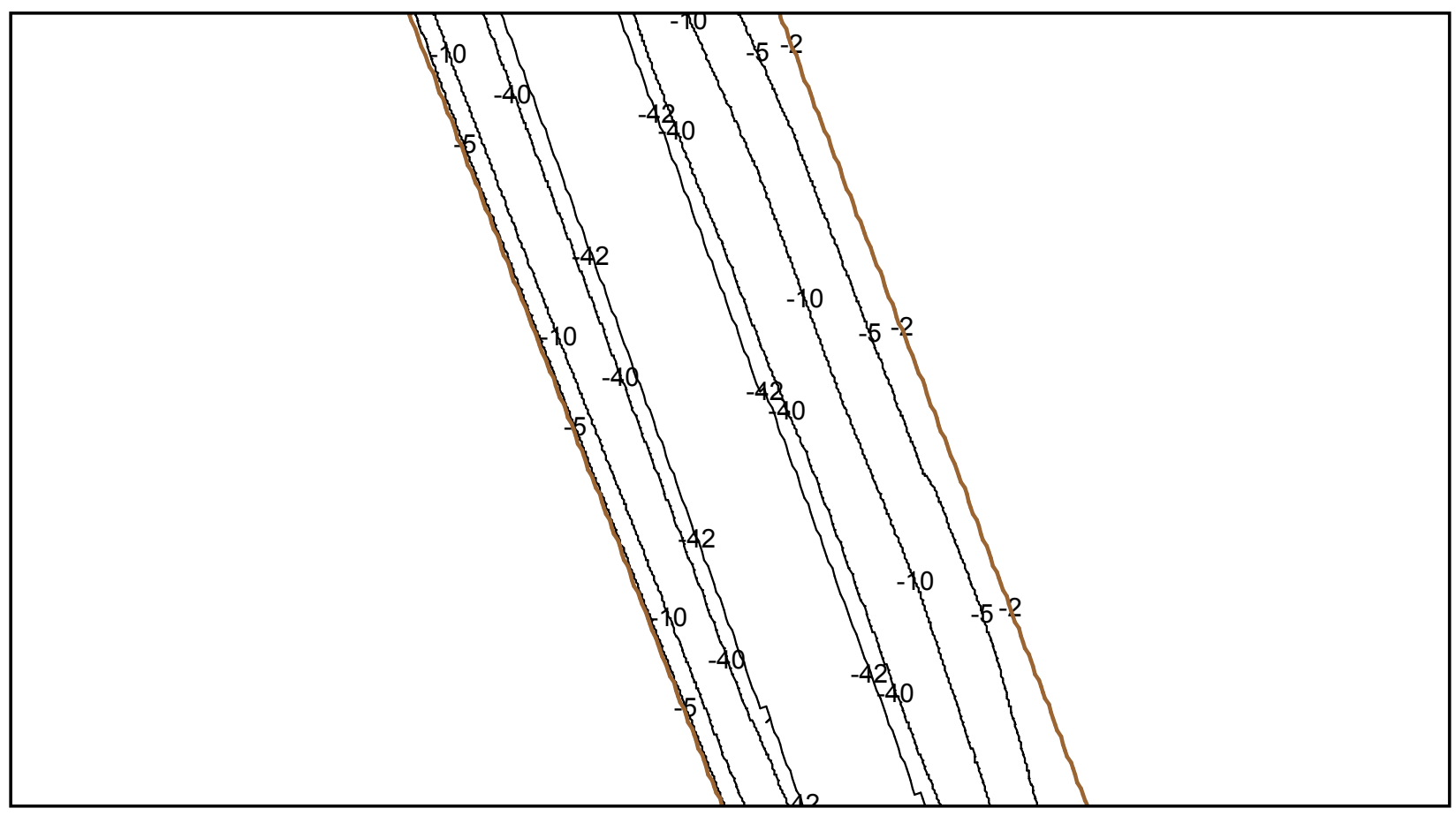

Figure 13. Bathymetry, south site, existing channel, contours are feet, mlt

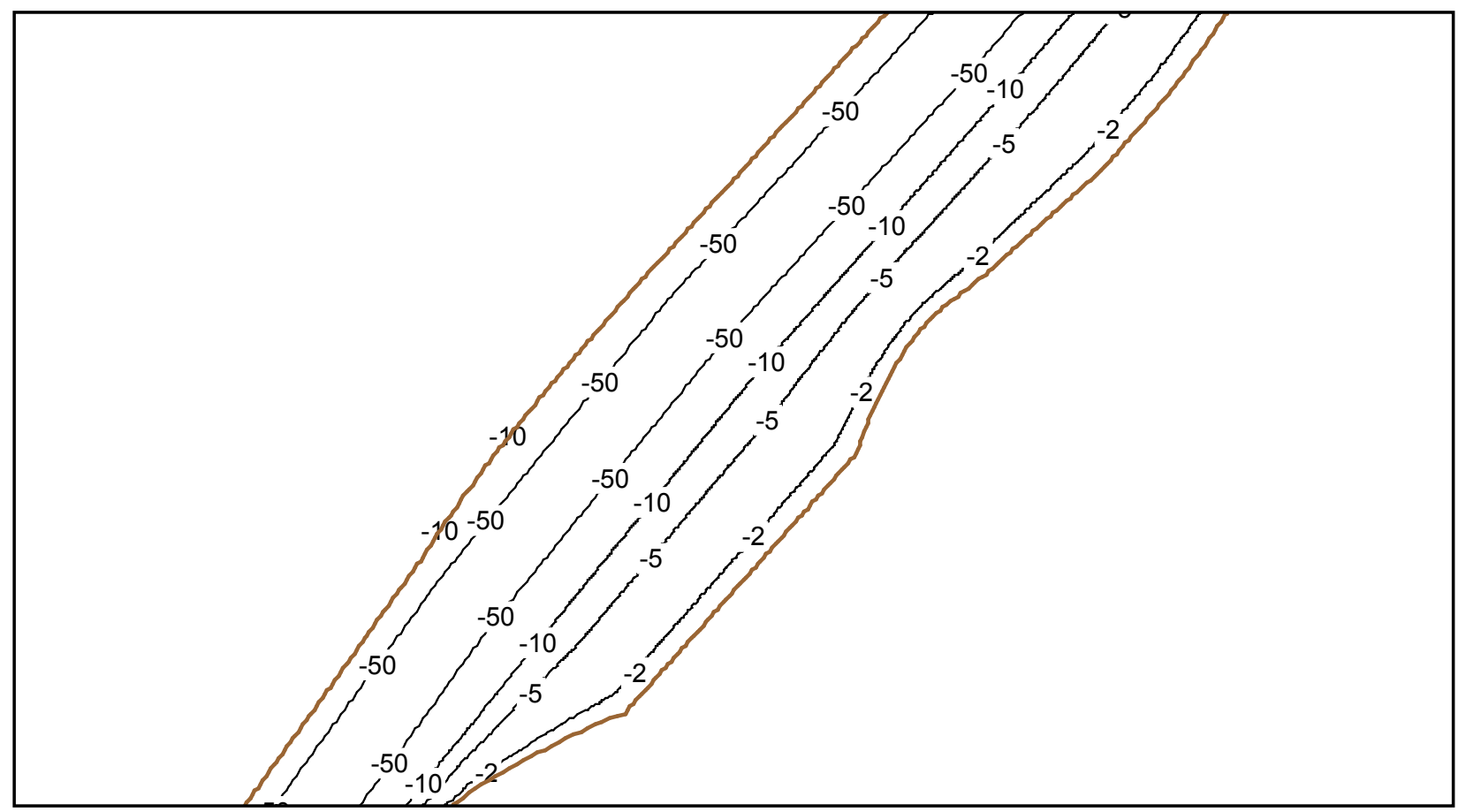

Figure 14. Bathymetry, north site, proposed channel, contours are in feet, mlt 


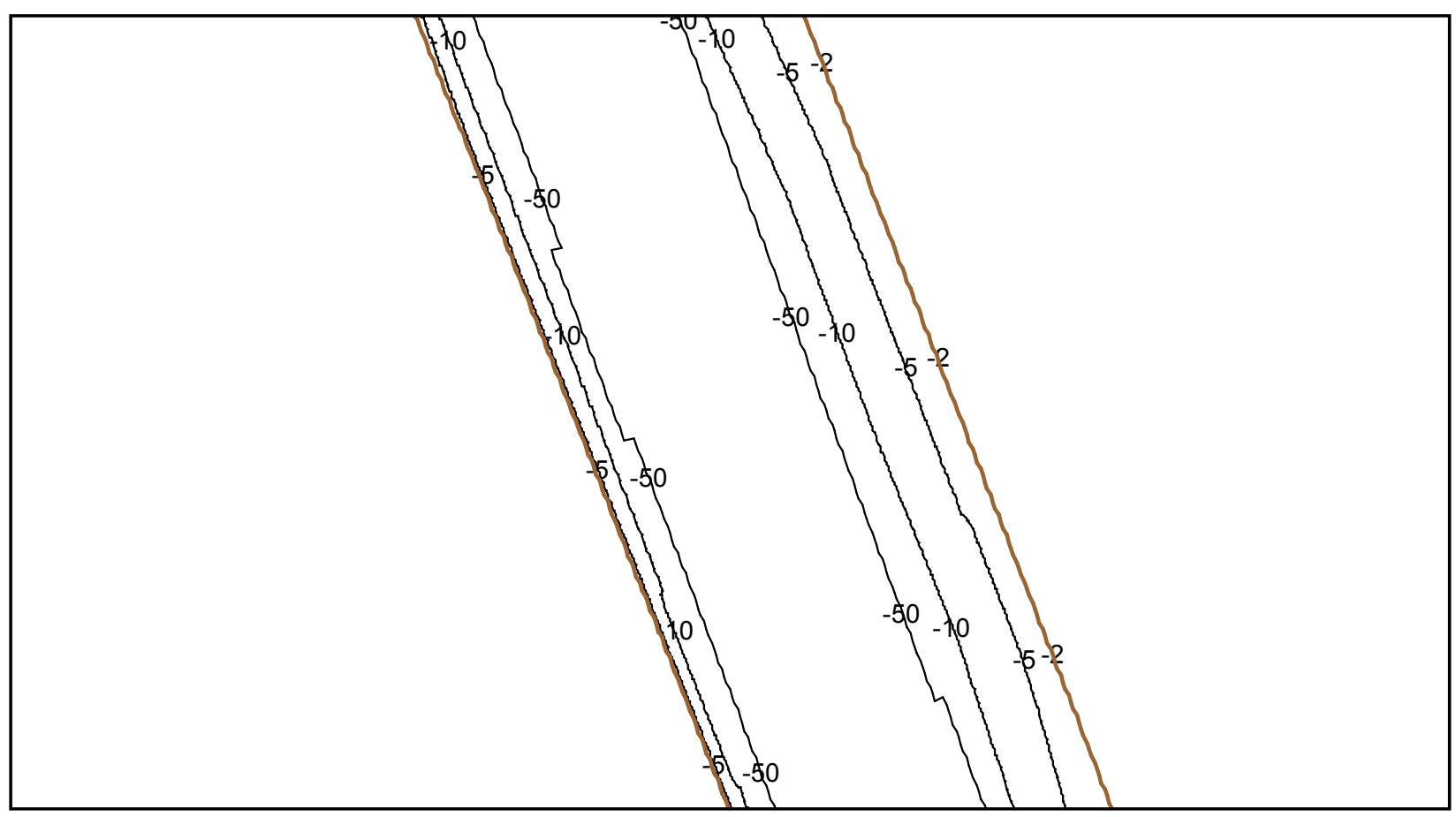

Figure 15. Bathymetry, south site, proposed channel, contours are feet, mlt

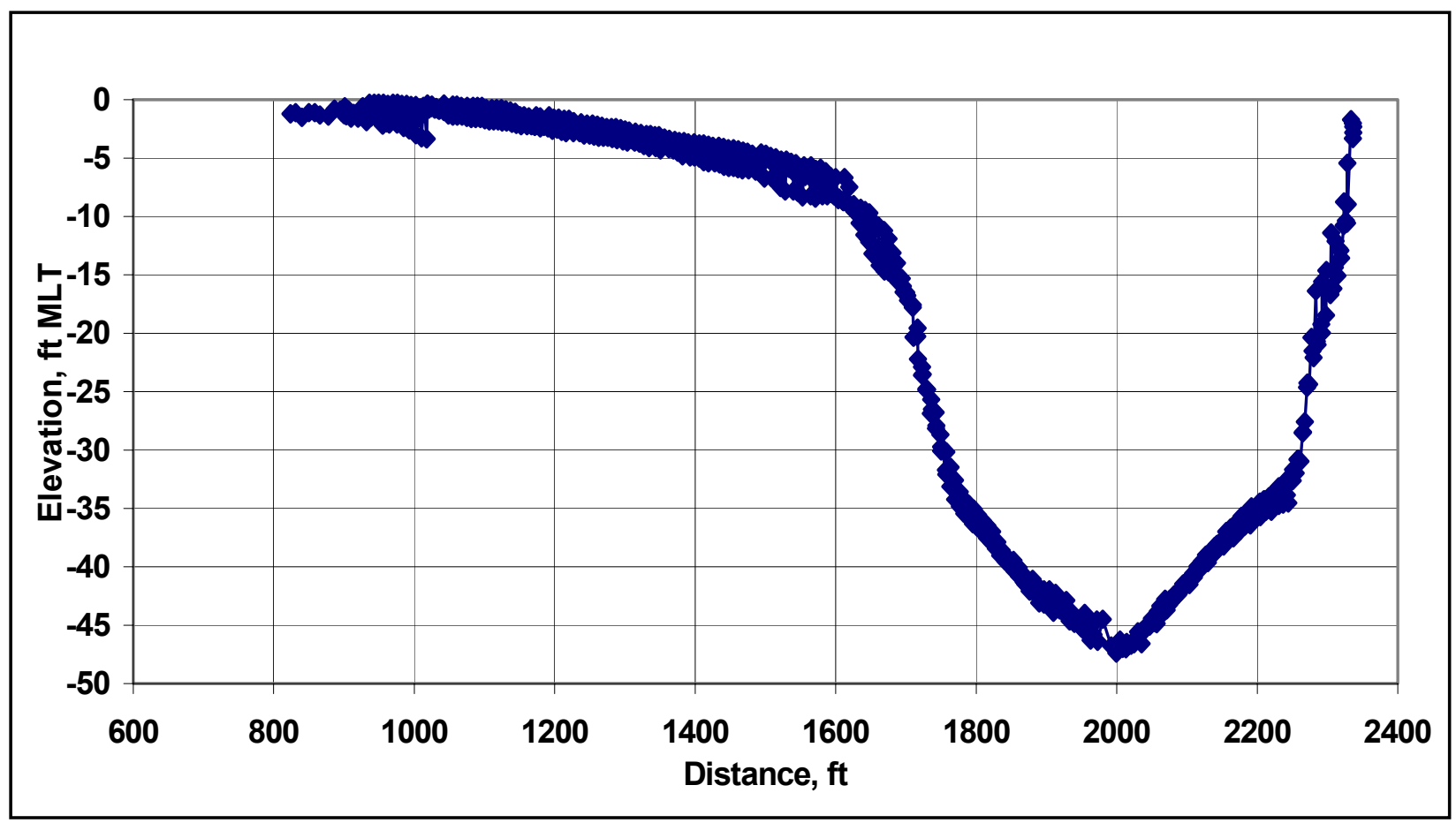

Figure 16. Cross section at north site of existing channel 


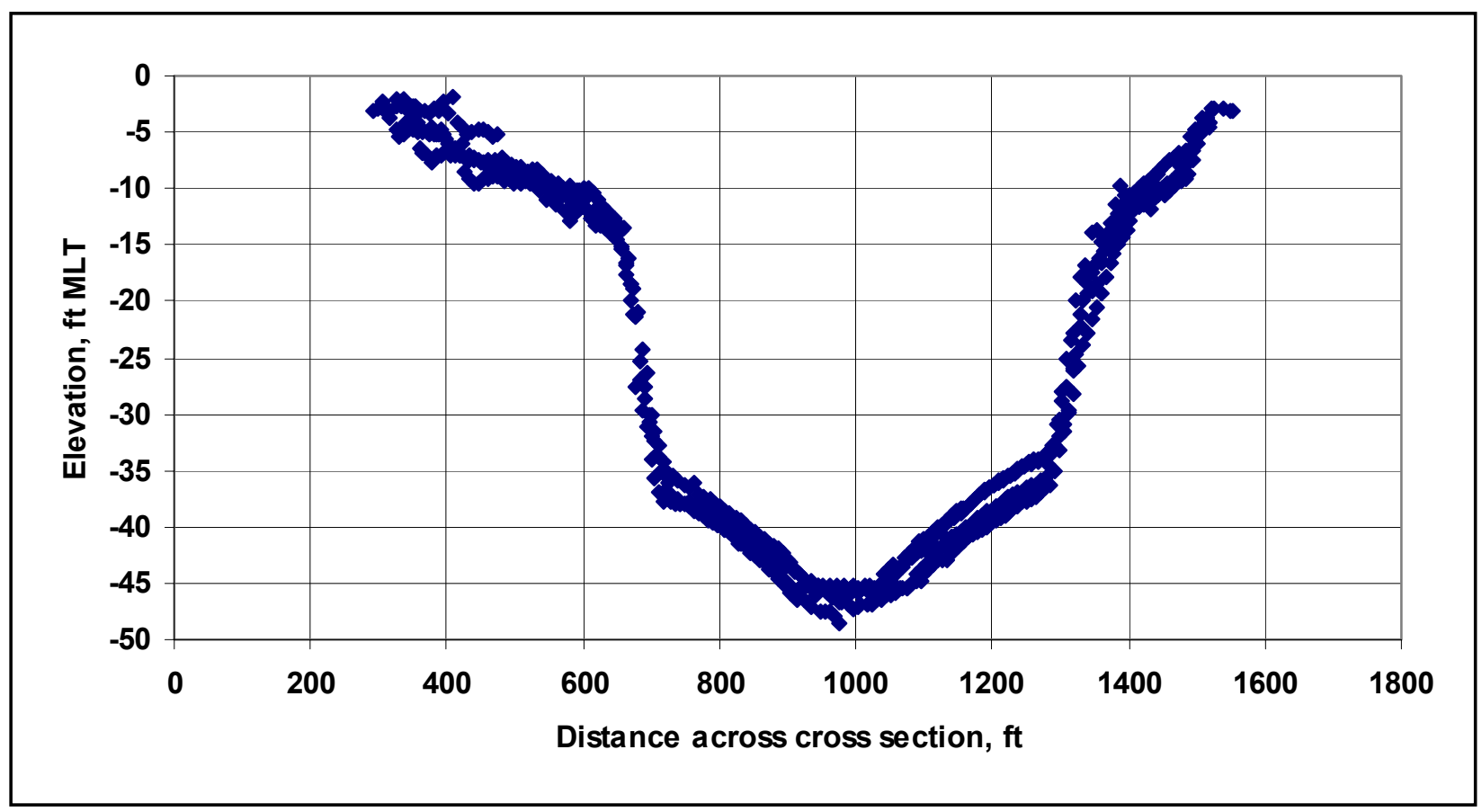

Figure 17. Cross section at south site of existing channel

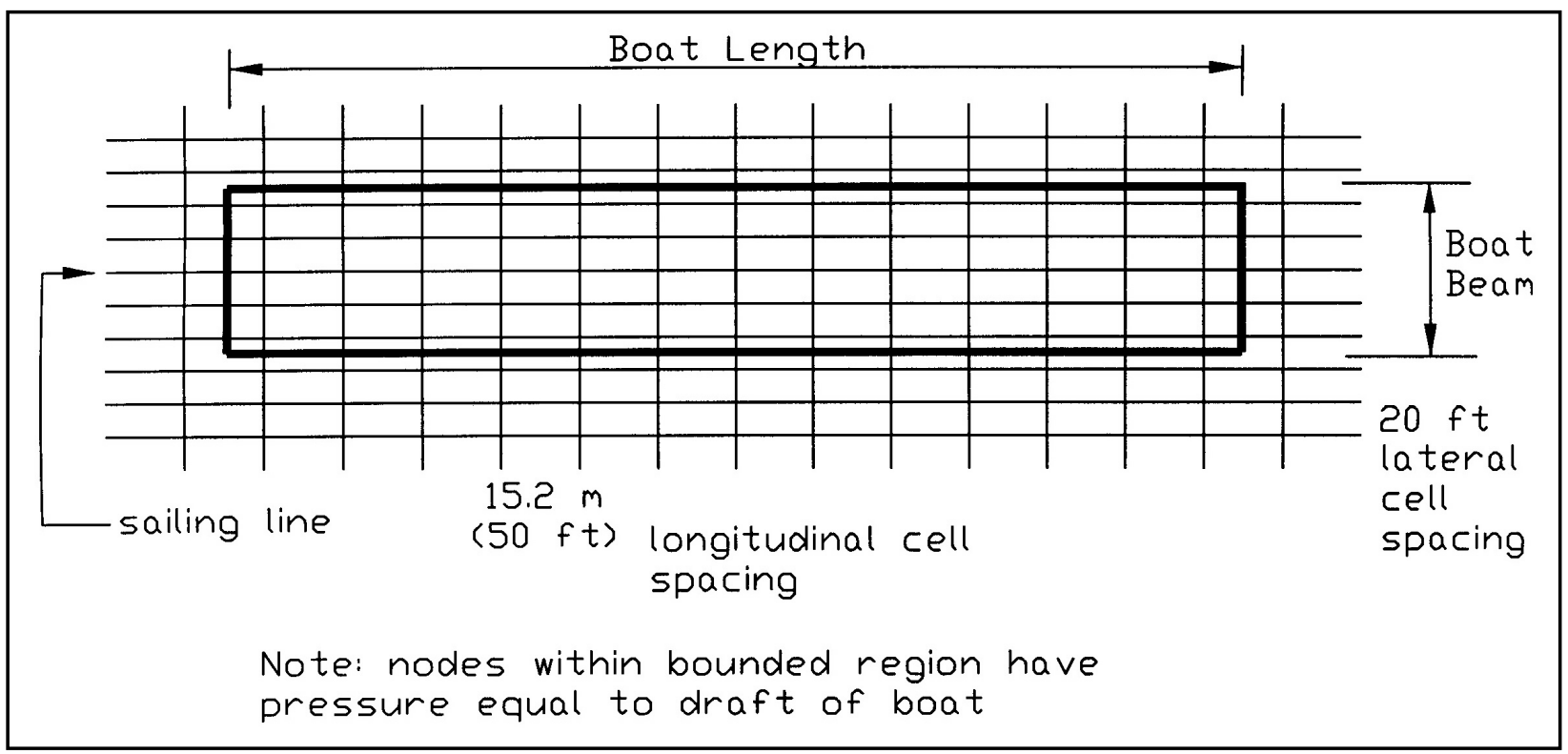

Figure 18. Pressure field representing ship 


$$
\frac{1}{k}
$$




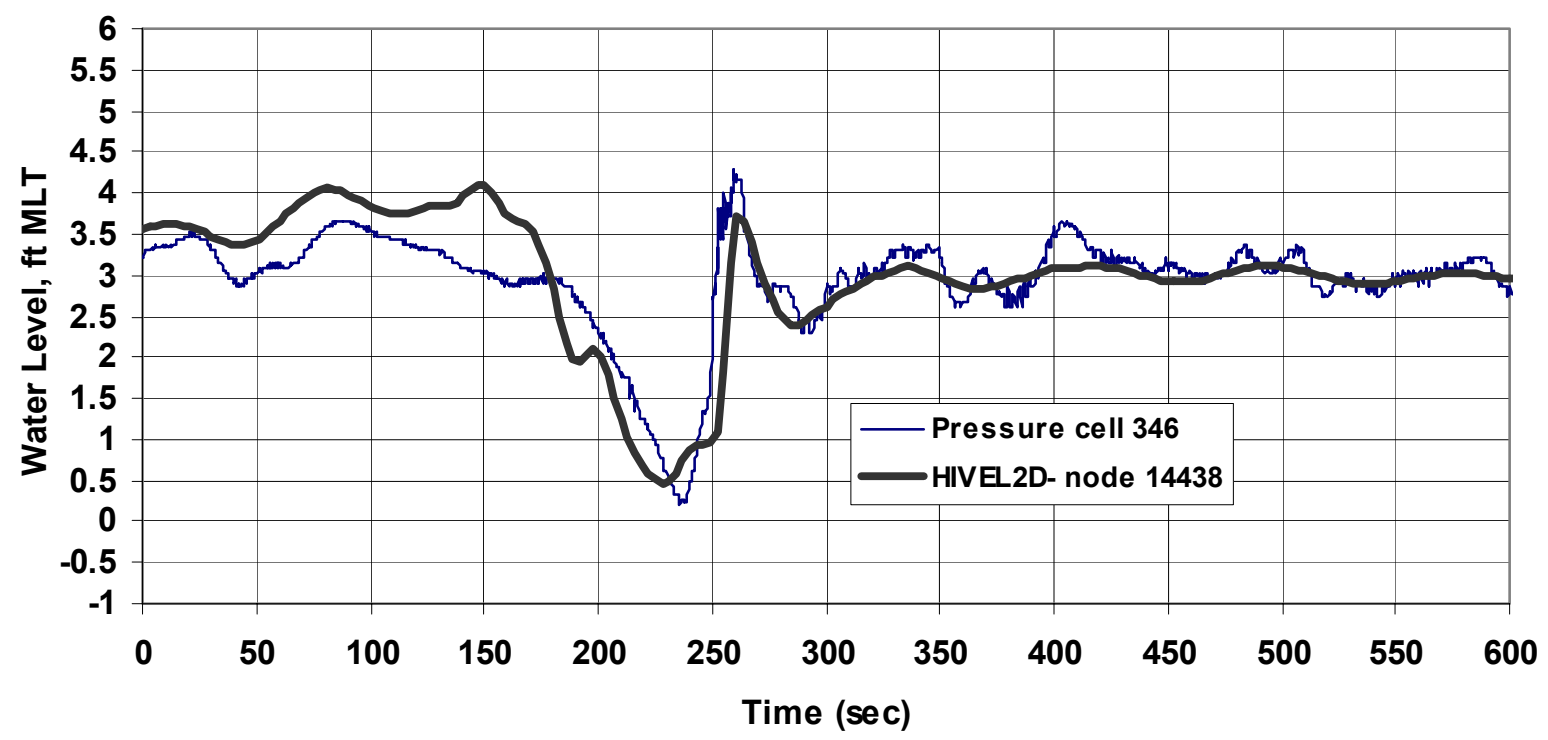

Figure 21. Observed and HIVEL2D water level for Pacific Sapphire at pressure cell 10346, south site, existing channel

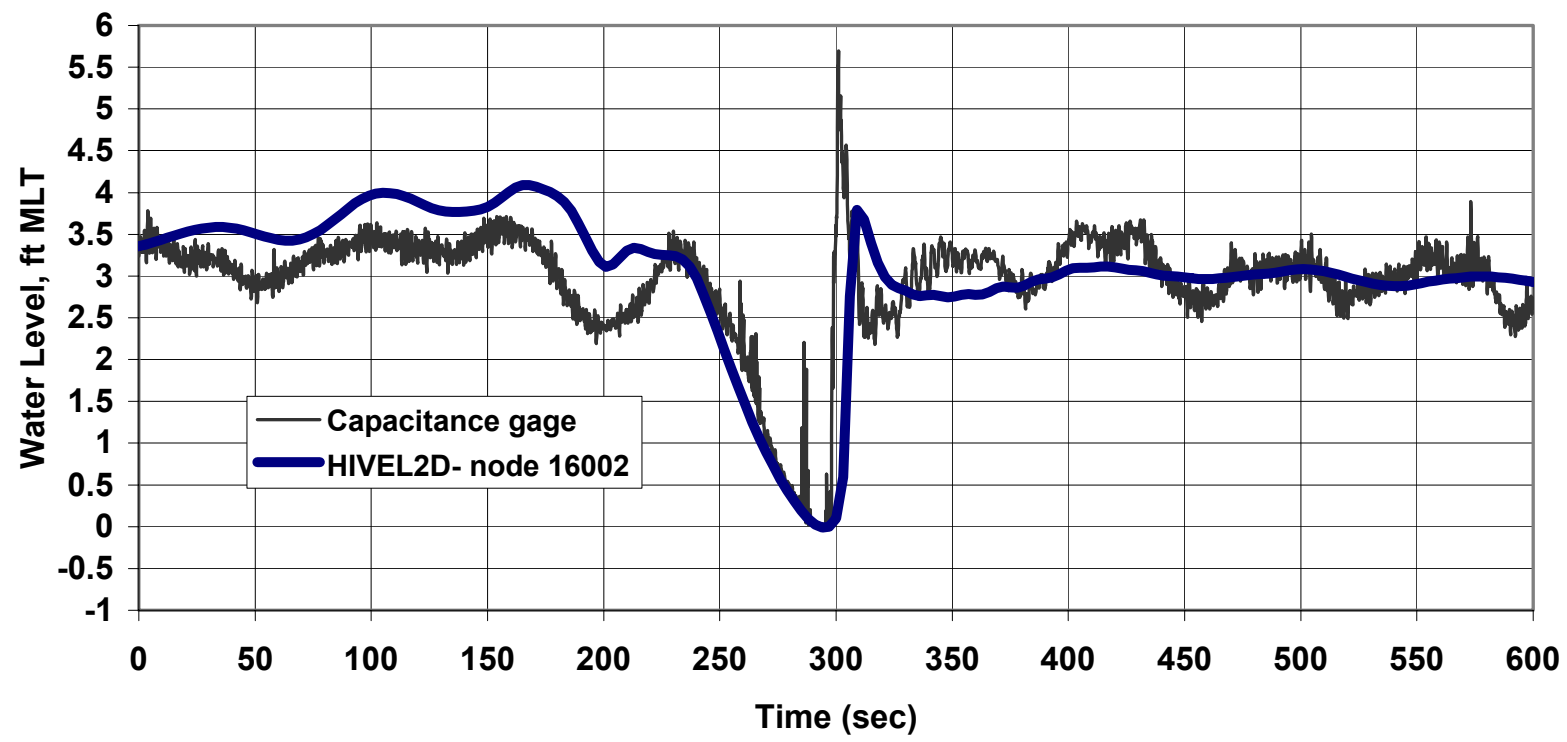

Figure 22. Observed and HIVEL2D water level for Pacific Sapphire at near-bank capacitance gage 10522, south site, existing channel 


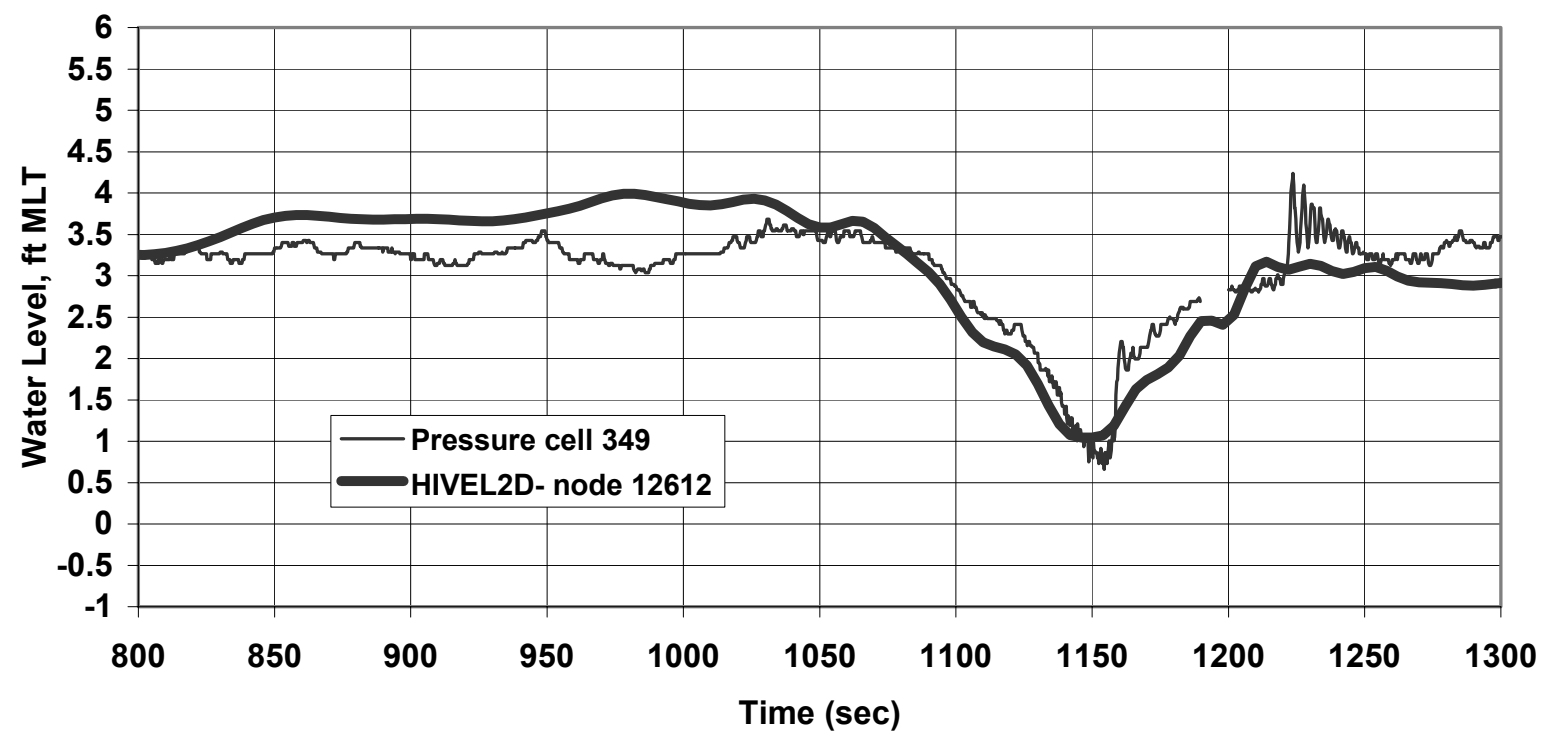

Figure 23. Observed and HIVEL2D water level for Pacific Sapphire at pressure cell 10349, north site, existing channel

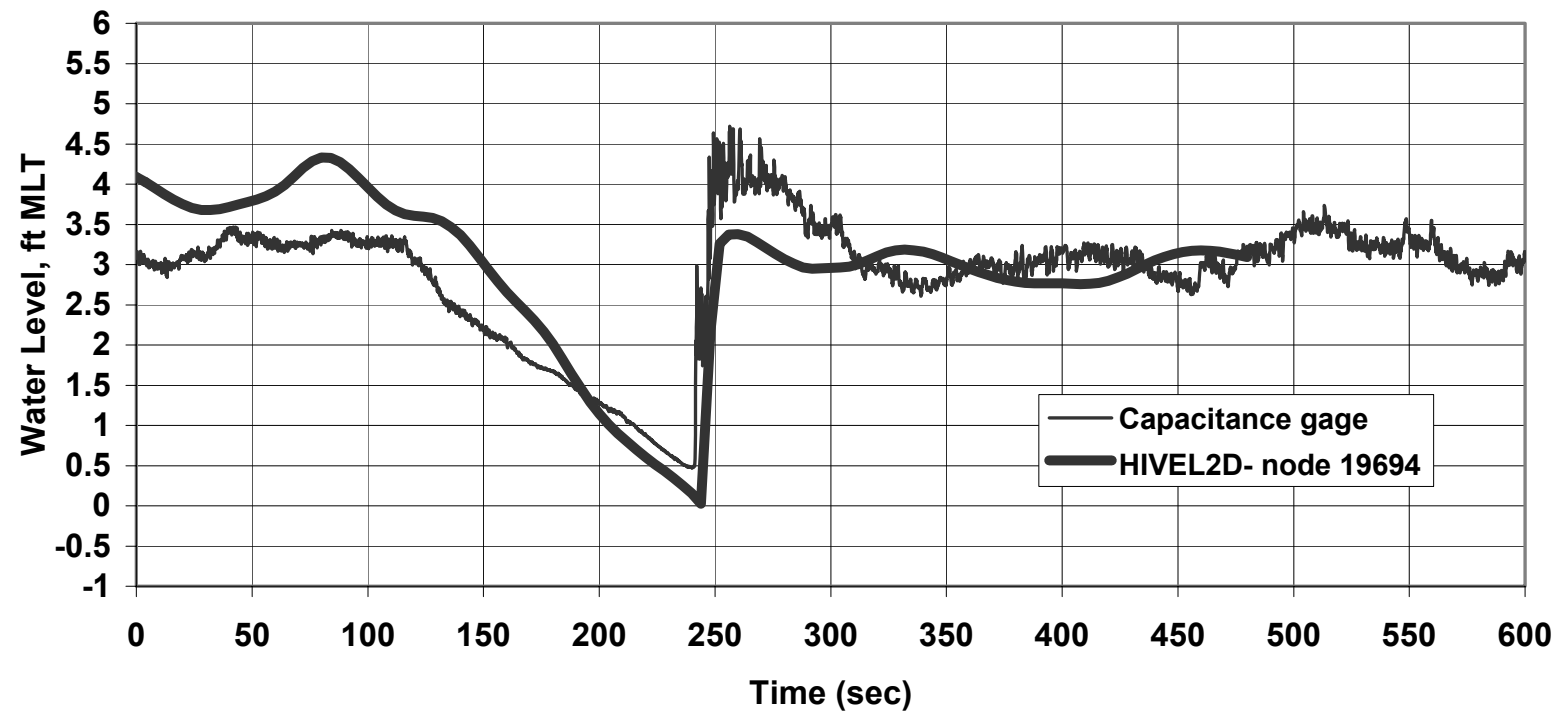

Figure 24. Observed and HIVEL2D water level for Pacific Sapphire at near-bank capacitance gage 10526, north site, existing channel 


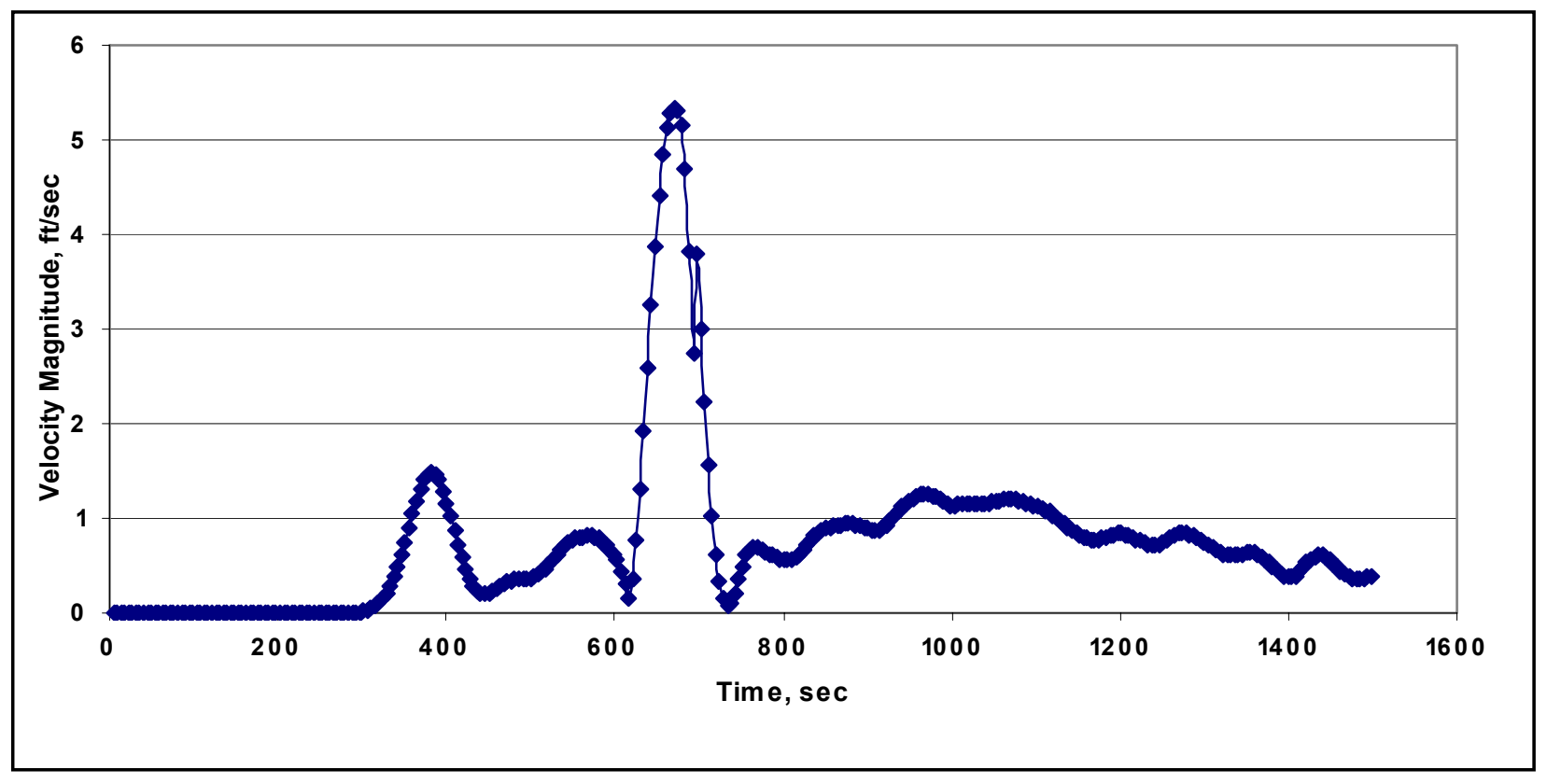

Figure 25. Computed velocity for Bornes at south site. Compare to measured velocity in Appendix Figure A11

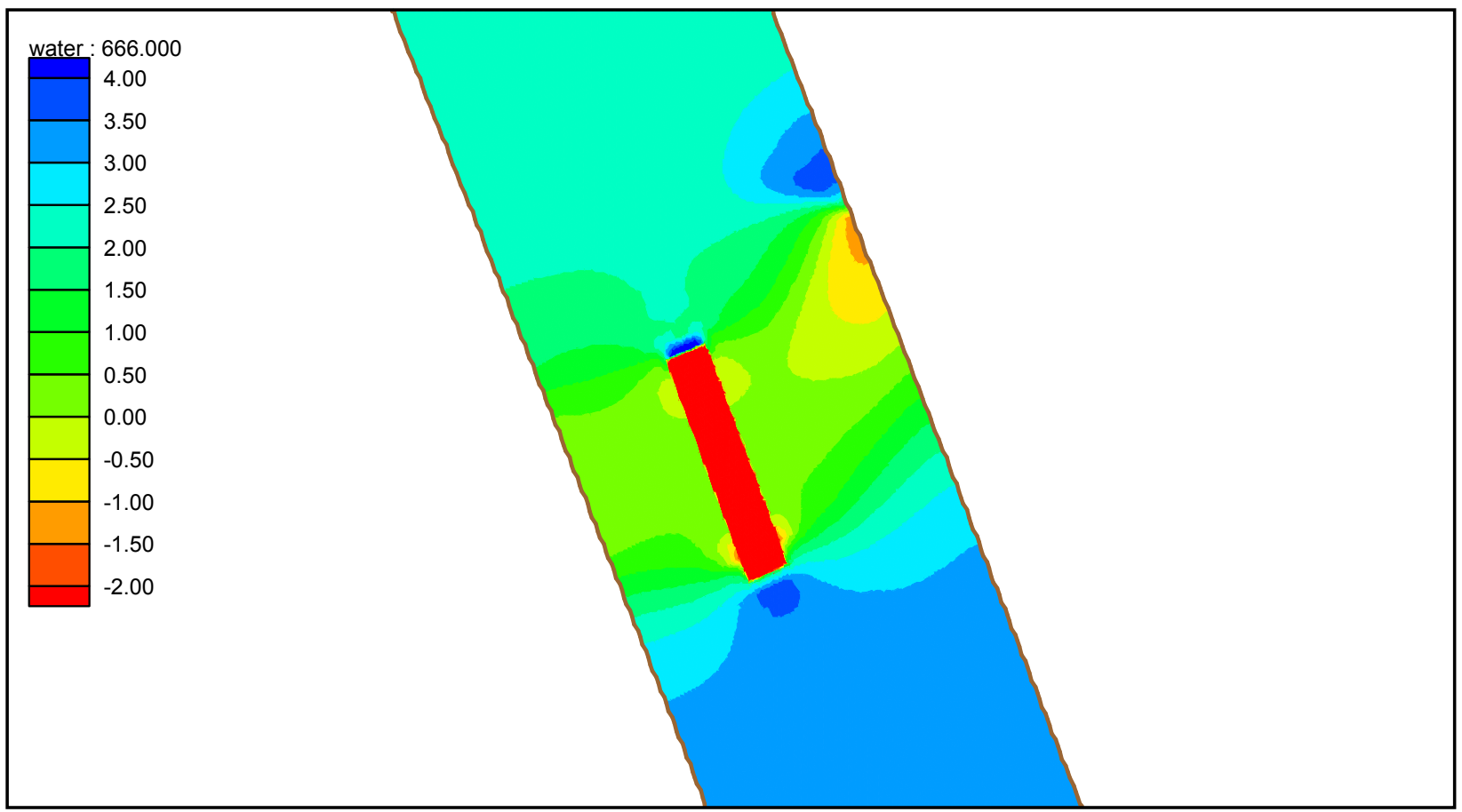

Figure 26. Water level, design ship, south site, existing channel, 10 knots, contours are ft mlt 


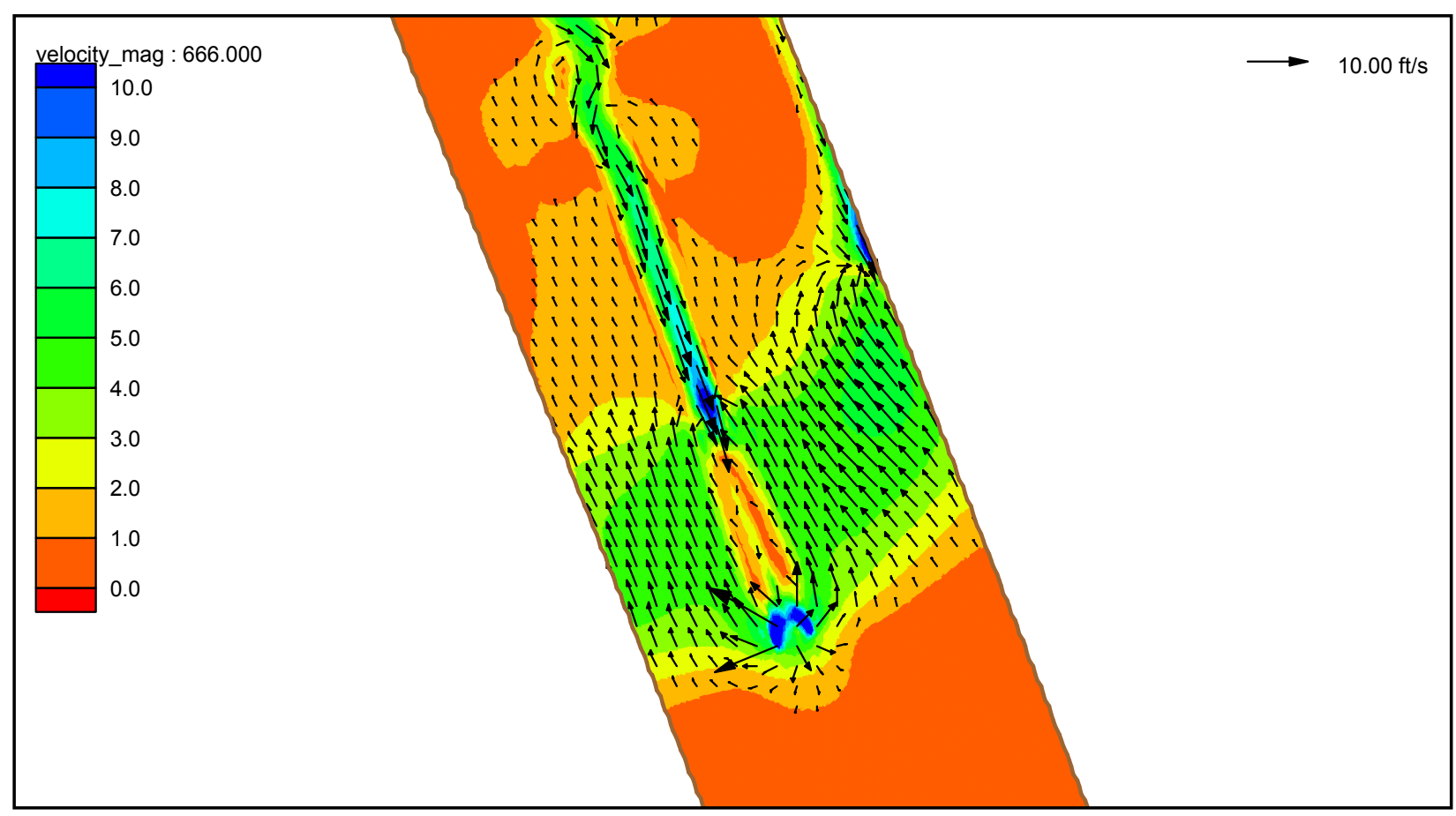

Figure 27. Velocity, design ship, south site, existing channel, 10 knots, contours are ft/sec

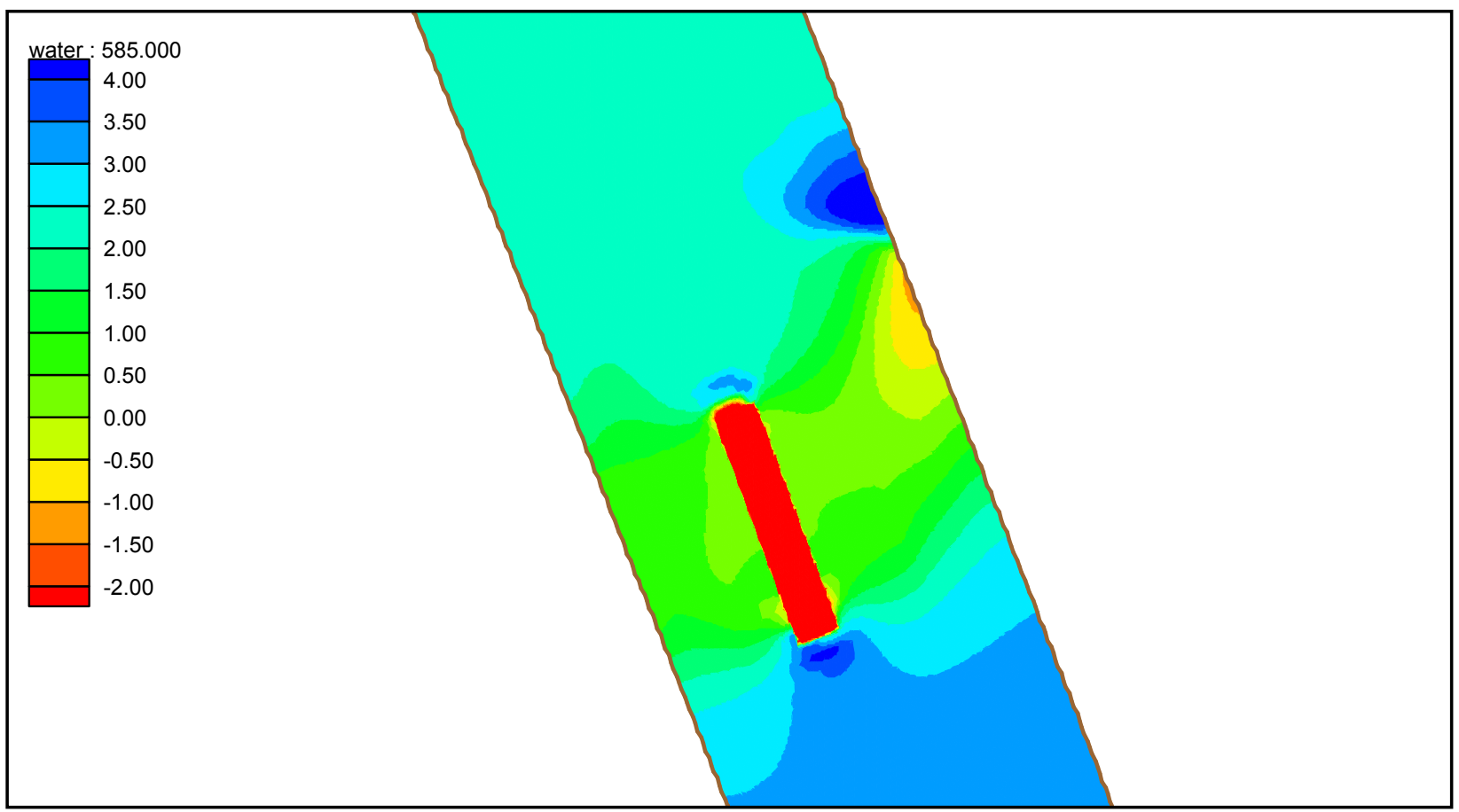

Figure 28. Water level, design ship, south site, proposed channel, 11.5 knots, contours are ft, mlt 


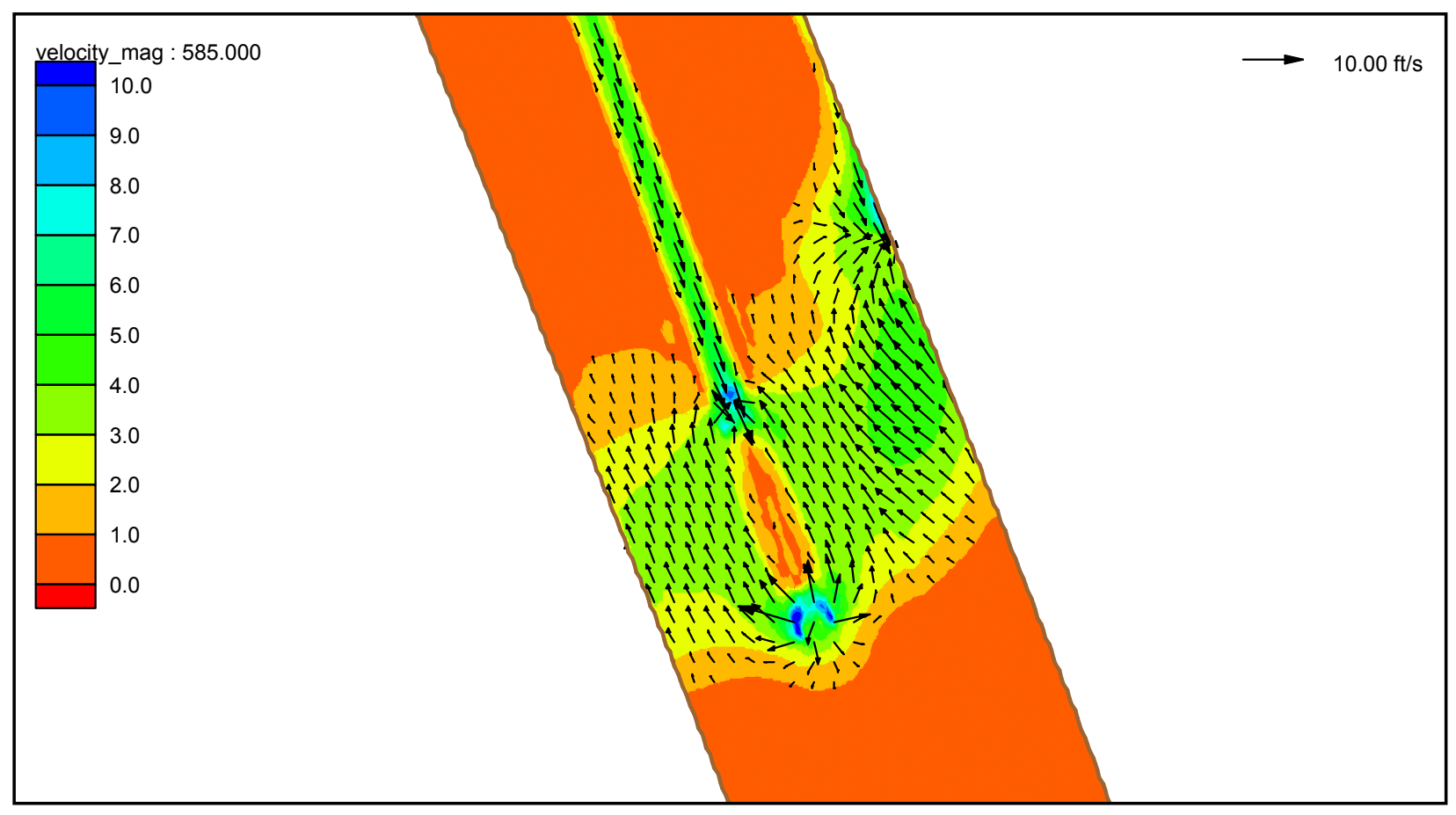

Figure 29. Velocity, design ship, south site, proposed channel, 11.5 knots, contours are ft/sec

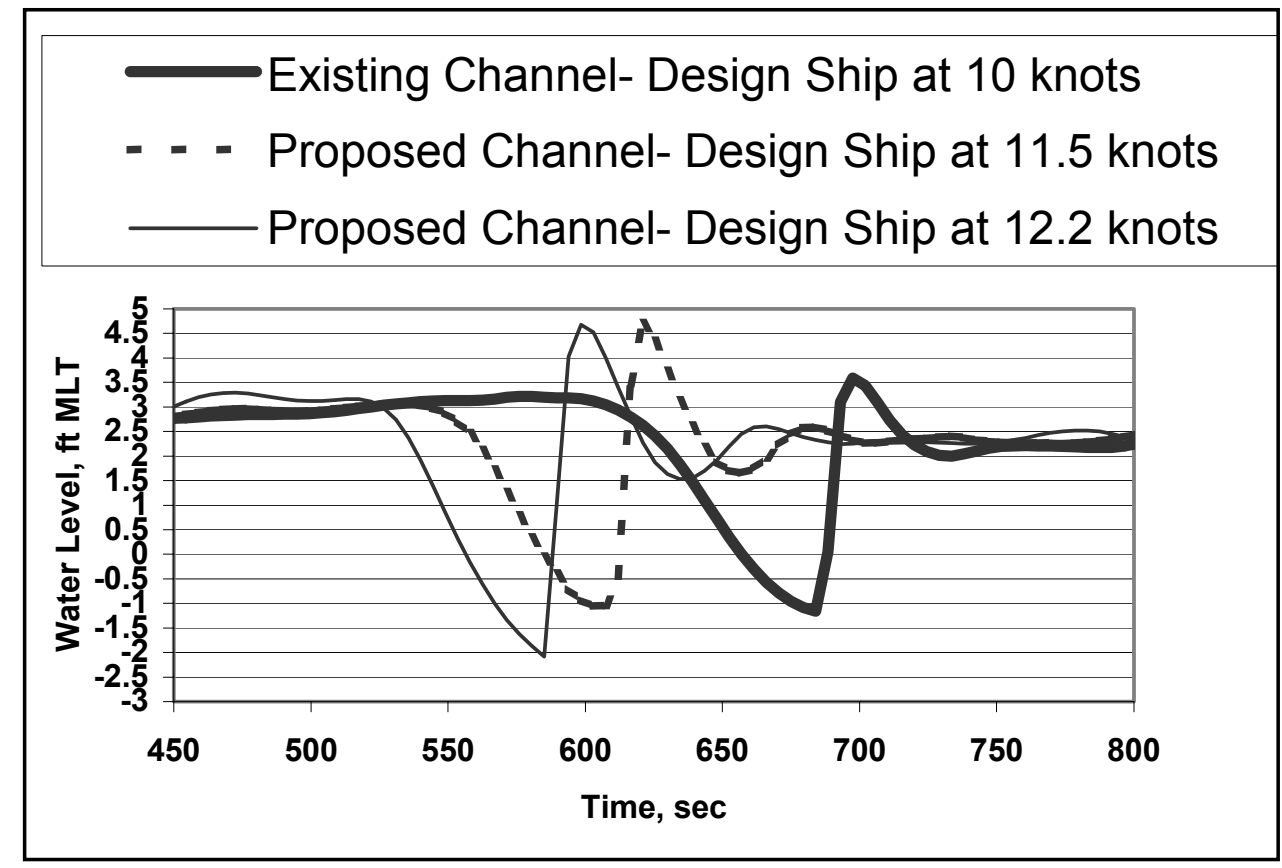

Figure 30. Computed water level at shoreline, south site, design ship, existing and proposed channels, node 16002 


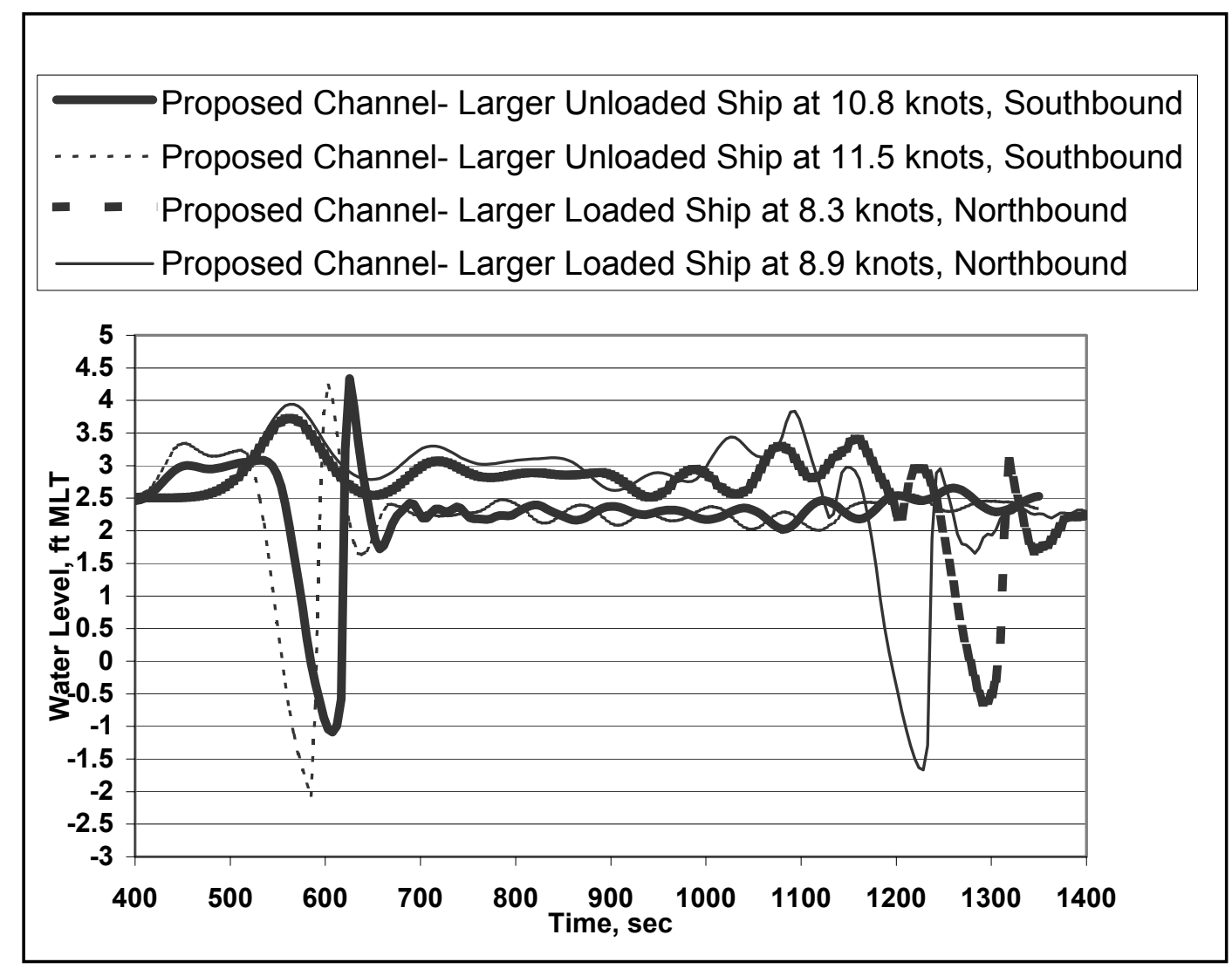

Figure 31. Computed water level at shoreline, south site, loaded and unloaded larger ship, proposed channel, node 16002

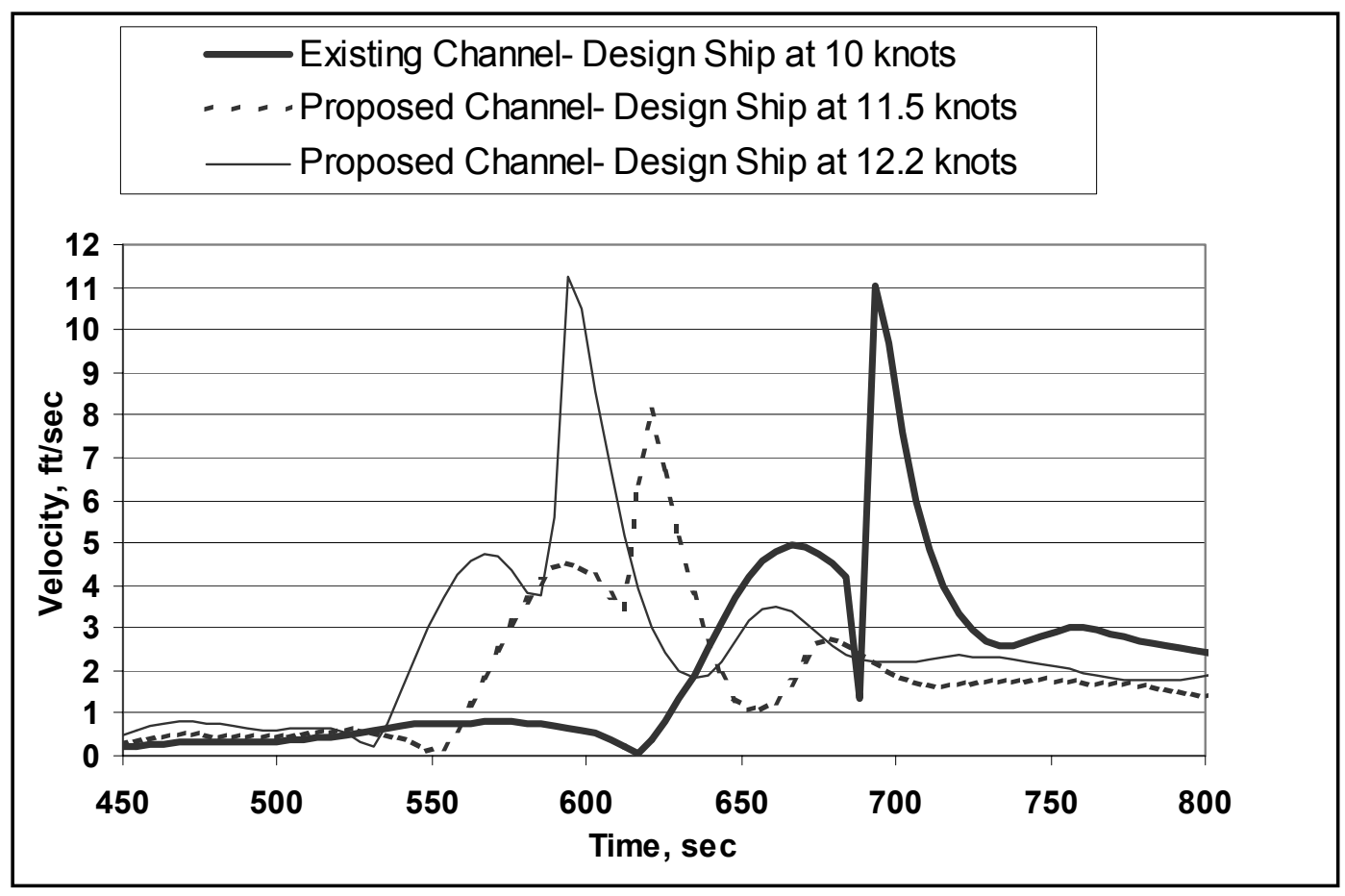

Figure 32. Computed velocity at shoreline, south site, design ship, existing and proposed channels, node 16002 


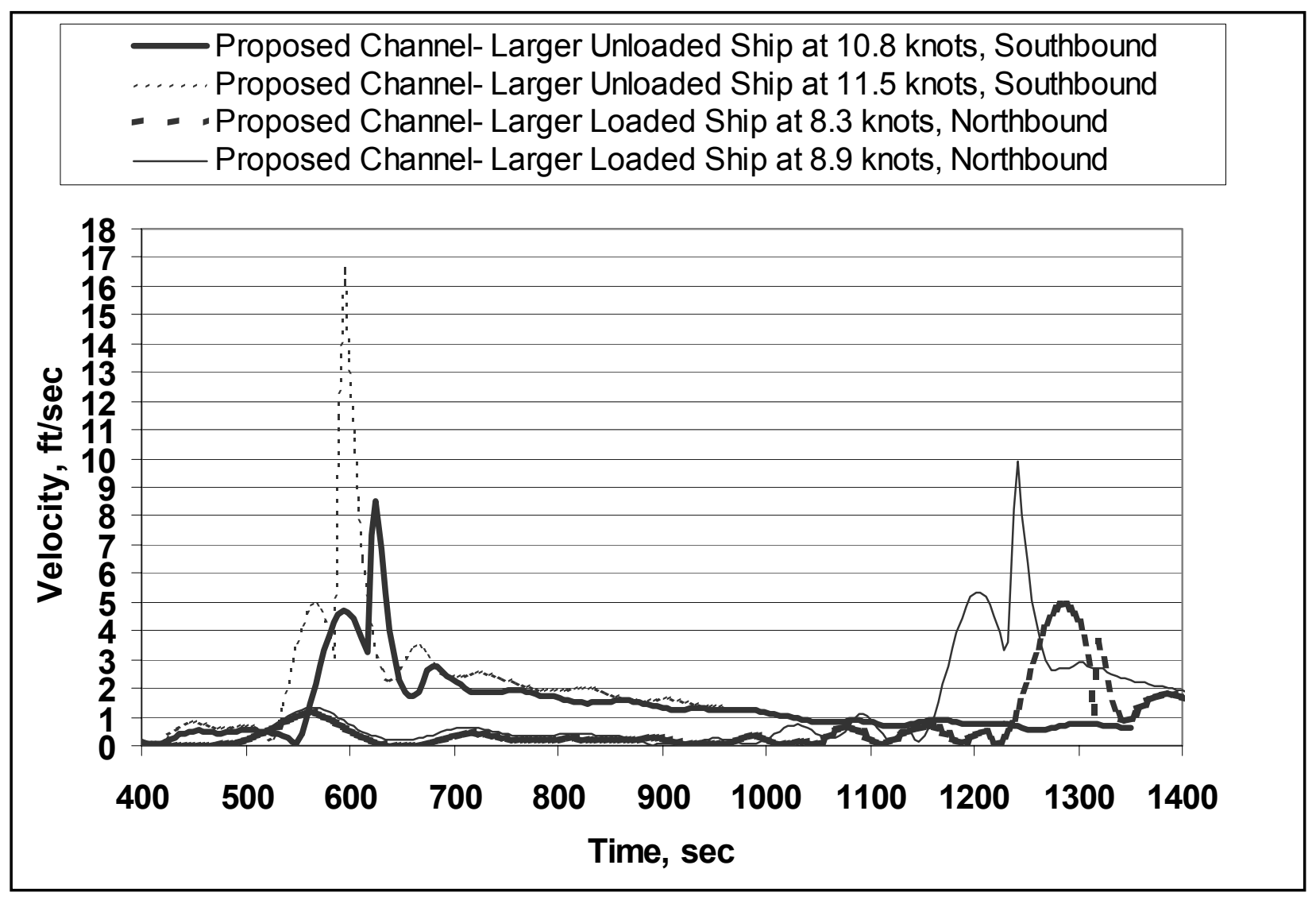

Figure 33. Computed velocity at shoreline, south site, loaded and unloaded larger ship, proposed channel, node 16002

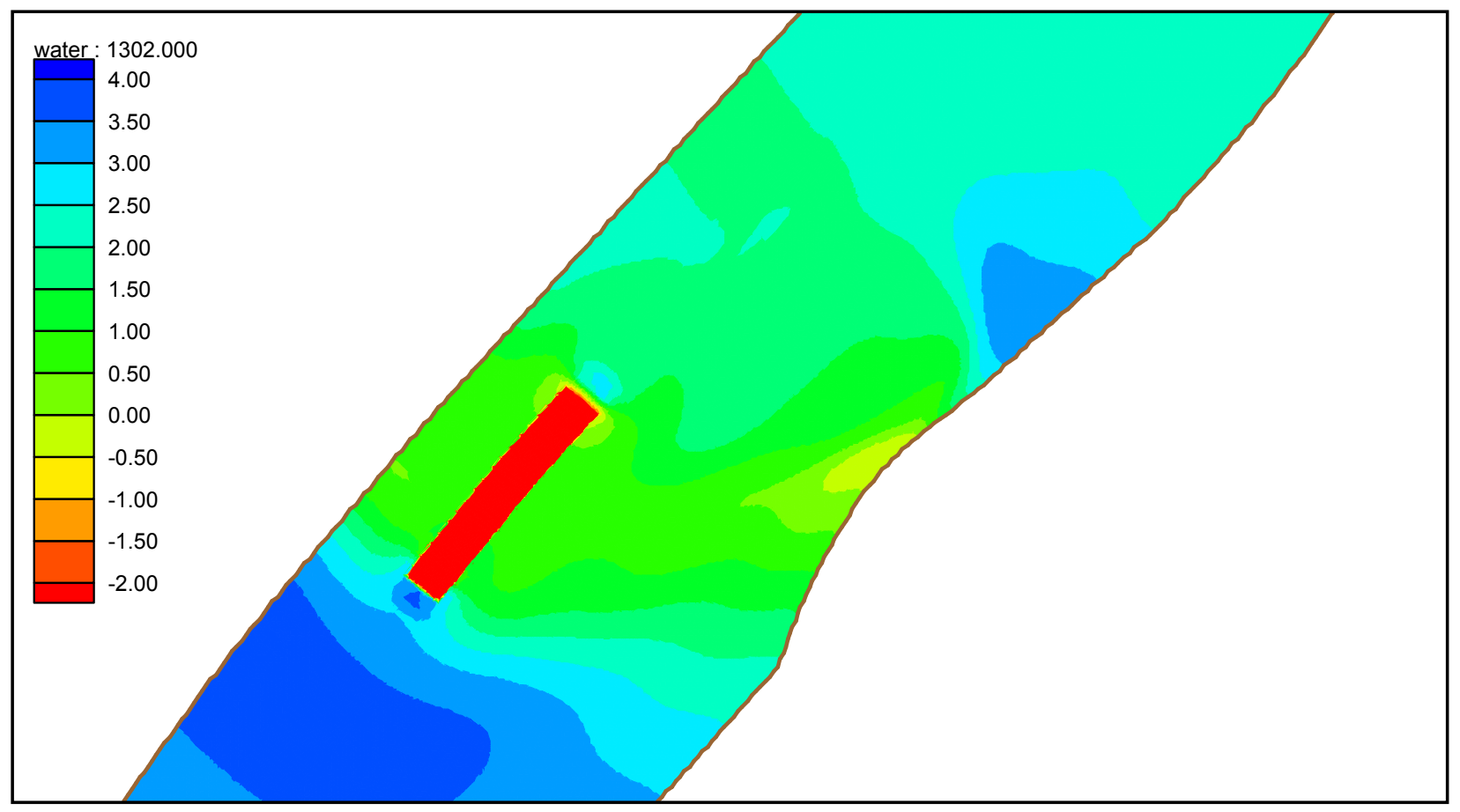

Figure 34. Water level, design ship, north site, existing channel, 9 knots, contours in $\mathrm{ft}$, mlt, ship travels from upper right to lower left 


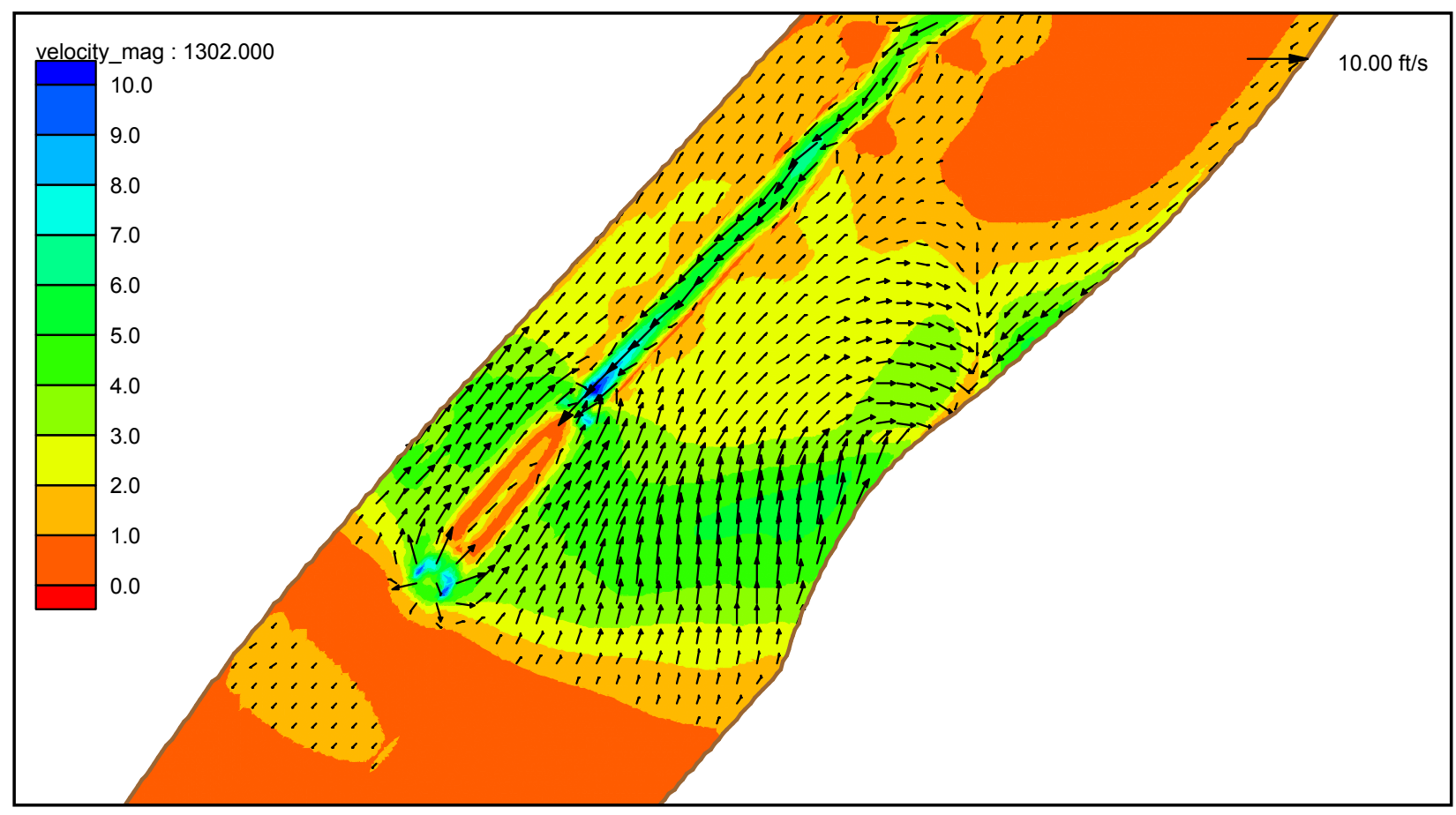

Figure 35. Velocity, design ship, north site, existing channel, 9 knots, contours in ft/sec, ship travels from upper right to lower left

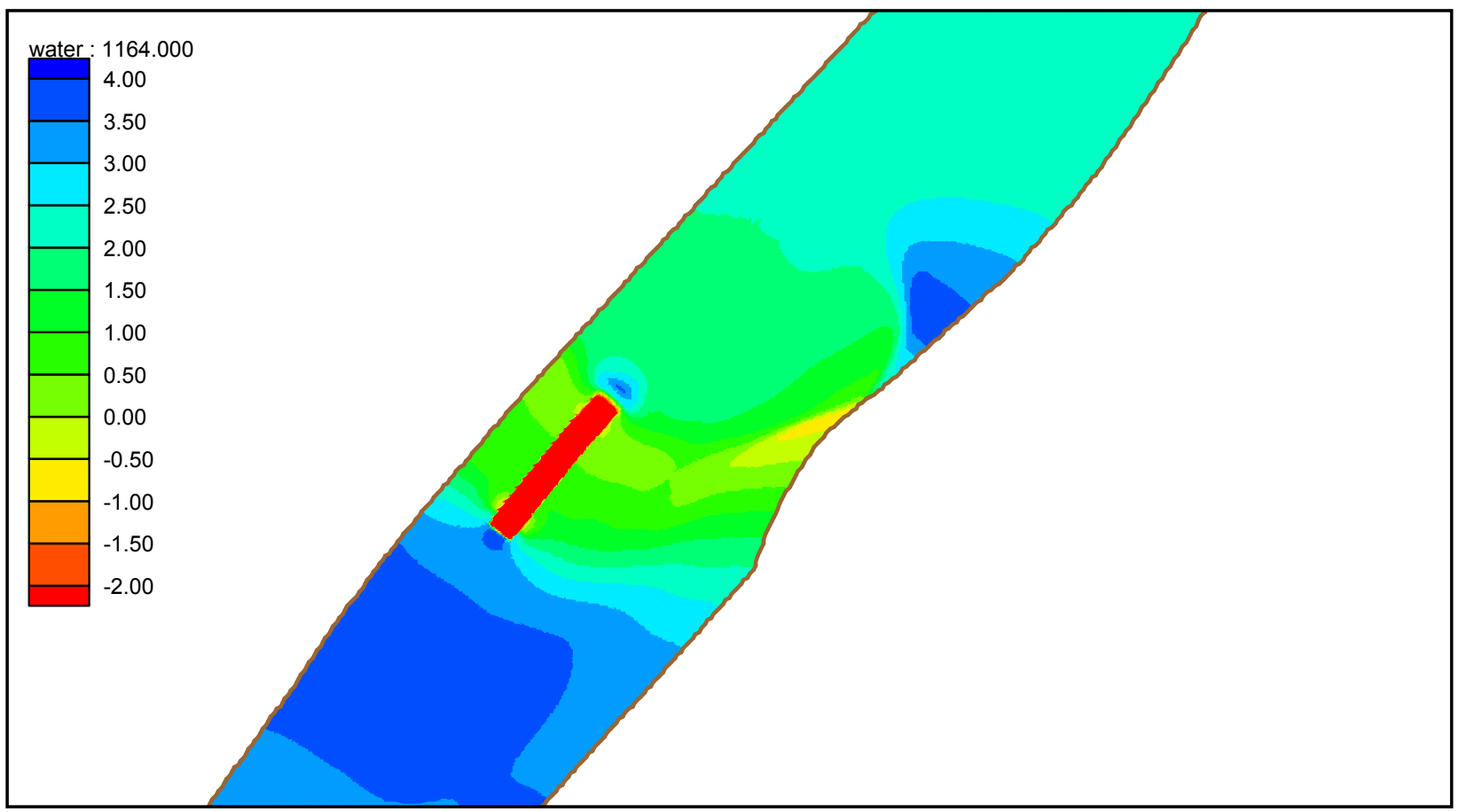

Figure 36. Water level, design ship, north site, proposed channel, $10.2 \mathrm{knots}$, contours are in ft, mlt, ship travels from upper right to lower left 


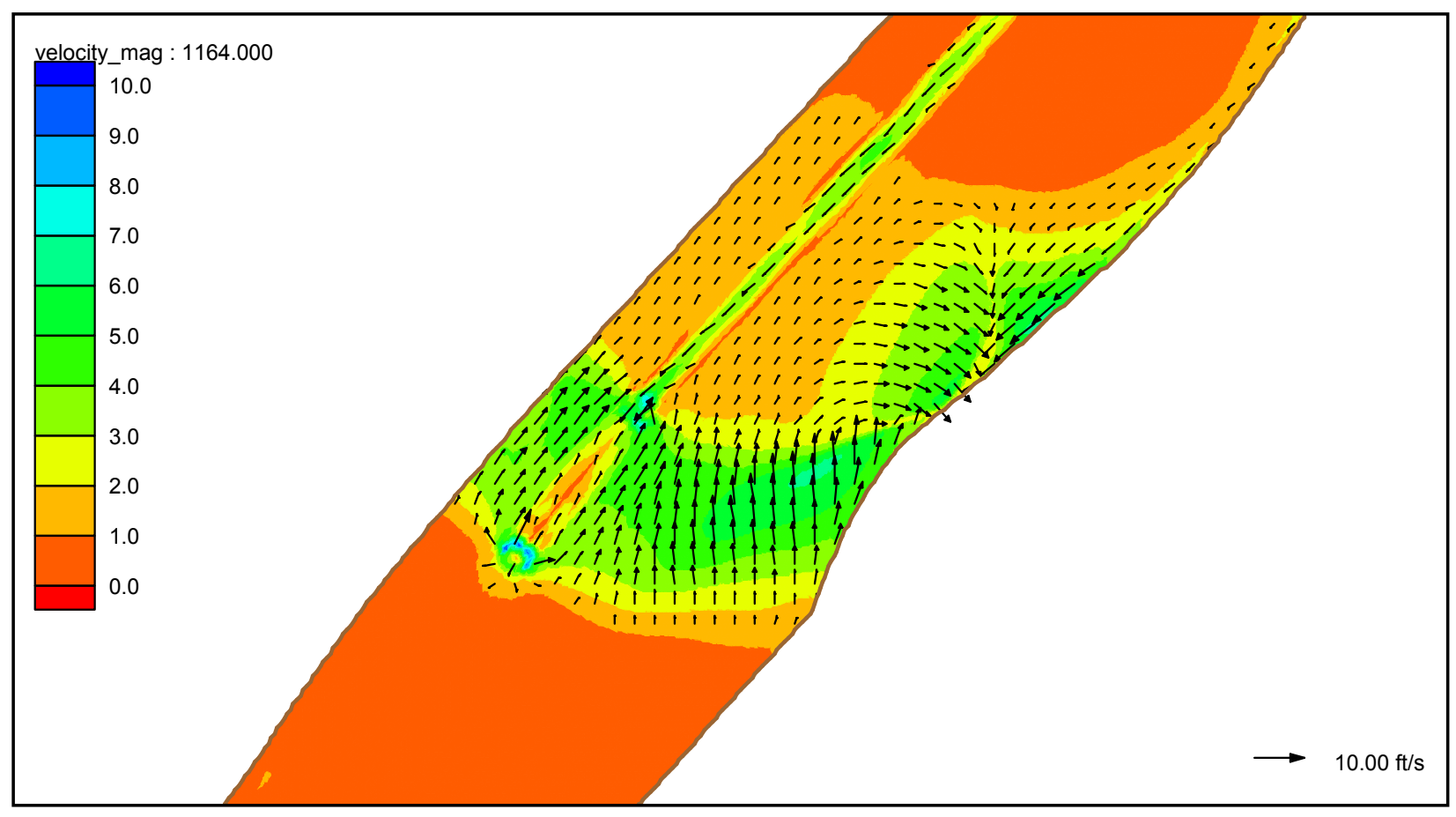

Figure 37. Velocity, design ship, north site, proposed channel, 10.2 knots, velocity contours in ft/sec

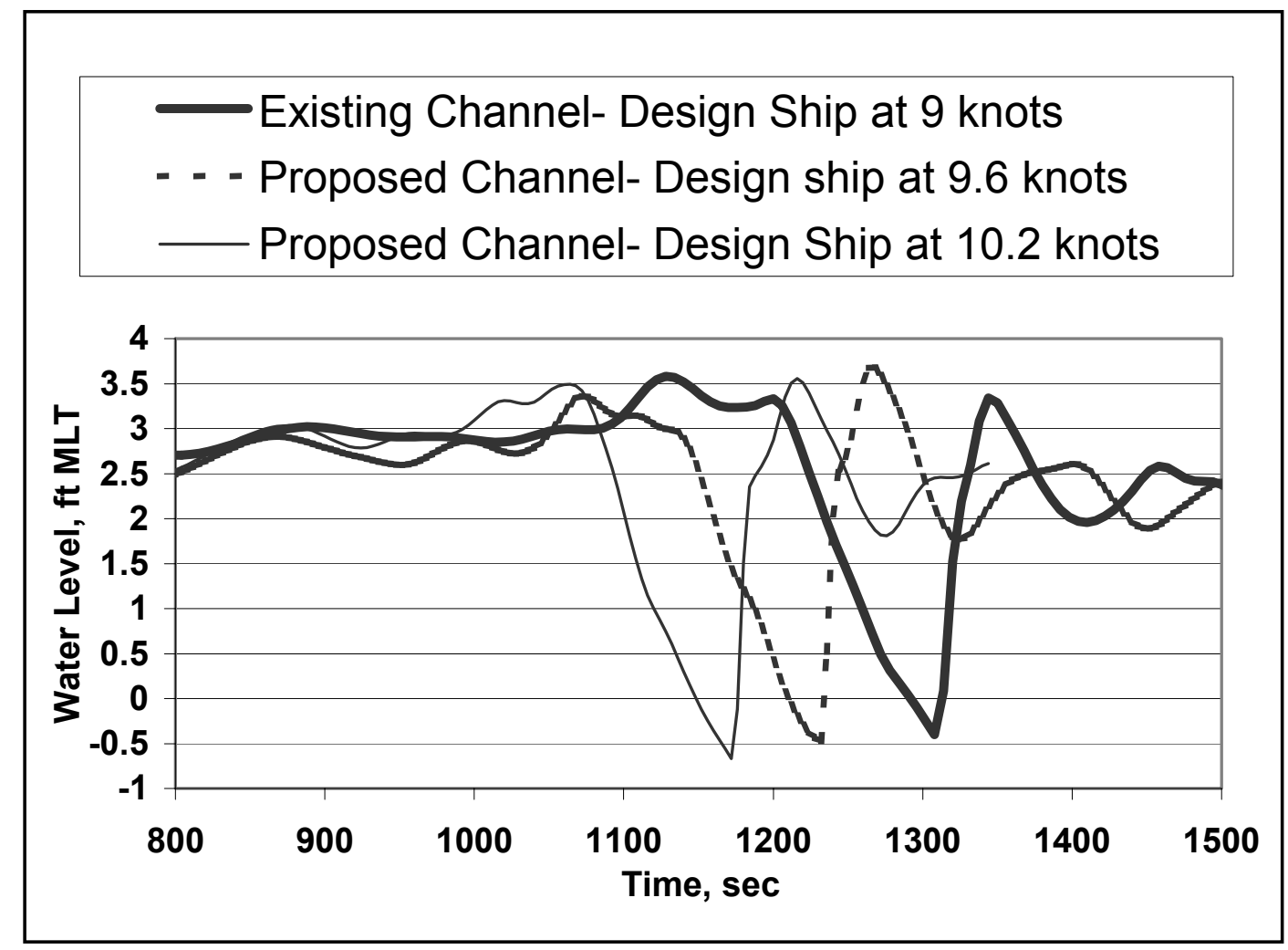

Figure 38. Computed water level at shoreline, north site, design ship, existing and proposed channels, node 16952 


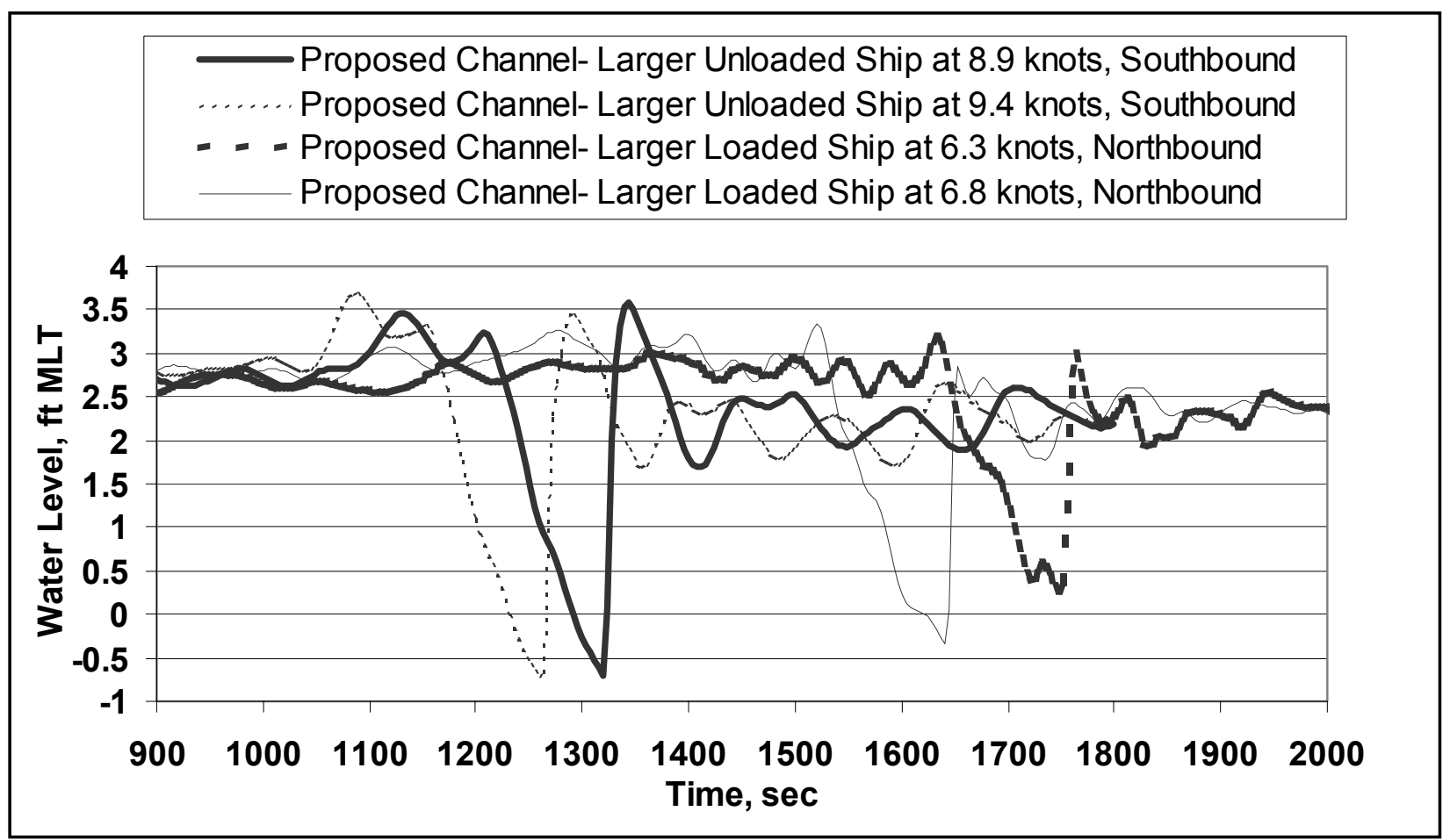

Figure 39. Computed water level at shoreline, north site, loaded and unloaded larger ship, proposed channel, node 16952

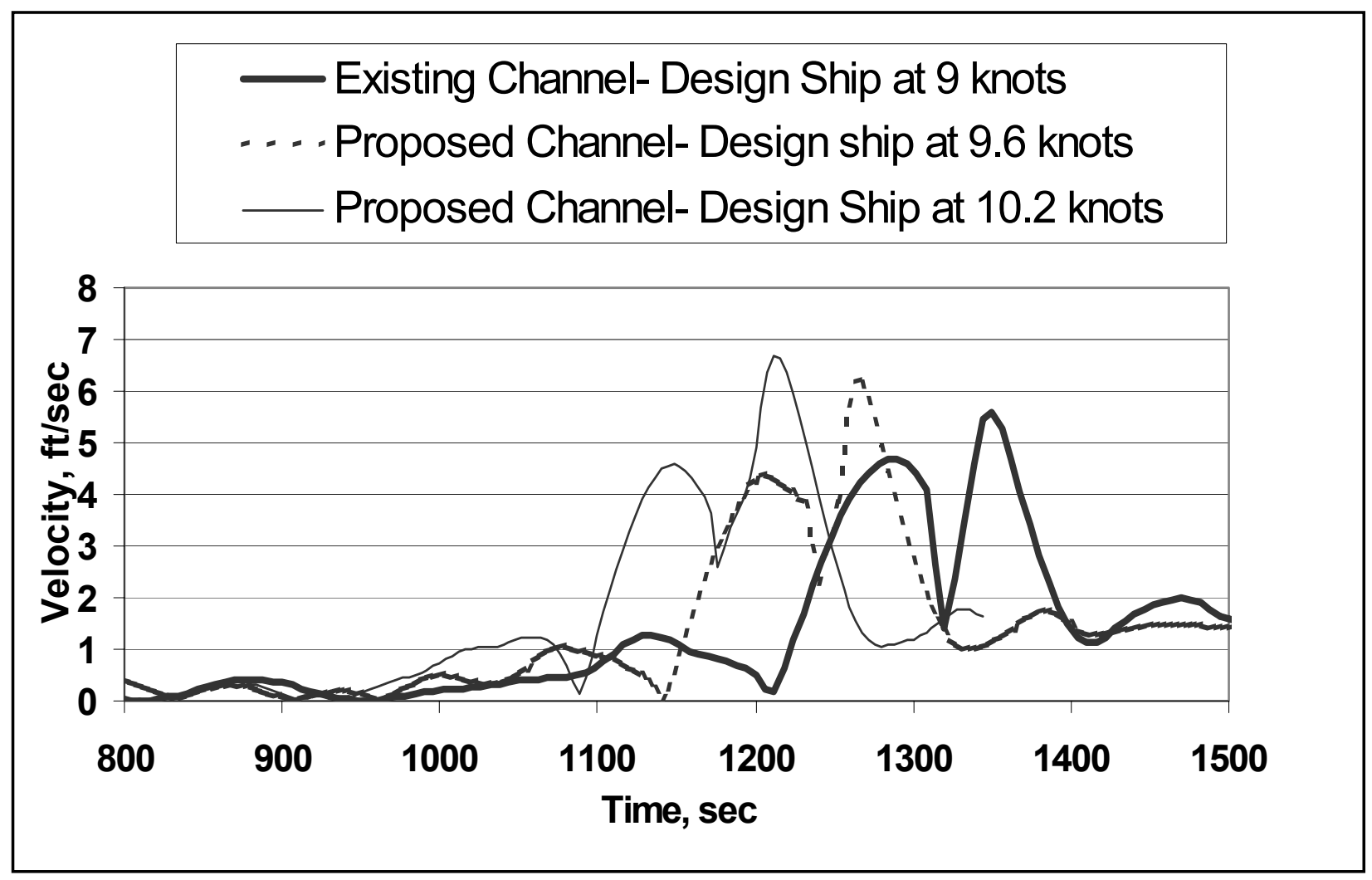

Figure 40. Computed velocity at shoreline, north site, design ship, existing and proposed channels, node 16952 


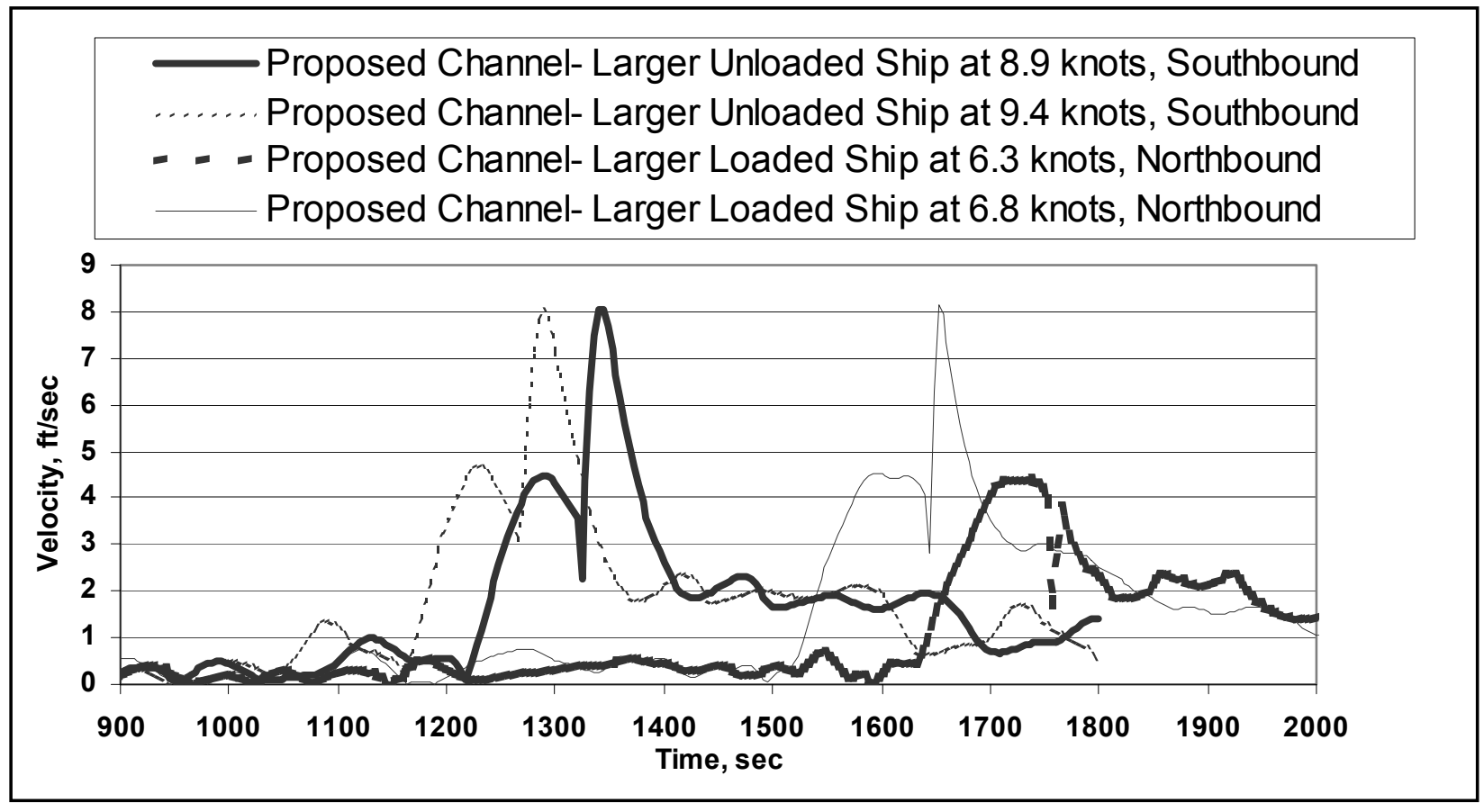

Figure 41. Computed velocity at shoreline, north site, loaded and unloaded larger ship, proposed channel, node 16952

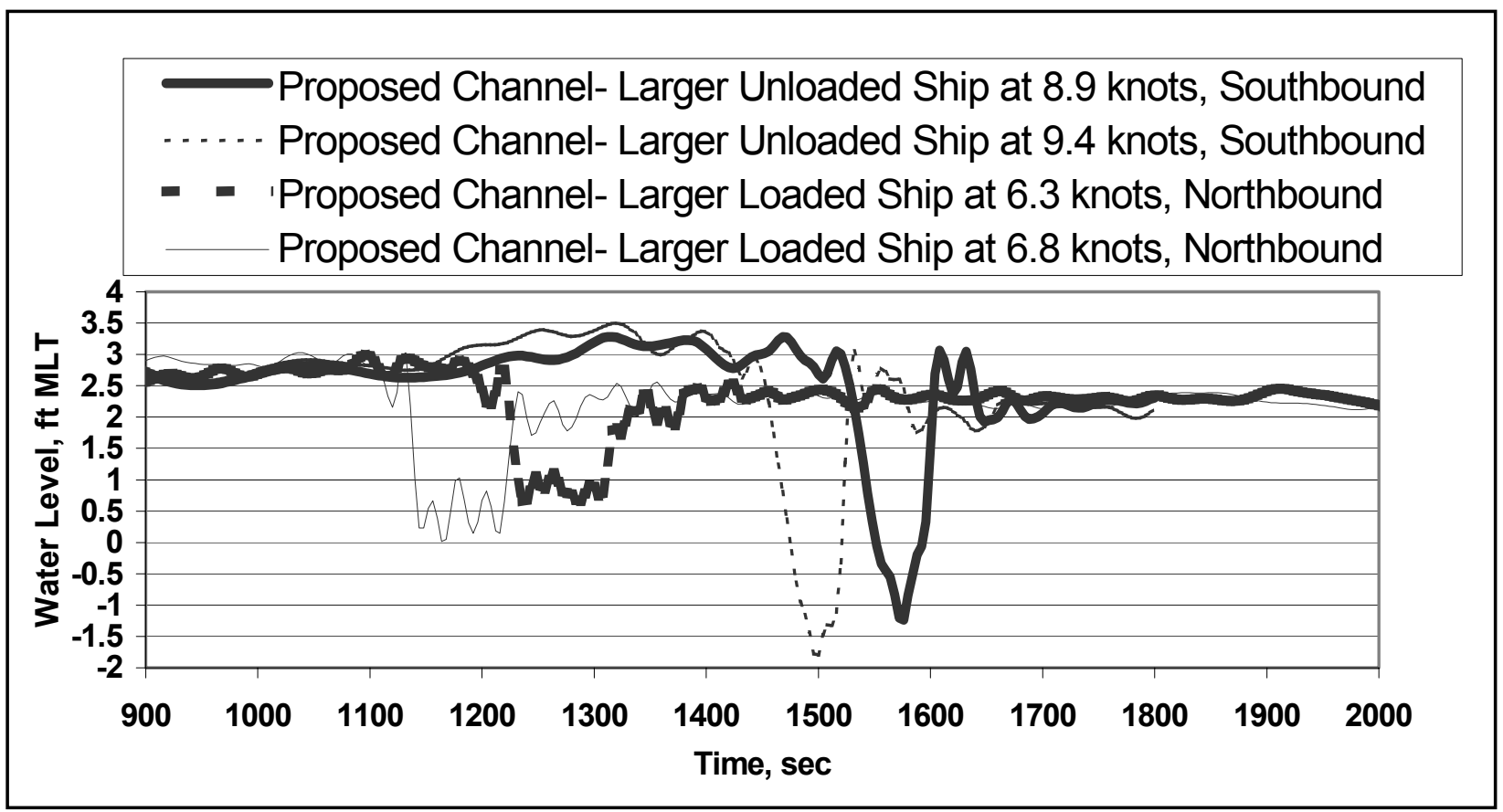

Figure 42. Computed water level at shoreline, north site, loaded and unloaded larger ship, proposed channel, node 9753 


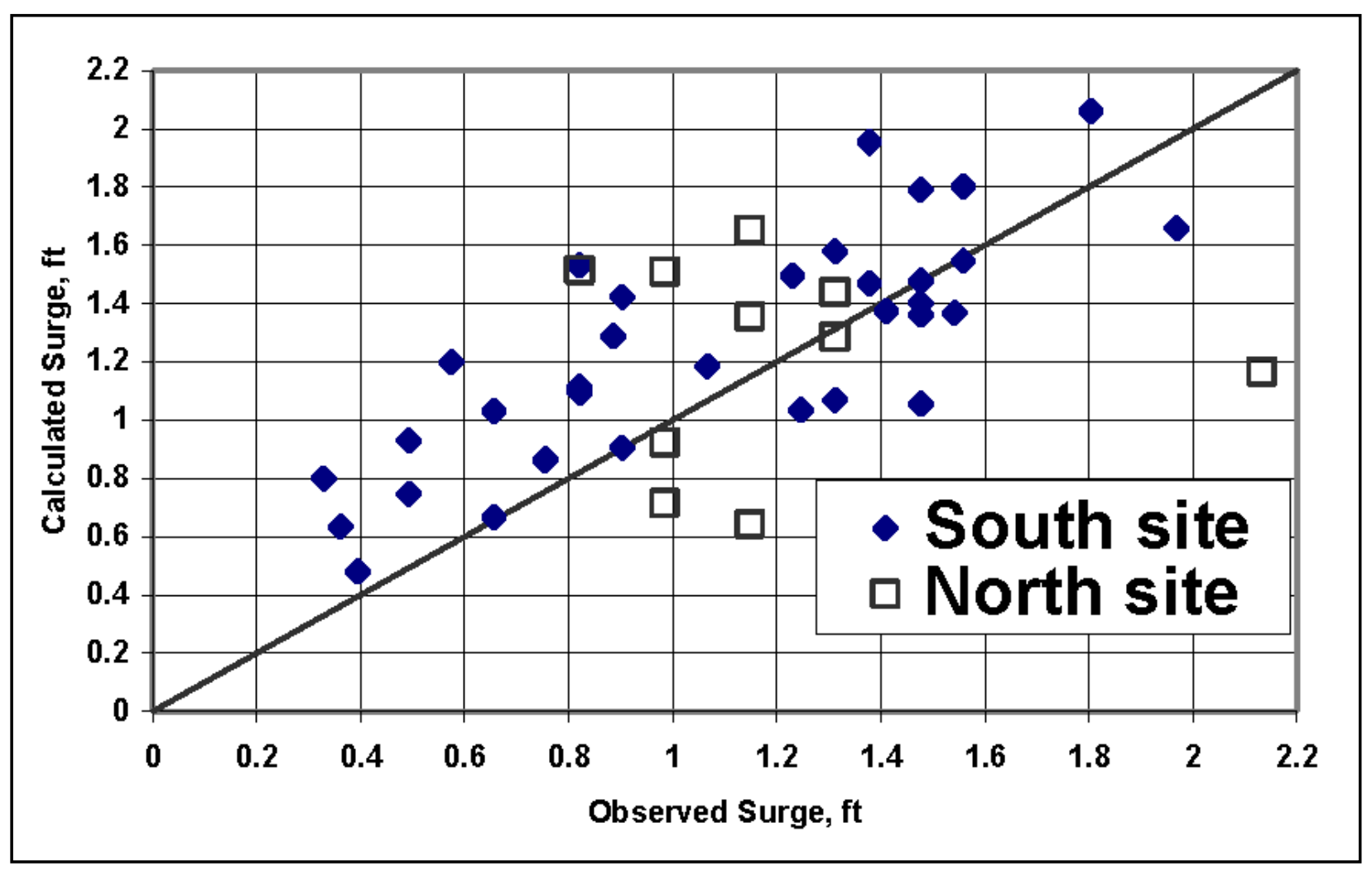

Figure 43. Scatterplot of observed versus calculated surge using Equation 5

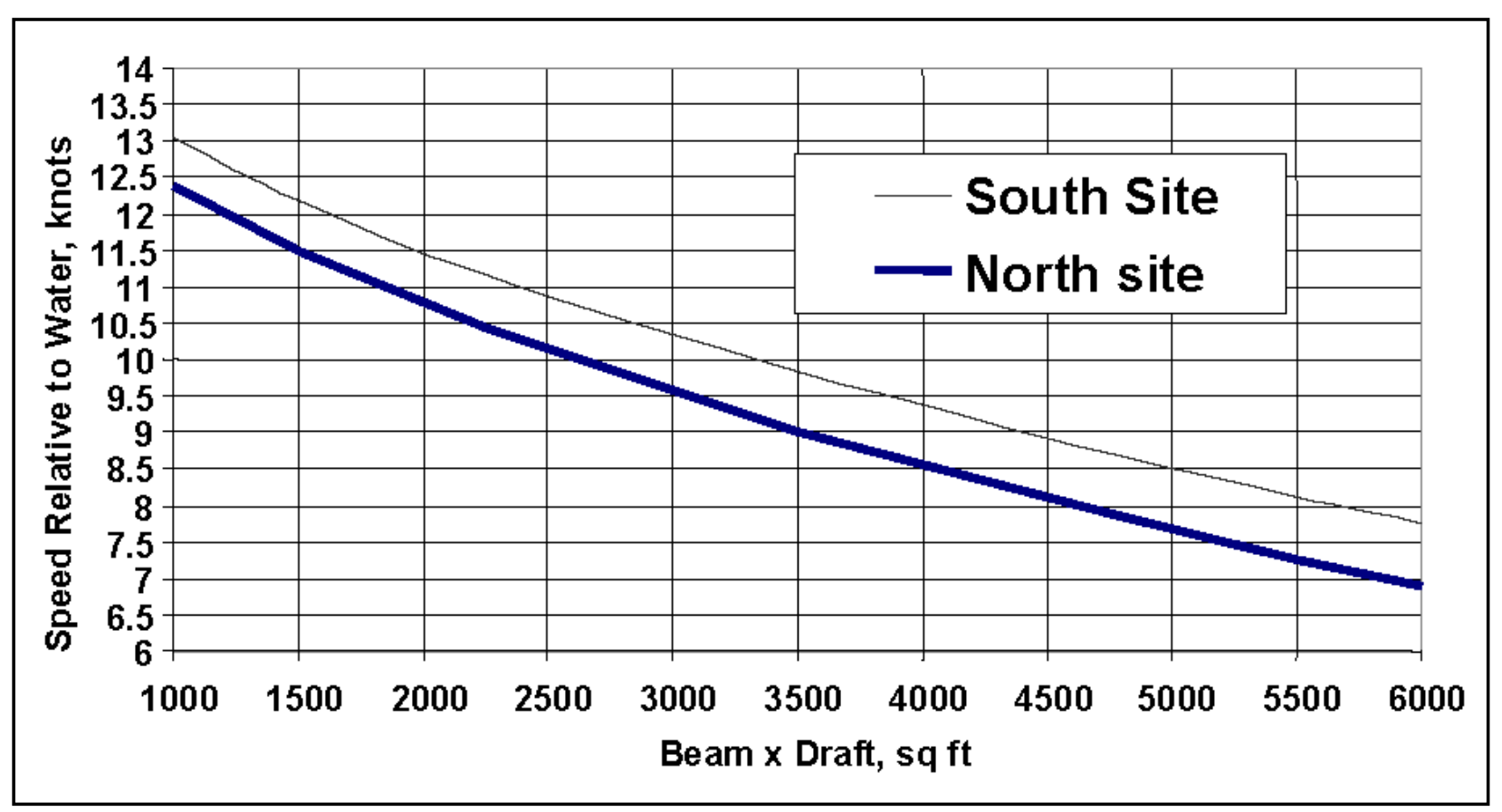

Figure 44. Speeds used in speed effects study equal to 80 percent of limit speed 


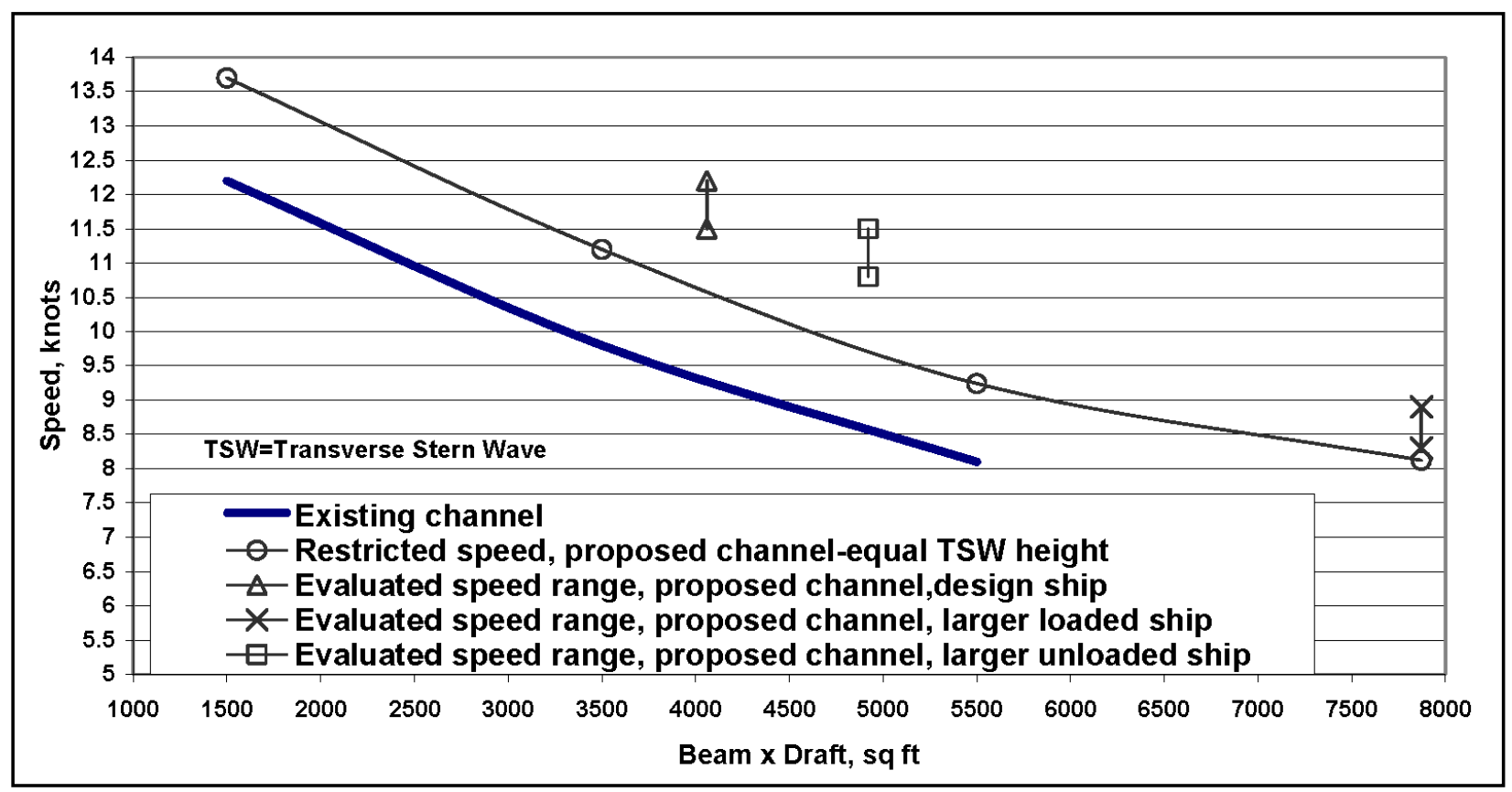

Figure 45. Speeds in proposed channel, equal TSW, south site, Port Arthur Canal

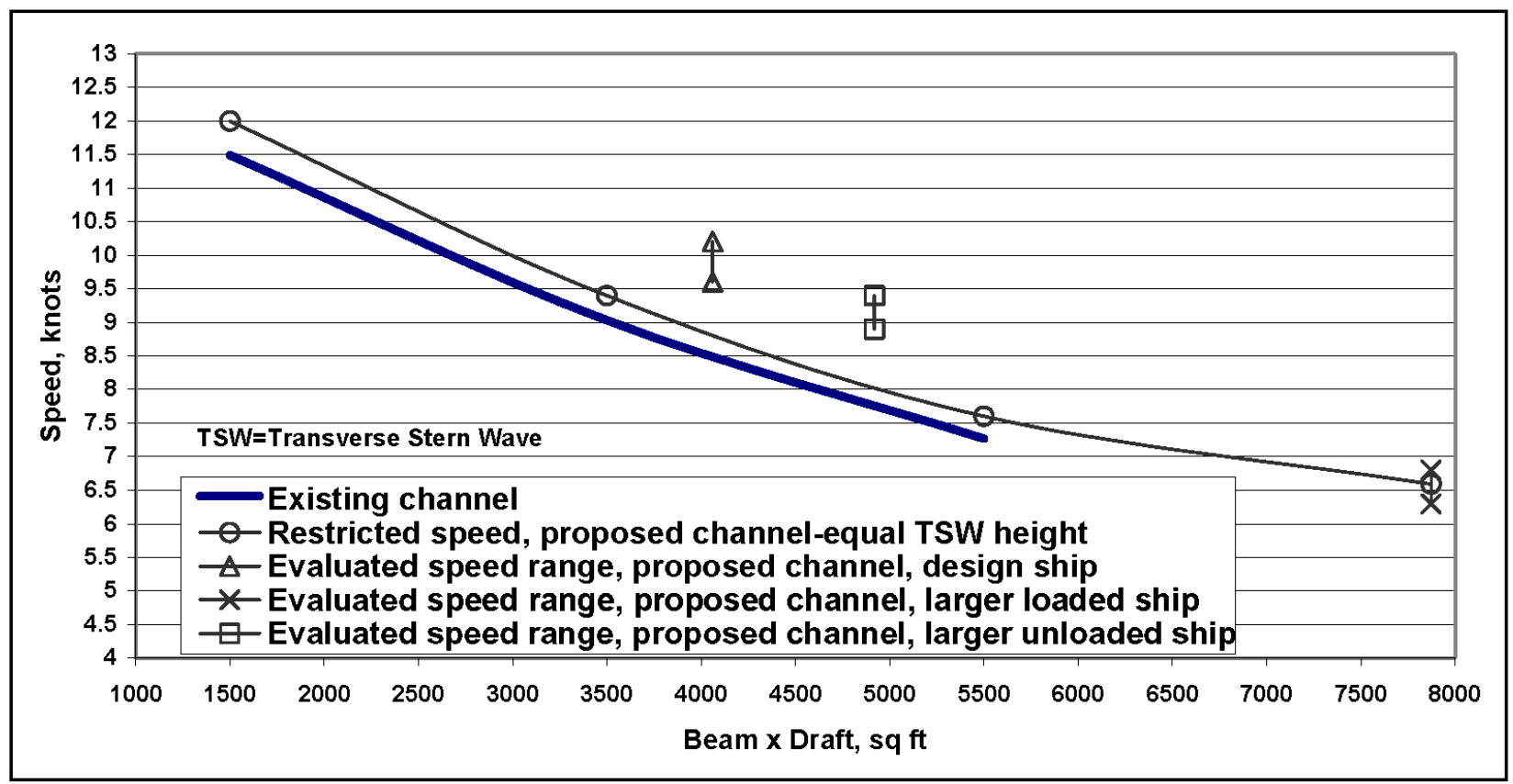

Figure 46. Speeds in proposed channel, equal TSW, north site, Sabine-Neches Canal 


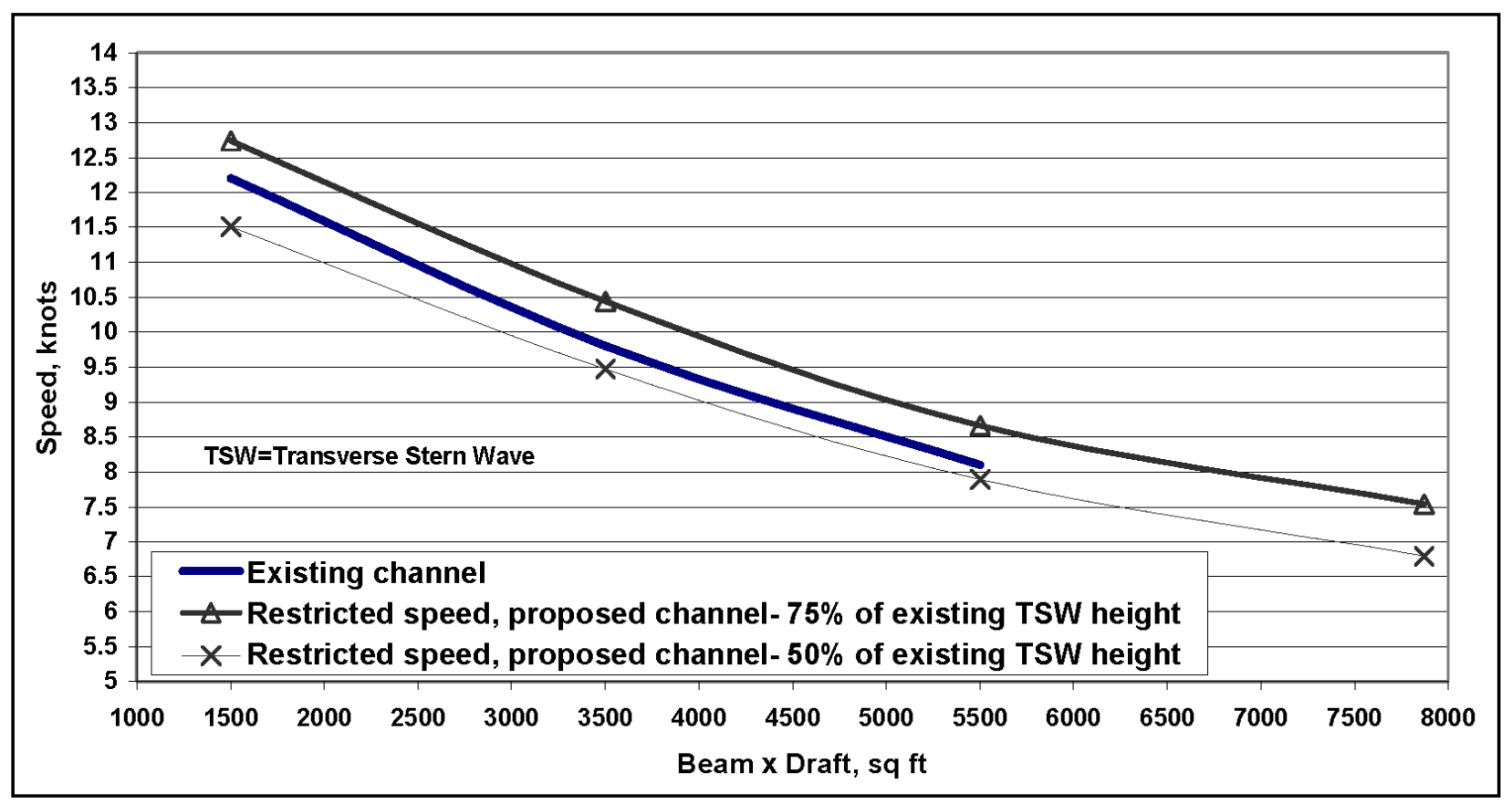

Figure 47. Speeds in proposed channel, less TSW, south site, Port Arthur Canal

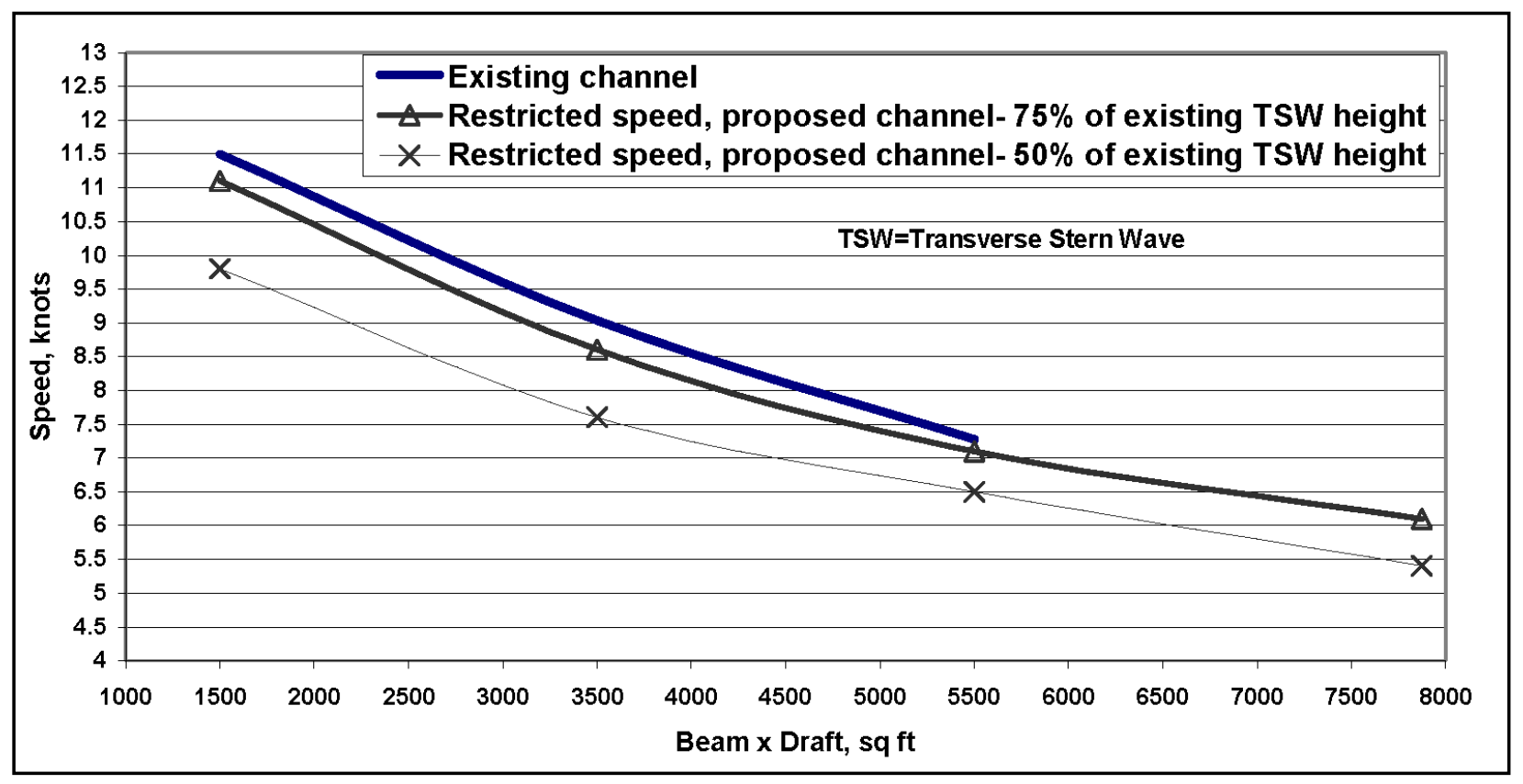

Figure 48. Speeds in proposed channel, less TSW, north site, Sabine-Neches Canal 


\begin{tabular}{|c|c|c|c|c|}
\hline \multicolumn{5}{|c|}{$\begin{array}{l}\text { Table } 1 \\
\text { Pressure Cell Descriptions and Locations }\end{array}$} \\
\hline $\begin{array}{l}\text { Cell } \\
\text { Number }\end{array}$ & Location & Time In/Out Water & $\begin{array}{l}\text { Depth } \\
\text { m (ft) } \\
\text { below } \\
\text { mlt }\end{array}$ & $\begin{array}{l}\text { State Plane, NAD83, } \\
\text { Texas South Central- } \\
\mathbf{4 2 0 4}\end{array}$ \\
\hline \multirow[t]{2}{*}{$\overline{1200346 \mathrm{~B}}$} & \multirow[t]{10}{*}{ South } & 04/30/02-0705 CST-in & \multirow[t]{4}{*}{$0.5(1.7)$} & \multirow{4}{*}{$\begin{array}{l}3571268,13868525- \\
\text { about } 660 \mathrm{ft} \text { from channel } \\
\text { center line }\end{array}$} \\
\hline & & 05/01/02-1420 CST-out & & \\
\hline \multirow[t]{2}{*}{ 1210346B } & & 05/01/02-1500 CST-in & & \\
\hline & & 05/03/02-0750 CST-out & & \\
\hline \multirow[t]{2}{*}{ 1200347B } & & 04/30/02-0750 CST-in & \multirow[t]{6}{*}{$1.1(3.6)$} & \multirow{6}{*}{$\begin{array}{l}3570555,13870352- \\
\text { about } 620 \mathrm{ft} \text { from channel } \\
\text { center line }\end{array}$} \\
\hline & & 05/02/02-1500 CST-out & & \\
\hline \multirow[t]{2}{*}{ 1210347B } & & 05/01/02-1520 CST-in & & \\
\hline & & 05/03/02-0740 CST-out & & \\
\hline \multirow[t]{2}{*}{$1230347 \mathrm{~B}$} & & 05/03/02-0830 CST-in & & \\
\hline & & 05/04/02-0830 CST-out & & \\
\hline \multirow{2}{*}{ 1200349B } & \multirow{12}{*}{ North } & 04/30/02-1035 CST-in & \multirow[t]{6}{*}{$1.2(3.8)$} & \multirow{6}{*}{$\begin{array}{l}3581227,13906697- \\
\text { about } 740 \mathrm{ft} \text { from channel } \\
\text { center line }\end{array}$} \\
\hline & & 05/01/02-1635 CST-out & & \\
\hline \multirow[t]{2}{*}{ 1210349B } & & 05/01/02-1705 CST-in & & \\
\hline & & 05/03/02-1320 CST-out & & \\
\hline \multirow[t]{2}{*}{ 1230349B } & & 05/03/02-1430 CST-in & & \\
\hline & & 05/04/02-0745 CST-out & & \\
\hline \multirow[t]{2}{*}{ 1200350B } & & 04/30/02-1120 CST-in & \multirow[t]{6}{*}{$1.2(3.8)$} & \multirow{6}{*}{$\begin{array}{l}3582598,13908337- \\
\text { about } 670 \mathrm{ft} \text { from channel } \\
\text { center line }\end{array}$} \\
\hline & & 05/01/02-1615 CST-out & & \\
\hline \multirow[t]{2}{*}{ 1210350B } & & 05/01/02-1700 CST-in & & \\
\hline & & 05/03/02-1320 CST-out & & \\
\hline \multirow[t]{2}{*}{$1230350 \mathrm{~B}$} & & 05/03/02-1425 CST-in & & \\
\hline & & 05/04/02-0725 CST-out & & \\
\hline
\end{tabular}




\begin{tabular}{|c|c|c|c|c|}
\hline \multicolumn{5}{|c|}{$\begin{array}{l}\text { Table } 2 \\
\text { Capacitance Gage Descriptions }\end{array}$} \\
\hline Array/Gage & Location & Time In/Out Water & $\begin{array}{l}\text { Depth, } m(f t) \\
\text { below mlt }\end{array}$ & $\begin{array}{l}\text { State Plane, NAD83, } \\
\text { Texas South Central } \\
4204\end{array}$ \\
\hline \multirow[t]{4}{*}{$1200522 B$} & \multirow[t]{12}{*}{ South } & 04/30/02-1550 CST-in & \multirow{6}{*}{$\begin{array}{l}\text { Near } \\
\text { Channel = } \\
1.3(4.4),\end{array}$} & \multirow{6}{*}{$\begin{array}{l}\text { Near Channel- } \\
3570930,13869253\end{array}$} \\
\hline & & 05/01/02-1330 CST-out & & \\
\hline & & 04/30/02-1550 CST-in & & \\
\hline & & 05/01/02-1330 CST-out & & \\
\hline \multirow[t]{4}{*}{ 1210520B } & & 05/01/02-1430 CST-in & & \\
\hline & & 05/03/02-0950 CST-out & & \\
\hline & & 05/01/02-1430 CST-in & \multirow{6}{*}{$\begin{array}{l}\text { Near } \\
\text { Shoreline = } \\
0.8(2.5)\end{array}$} & \multirow{6}{*}{$\begin{array}{l}\text { Near Bank- 3570988, } \\
13869290\end{array}$} \\
\hline & & 05/03/02-0950 CST-out & & \\
\hline \multirow[t]{4}{*}{ 1220526B } & & 05/03/02-0945 CST-in & & \\
\hline & & 05/04/02-0900 CST-out & & \\
\hline & & 05/03/02-0945 CST-in & & \\
\hline & & 05/04/02-0900 CST-out & & \\
\hline \multirow[t]{6}{*}{ 1210526B } & \multirow[t]{12}{*}{ North } & 05/01/02-1045 CST-in & \multirow{12}{*}{$\begin{array}{l}\text { Near } \\
\text { Channel = } \\
\text { Middle = } \\
\text { Near } \\
\text { Shoreline = } \\
0.3(1.0)\end{array}$} & \multirow{4}{*}{$\begin{array}{l}\text { Near Channel- } \\
3583596,13908863\end{array}$} \\
\hline & & 05/02/02-0845 CST-out & & \\
\hline & & 05/01/02-1045 CST-in & & \\
\hline & & 05/02/02-0845 CST-out & & \\
\hline & & 05/01/02-1045 CST-in & & \multirow{4}{*}{$\begin{array}{l}\text { Middle- } 3583647 \\
13908823\end{array}$} \\
\hline & & 05/02/02-0845 CST-out & & \\
\hline \multirow[t]{6}{*}{ 1220522B } & & 05/02/02-1045 CST-in & & \\
\hline & & 05/04/02-1015 CST-out & & \\
\hline & & 05/02/02-1045 CST-in & & \multirow{4}{*}{$\begin{array}{l}\text { Near Bank- 3583676, } \\
13908800\end{array}$} \\
\hline & & 05/04/02-1015 CST-out & & \\
\hline & & 05/02/02-1045 CST-in & & \\
\hline & & 05/04/02-1015 CST-out & & \\
\hline
\end{tabular}




\begin{tabular}{|c|c|c|c|c|c|c|}
\hline $\begin{array}{l}\text { Ship Name, Type } \\
\mathrm{T}=\text { tanker, B = bulk }\end{array}$ & $\begin{array}{l}\text { Date (2002), } \\
\text { Time }\end{array}$ & Dir & $\begin{array}{l}\text { Length, } \mathrm{m} \\
\text { (ft) }\end{array}$ & Beam, $m(\mathrm{ft})$ & Draft, $\mathrm{m}(\mathrm{ft})$ & Tide mlt, $\mathrm{m}$ (ft) \\
\hline Eagle Augusta, $T$ & 29 Apr, 1624 & Out & $243.6(799)$ & $42.4(139)$ & $8.5(28)$ & Ebb, $0.92(3.03)$ \\
\hline Noblesse, $B$ & 29 Apr, 1702 & In & $158.8(521)$ & $22.6(74)$ & $6.1(20)$ & Ebb, 0.93 (3.05) \\
\hline Dafnis, B & 29 Apr, 1740 & Out & 160.1(525) & $23.5(77)$ & $7.0(23)$ & Ebb, $0.88(2.88)$ \\
\hline Nordlight, $T$ & $30 \mathrm{Apr}, 0820$ & Out & $244.2(801)$ & $42.1(138)$ & $9.1(30)$ & Flood, 0.90 (2.98) \\
\hline Frankopan, $T$ & $30 \mathrm{Apr}, 0945$ & Out & $244.5(802)$ & $39.3(129)$ & $9.1(30)$ & Slack, 0.94 (3.10) \\
\hline Minerva Joanna, $T$ & 30 Apr, 1015 & Out & $182.9(600)$ & $32.3(106)$ & $9.1(30)$ & Slack, 0.94 (3.08) \\
\hline Star America, B & $30 \mathrm{Apr}, 1350$ & $\ln$ & $169.5(556)$ & $26.5(87)$ & $8.2(27)$ & Slack, $0.95(3.13)$ \\
\hline Zeebruggee, LGP & $30 \mathrm{Apr}, 1400$ & $\ln$ & $159.4(523)$ & $24.3(80)$ & $10.1(33)$ & Slack, 0.97 (3.21) \\
\hline Bornes, $T$ & $30 \mathrm{Apr}, 1440$ & $\ln$ & $243.9(800)$ & $42.1(138)$ & $11.6(38)$ & Slack, 0.97 (3.19) \\
\hline Bernhard Oldendorf, $B$ & $30 \mathrm{Apr}, 1635$ & $\ln$ & $245.1(804)$ & $32.3(106)$ & $9.5(31)$ & Slack, 0.95 (3.13) \\
\hline Kite Arrow, $B$ & $30 \mathrm{Apr}, 2135$ & Out & $199.7(655)$ & $32.3(106)$ & $10.1(33)$ & Ebb, $0.83(2.73)$ \\
\hline Sunor, $B$ & $30 \mathrm{Apr}, 2300$ & Out & $180.1(591)$ & $30.5(100)$ & $11.6(38)$ & Ebb, $0.74(2.43)$ \\
\hline Anette, $T$ & $30 \mathrm{Apr}, 2350$ & $\ln$ & $224.7(737)$ & $32.3(106)$ & $11.6(38)$ & Ebb, $0.62(2.04)$ \\
\hline Noblesse, $B$ & 1 May, 0215 & Out & $158.8(521)$ & $22.6(74)$ & $6.1(20)$ & Ebb, 0.59 (1.96) \\
\hline Olga Topic, B & 1 May, 0515 & Out & $185.7(609)$ & $30.5(100)$ & $7.9(26)$ & Flood, 0.77 (2.55) \\
\hline Saraband, $T$ & 1 May, 0930 & $\ln$ & $182.6(599)$ & $32.0(105)$ & $8.2(27)$ & Flood, 0.97 (3.18) \\
\hline Zrinkski, T & 1 May, 1225 & In & $244.5(802)$ & $39.3(129)$ & $11.9(39)$ & Slack, $1.02(3.37)$ \\
\hline Astro Antares, $T$ & 1 May, 1345 & $\ln$ & $248.2(814)$ & $43.3(142)$ & $11.9(39)$ & Slack, 1.03 (3.38) \\
\hline Pacific Sapphire, $T$ & 1 May, 1305 & $\ln$ & $247.0(810)$ & $41.7(137)$ & $12.2(40)$ & Slack, 0.96 (3.16) \\
\hline Project Europa, $H$ & 1 May, 1530 & $\ln$ & $139.0(456)$ & $22.9(75)$ & $7.3(24)$ & Ebb, $0.98(3.24)$ \\
\hline S/R Charleston, $T$ & 1 May, 2135 & $\ln$ & $193.9(636)$ & $32.3(106)$ & $8.8(29)$ & Ebb, 0.82 (2.69) \\
\hline Milagro, $T$ & 2 May, 0349 & Out & $196.0(643)$ & $24.3(80)$ & $8.8(29)$ & Ebb, $0.66(2.17)$ \\
\hline Bornes, $T$ & 2 May, 0805 & Out & $243.9(800)$ & $42.1(138)$ & $9.8(32)$ & Flood, $0.71(2.34)$ \\
\hline Jo Lonn, $T$ & 2 May, 1100 & In & $175.0(574)$ & $32.0(105)$ & $9.5(31)$ & Slack, 0.97 (3.21) \\
\hline Eagle Carina, $T$ & 2 May, 1215 & $\ln$ & $247.0(810)$ & $42.1(138)$ & $10.7(35)$ & Slack, 0.99 (3.26) \\
\hline Bunga Kelana Dua, T & 2 May, 1230 & $\ln$ & $243.9(800)$ & $42.1(138)$ & $11.6(38)$ & Slack, 0.99 (3.26) \\
\hline Grand Orchid, B & 2 May, 1450 & $\ln$ & $189.9(623)$ & $31.1(102)$ & $11.3(37)$ & Ebb, 0.97 (3.21) \\
\hline Olga Topic, B & 2 May, 1815 & Out & $185.6(609)$ & $30.5(100)$ & $11.6(38)$ & Ebb, $0.89(2.94)$ \\
\hline Bernhard Oldendorf, B & 2 May, 1920 & Out & $245.1(804)$ & $32.3(106)$ & $11.6(38)$ & Ebb, $0.84(2.76)$ \\
\hline Zeebruggee, LGP & 2 May, 1935 & Out & $159.4(523)$ & $24.3(80)$ & $7.0(23)$ & Ebb, 0.85 (2.90) \\
\hline Anette, $T$ & 3 May, 0215 & Out & $224.7(737)$ & $32.3(106)$ & $8.5(28)$ & Ebb, $0.72(2.36)$ \\
\hline Astro Antares, $T$ & 3 May, 0930 & Out & $248.2(814)$ & $43.3(142)$ & $8.8(29)$ & Flood, $0.79(2.60)$ \\
\hline Genmar Alexandra, $T$ & 3 May, 1305 & In & $241.5(792)$ & $42.1(138)$ & $11.6(38)$ & Slack, $0.93(3.05)$ \\
\hline Eagle Subaru, $T$ & 3 May, 1320 & $\ln$ & $247.0(810)$ & $42.1(138)$ & $12.2(40)$ & Slack, 0.92 (3.02) \\
\hline Alderbaran, $T$ & 3 May, 1335 & $\ln$ & $243.9(800)$ & $39.9(131)$ & $10.7(35)$ & Slack, 0.93 (3.05) \\
\hline Eagle Auriga, $T$ & 3 May, 1620 & $\ln$ & $241.5(792)$ & $42.1(138)$ & $11.9(39)$ & Ebb, $0.84(2.78)$ \\
\hline Shetland, Lig Gas & 3 May, 1940 & $\ln$ & $153.4(503)$ & $25.0(82)$ & $7.0(23)$ & Ebb, $0.84(2.77)$ \\
\hline Jo Lonn, $T$ & 3 May, 2055 & Out & $175.3(575)$ & $32.0(105)$ & $10.1(33)$ & Ebb, $0.86(2.83)$ \\
\hline Stolt Tarus, $T$ & 3 May, 2150 & Out & $123.5(405)$ & $20.4(67)$ & $10.1(33)$ & Ebb, $0.84(2.78)$ \\
\hline Pacific Sapphire, $T$ & 4 May, 0735 & Out & $247.0(810)$ & $41.7(137)$ & $8.5(28)$ & Slack, 0.58 (1.93) \\
\hline
\end{tabular}




\begin{tabular}{|c|c|c|c|c|c|c|c|c|c|c|c|c|}
\hline \multicolumn{13}{|c|}{$\begin{array}{l}\text { Table } 4 \\
\text { Drawdown and Surge at North Site }\end{array}$} \\
\hline Ship Name & \begin{tabular}{|l|} 
Date \\
$(2002)$
\end{tabular} & Dir & $\begin{array}{l}\text { Drawdown } \\
\text { Pressure } \\
\text { Cell } 349 \\
\mathrm{~m}(\mathrm{ft}) \\
\end{array}$ & $\begin{array}{l}\text { Drawdown } \\
\text { Pressure } \\
\text { Cell } 350 \\
\mathrm{~m}(\mathrm{ft}) \\
\end{array}$ & $\begin{array}{l}\text { Drawdown } \\
\text { Capacitance } \\
\text { Cell 526, } \\
\text { Bank, m (ft) } \\
\end{array}$ & $\begin{array}{l}\text { Drawdown } \\
\text { Capacitance } \\
\text { Cell 526, } \\
\text { Middle, m (ft) } \\
\end{array}$ & \begin{tabular}{|l} 
Drawdown \\
Capacitance \\
Cell 526, \\
Channel, \\
m (ft) \\
\end{tabular} & \begin{tabular}{|l} 
Surge \\
Pressure \\
Cell 349 \\
$\mathrm{~m}(\mathrm{ft})$ \\
\end{tabular} & \begin{tabular}{|l} 
Surge \\
Pressure \\
Cell 350 \\
$\mathrm{~m}(\mathrm{ft})$ \\
\end{tabular} & \begin{tabular}{|l} 
Surge \\
Capacitance \\
Cell 526, \\
bank, m (ft) \\
\end{tabular} & \begin{tabular}{|l|} 
Surge \\
Capacitance \\
Cell 526, \\
Middle, \\
m (ft) \\
\end{tabular} & \begin{tabular}{|l|} 
Surge \\
Capacitance \\
Cell 526, \\
Channel, \\
m (ft) \\
\end{tabular} \\
\hline Nordlight & 30-Apr & Out & $\mathrm{NA}^{1}$ & NA & NA & NA & NA & NA & NA & NA & NA & NA \\
\hline Frankopan & 30-Apr & Out & NA & NA & NA & NA & NA & NA & NA & NA & NA & NA \\
\hline Minerva Joanna & 30-Apr & Out & NA & NA & NA & NA & NA & NA & NA & NA & NA & NA \\
\hline Star America & 30-Apr & $\ln$ & $0.60(2.0)$ & $0.60(2.0)$ & NA & NA & NA & $0.05(0.2)$ & $0.0(0.00)$ & NA & NA & NA \\
\hline Zeebruggee & 30-Apr & $\ln$ & $1.20(3.9)$ & $0.80(2.6)$ & NA & NA & NA & $0.10(0.3)$ & $0.20(0.7)$ & NA & NA & NA \\
\hline Bornes & 30-Apr & $\ln$ & & & NA & NA & NA & NA & NA & NA & NA & NA \\
\hline $\begin{array}{l}\text { Bernhard } \\
\text { Oldendorf }\end{array}$ & 30-Apr & $\ln$ & $1.35(4.4)$ & $0.95(3.1)$ & NA & NA & NA & $0.25(0.8)$ & $0.20(0.7)$ & NA & NA & NA \\
\hline Kite Arrow & 30-Apr & Out & & & NA & NA & NA & & & NA & NA & NA \\
\hline Sunor & $30-A p r$ & Out & $0.30(1.0)$ & $0.30(1.0)$ & NA & NA & NA & $0.05(0.2)$ & $0.35(1.1)$ & NA & NA & NA \\
\hline Anette & 30-Apr & $\ln$ & $0.80(2.6)$ & $0.50(1.6)$ & NA & NA & NA & $0.0(0.0)$ & $0.0(0.0)$ & NA & NA & NA \\
\hline Noblesse & 1-May & Out & & & NA & NA & NA & NA & NA & NA & NA & NA \\
\hline Olga Topic & 1-May & Out & & & NA & NA & NA & NA & NA & NA & NA & NA \\
\hline Saraband & 1-May & $\ln$ & $0.70(2.3)$ & $0.60(2.0)$ & NA & NA & NA & $0.10(0.3)$ & $0.10(0.3)$ & NA & NA & NA \\
\hline Zrinski & 1-May & $\ln$ & $0.55(1.8)$ & $1.50(4.9)$ & $0.75(2.5)$ & $0.75(2.5)$ & $0.85(2.8)$ & $0.20(0.7)$ & $0.20(0.7)$ & $0.65(2.1)$ & $0.40(1.3)$ & $0.40(1.3)$ \\
\hline Astro Antares & 1-May & $\ln$ & $1.00(3.3)$ & $1.80(5.9)$ & NA & NA & NA & $0.25(0.8)$ & $0.35(1.1)$ & NA & NA & NA \\
\hline Pacific Sapphire & 1-May & $\ln$ & $0.75(2.5)$ & $1.75(5.7)$ & $0.95(3.1)$ & $0.80(2.6)$ & $0.95(3.1)$ & $0.25(0.8)$ & $0.30(1.0)$ & $0.4(1.3)$ & $0.3(1.0)$ & $0.35(1.1)$ \\
\hline Project Europa & 1-May & $\ln$ & $0.50(1.6)$ & $1.25(4.1)$ & $0.80(2.6)$ & $0.60(2.0)$ & $0.50(1.6)$ & $0.05(0.2)$ & $0.05(0.2)$ & $0.20(0.7)$ & $0.15(0.5)$ & $0.15(0.5)$ \\
\hline S/R Charleston & 1-May & $\ln$ & $0.70(2.3)$ & $0.80(2.6)$ & $0.70(2.3)$ & $0.55(1.8)$ & $0.70(2.3)$ & $0.15(0.5)$ & $0.0(0.0)$ & $0.25(0.8)$ & $0.1(0.3)$ & $0.25(0.8)$ \\
\hline Milagro & 2-May & Out & $0.50(1.6)$ & $0.65(2.1)$ & $0.60(2.0)$ & $0.45(1.5)$ & $0.60(2.0)$ & $0.05(0.2)$ & $0.30(1.0)$ & 0.35 (1.1) & $0.25(0.8)$ & $0.35(1.1)$ \\
\hline
\end{tabular}




\begin{tabular}{|c|c|c|c|c|c|c|c|c|c|c|c|c|}
\hline \multicolumn{13}{|c|}{ Table 4 (Concluded) } \\
\hline Ship Name & \begin{tabular}{|l} 
Date \\
$(2002)$ \\
\end{tabular} & Dir & \begin{tabular}{|l} 
Drawdown \\
Pressure \\
Cell 349 \\
$\mathrm{~m}(\mathrm{ft})$ \\
\end{tabular} & \begin{tabular}{|l} 
Drawdown \\
Pressure \\
Cell 350 \\
$\mathrm{~m}(\mathrm{ft})$ \\
\end{tabular} & $\begin{array}{l}\text { Drawdown } \\
\text { Capacitance } \\
\text { Cell 526, } \\
\text { Bank, m (ft) } \\
\end{array}$ & $\begin{array}{l}\text { Drawdown } \\
\text { Capacitance } \\
\text { Cell 526, } \\
\text { Middle, } \mathrm{m} \text { (ft) } \\
\end{array}$ & $\begin{array}{l}\text { Drawdown } \\
\text { Capacitance } \\
\text { Cell 526, } \\
\text { Channel, } \\
\text { m (ft) } \\
\end{array}$ & \begin{tabular}{|l} 
Surge \\
Pressure \\
Cell 349 \\
$\mathrm{~m}(\mathrm{ft})$ \\
\end{tabular} & \begin{tabular}{|l} 
Surge \\
Pressure \\
Cell 350 \\
$\mathrm{~m}(\mathrm{ft})$ \\
\end{tabular} & \begin{tabular}{|l} 
Surge \\
Capacitance \\
Cell 526, \\
Bank, m (ft) \\
\end{tabular} & \begin{tabular}{|l} 
Surge \\
Capacitance \\
Cell 526, \\
Middle, \\
m (ft) \\
\end{tabular} & \begin{tabular}{|l} 
Surge \\
Capacitance \\
Cell 526, \\
Channel, \\
m (ft) \\
\end{tabular} \\
\hline Bornes & 2-May & Out & $0.70(2.3)$ & $0.75(2.5)$ & $0.65(2.1)$ & $0.50(1.6)$ & $0.60(2.0)$ & $0.35(1.1)$ & $0.50(1.6)$ & NA & NA & NA \\
\hline Jo Lonn & 2-May & In & $0.75(2.5)$ & $0.70(2.3)$ & $0.7(2.3)$ & $0.7(2.3)$ & $0.75(2.5)$ & $0.05(0.2)$ & $0.05(0.2)$ & $0.3(1.0)$ & $0.25(0.8)$ & $0.4(1.3)$ \\
\hline Eagle Carina & 2-May & $\ln$ & $0.65(2.1)$ & $0.70(2.3)$ & $0.70(2.3)$ & $0.75(2.5)$ & $0.75(2.5)$ & $0.20(0.7)$ & $0.05(0.2)$ & $0.30(1.0)$ & $0.3(1.0)$ & $0.35(1.1)$ \\
\hline \begin{tabular}{|l|} 
Bunga Kelana \\
Dua
\end{tabular} & 2-May & $\ln$ & NA & NA & NA & NA & NA & NA & NA & NA & NA & NA \\
\hline Grand Orchid & 2-May & In & NA & NA & NA & NA & NA & NA & NA & NA & NA & NA \\
\hline Olga Topic & 2-May & Out & NA & NA & NA & NA & NA & NA & NA & NA & NA & NA \\
\hline \begin{tabular}{|l|} 
Bernhard \\
Oldendorf \\
\end{tabular} & 2-May & Out & $0.55(1.8)$ & $0.45(1.5)$ & $0.60(2.0)$ & $0.65(2.1)$ & $0.60(2.0)$ & $0.0(0.0)$ & $0.45(1.5)$ & NA & NA & NA \\
\hline Zeebruggee & 2-May & Out & NA & NA & $0.55(1.8)$ & $0.55(1.8)$ & $0.55(1.8)$ & NA & NA & $0.25(0.8)$ & $0.25(0.8)$ & $0.2(0.7)$ \\
\hline Anette & 3-May & Out & NA & NA & NA & NA & NA & NA & NA & NA & NA & NA \\
\hline Astro Antares & 3-May & Out & $1.05(3.4)$ & $0.90(3.0)$ & $0.55(1.8)$ & $0.60(2.0)$ & $0.75(2.5)$ & $0.0(0.0)$ & $0.60(2.0)$ & $0.4(1.3)$ & $0.4(1.3)$ & $0.45(1.5)$ \\
\hline \begin{tabular}{|l} 
Genmar \\
Alexandra \\
\end{tabular} & 3-May & $\ln$ & $0.35(1.1)$ & $0.35(1.1)$ & $0.40(1.3)$ & $0.60(2.0)$ & $0.45(1.5)$ & $0.10(0.3)$ & $0.10(0.3)$ & $0.3(1.0)$ & $0.3(1.0)$ & $0.25(0.8)$ \\
\hline Eagle Subaru & 3-May & In & NA & NA & $0.4(1.3)$ & NA & $0.35(1.1)$ & NA & NA & $0.25(0.8)$ & NA & $0.2(0.7)$ \\
\hline Aldebaran & 3-May & $\ln$ & NA & NA & $0.3(1.0)$ & NA & $0.3(1.0)$ & NA & NA & $0.2(0.7)$ & NA & $0.15(0.5)$ \\
\hline Eagle Auriga & 3-May & $\ln$ & $0.40(1.3)$ & $0.45(1.5)$ & $0.60(2.0)$ & $0.60(2.0)$ & $0.55(1.8)$ & $0.05(0.2)$ & $0.20(0.7)$ & $0.35(1.1)$ & $0.4(1.3)$ & $0.25(0.8)$ \\
\hline Sthetland & 3-May & In & $0.60(2.0)$ & $0.35(1.1)$ & $0.40(1.3)$ & $0.55(1.8)$ & $0.45(1.5)$ & $0.0(0.0)$ & $0.10(0.3)$ & $0.35(1.1)$ & $0.3(1.0)$ & $0.25(0.8)$ \\
\hline Jo Lonn & 3-May & Out & $0.50(1.6)$ & $0.60(2.0)$ & & & & $0.05(0.2)$ & $0.45(1.5)$ & NA & NA & NA \\
\hline Stolt Tarus & 3-May & Out & NA & NA & NA & NA & NA & NA & NA & NA & NA & NA \\
\hline Pacific Sapphire & 4-May & Out & NA & NA & $0.85(2.8)$ & $0.65 \mathrm{c}(2.1)$ & $0.35 c(1.1)$ & NA & NA & $0.5(1.6)$ & NA & NA \\
\hline
\end{tabular}




\begin{tabular}{|c|c|c|c|c|c|c|c|c|c|c|}
\hline \multicolumn{11}{|c|}{$\begin{array}{l}\text { Table } 5 \\
\text { Drawdown and Surge at South Site }\end{array}$} \\
\hline Ship Name & \begin{tabular}{|l} 
Date \\
$(2002$
\end{tabular} & Direction & \begin{tabular}{|l} 
Drawdown \\
Pressure \\
Cell 346 \\
$\mathrm{~m}(\mathrm{ft})$ \\
\end{tabular} & \begin{tabular}{|l} 
Drawdown \\
Pressure \\
Cell 347 \\
$\mathrm{m}(\mathrm{ft})$ \\
\end{tabular} & $\begin{array}{l}\text { Drawdown } \\
\text { Capacitance } \\
\text { Cell 522, } \\
\text { Channel, m (ft) } \\
\end{array}$ & \begin{tabular}{|l} 
Drawdown \\
Capacitance \\
Cell 522, \\
Bank, m (ft) \\
\end{tabular} & \begin{tabular}{|l|} 
Surge Pressure \\
Cell 346 \\
$\mathrm{m}(\mathrm{ft})$
\end{tabular} & \begin{tabular}{|l|} 
Surge Pressure \\
Cell 347 \\
$\mathrm{m}$ (ft)
\end{tabular} & $\begin{array}{l}\text { Surge } \\
\text { Capacitance } \\
\text { Cell 522, } \\
\text { Channel, m (ft) } \\
\end{array}$ & \begin{tabular}{|l} 
Surge \\
Capacitance \\
Cell 522, Bank \\
$\mathrm{m}$ (ft) \\
\end{tabular} \\
\hline Nordlight & 30-Apr & Out & $0.90 \mathrm{c}(3.0)$ & $1.15(3.8)$ & $N A^{1}$ & NA & $0.40(1.3)$ & $0.45(1.5)$ & NA & NA \\
\hline Frankopan & 30-Apr & Out & $0.65(2.1)$ & $0.70(2.3)$ & NA & NA & $0.30(1.0)$ & $0.25(0.8)$ & NA & NA \\
\hline \begin{tabular}{|l|} 
Minerva \\
Joanna
\end{tabular} & 30-Apr & Out & $0.70(2.3)$ & $0.70(2.3)$ & NA & NA & $0.50(1.6)$ & $0.4(1.3)$ & NA & NA \\
\hline Star America & 30-Apr & In & $0.90(3.0)$ & $1.00(3.3)$ & NA & NA & $0.35(1.1)$ & $0.50(1.6)$ & NA & NA \\
\hline Zeebruggee & 30-Apr & In & $0.90 \mathrm{c}(3.0)$ & $0.90(3.0)$ & NA & NA & $0.45(1.5)$ & $0.50(1.6)$ & NA & NA \\
\hline Bornes & 30-Apr & $\ln$ & $0.85 \mathrm{c}(2.8)$ & $1.10(3.6)$ & NA & NA & $0.30(1.0)$ & $0.10(0.3)$ & NA & NA \\
\hline \begin{tabular}{|l|} 
Bernhard \\
Oldendorf \\
\end{tabular} & 30-Apr & $\ln$ & $0.75 \mathrm{c}(2.5)$ & $0.95(3.1)$ & $1.05(3.4)$ & $0.85 \mathrm{c}(2.8)$ & $0.15(0.5)$ & $0.35(1.1)$ & $0.45(1.5)$ & $0.85(2.8)$ \\
\hline Kite Arrow & 30-Apr & Out & $0.60 \subset(2.0)$ & $0.80(2.6)$ & $0.60(2.0)$ & $0.55 \mathrm{c}(1.8)$ & $0.4(1.3)$ & $0.55(1.8)$ & $0.4(1.3)$ & $0.45(1.5)$ \\
\hline Sunor & 30-Apr & Out & $0.40(1.3)$ & $0.55(1.8)$ & NA & NA & $0.25(0.8)$ & $0.3(1.0)$ & NA & NA \\
\hline Anette & 30-Apr & $\ln$ & $0.50 \mathrm{c}(1.6)$ & $0.95(3.1)$ & $0.70(2.3)$ & $0.45 c(1.5)$ & $0.20(0.7)$ & $0.45(1.5)$ & $0.3(1.0)$ & $0.45(1.5)$ \\
\hline Noblesse & 1-May & Out & $0.25(0.8)$ & $0.40(1.3)$ & NA & NA & $0.20(0.7)$ & $0.35(1.1)$ & $0.25(0.8)$ & $0.20(0.7)$ \\
\hline Olga Topic & 1-May & Out & $0.65(2.1)$ & $0.50(1.6)$ & $0.4(1.3)$ & $0.55(1.8)$ & $0.35(1.1)$ & $0.35(1.1)$ & $0.30(1.0)$ & $0.35(1.1)$ \\
\hline Saraband & 1-May & In & $0.90(3.0)$ & $0.85(2.8)$ & NA & NA & $0.40(1.3)$ & $0.40(1.3)$ & NA & NA \\
\hline Zrinski & 1-May & In & $0.70(2.3)$ & $0.80(2.6)$ & $0.60(2.0)$ & $0.70(2.3)$ & $0.30(1.1)$ & $0.10(0.3)$ & $0.30(1.0)$ & NA \\
\hline Astro Antares & 1-May & $\ln$ & $0.9 c(3.0)$ & $1.0(3.3)$ & NA & NA & $0.25(0.8)$ & $0.10(0.3)$ & NA & NA \\
\hline \begin{tabular}{|l|} 
Pacific \\
Sapphire \\
\end{tabular} & 1-May & $\ln$ & $0.90(3.0)$ & $0.95(3.1)$ & $1.05(3.4)$ & 0.95 c (3.1) & $0.3(1.0)$ & $0.15(0.5)$ & $0.25(0.8)$ & $0.3(1.0)$ \\
\hline $\begin{array}{l}\text { Project } \\
\text { Europa }\end{array}$ & 1-May & $\ln$ & $0.70(2.3)$ & $0.55(1.8)$ & NA & NA & $0.35(1.1)$ & $0.4(1.3)$ & NA & NA \\
\hline \begin{tabular}{|l|} 
S/R \\
Charleston \\
\end{tabular} & 1-May & In & $0.75(2.5)$ & $1.10(3.6)$ & $0.95(3.1)$ & $0.75 \mathrm{c}(2.5)$ & $0.15(0.5)$ & $0.35(1.1)$ & $0.25(0.8)$ & NA \\
\hline Milagro & 2-May & Out & $0.65(2.1)$ & $0.65(2.1)$ & $0.60(2.0)$ & $0.55 \mathrm{c}(1.8)$ & $0.45(1.5)$ & $0.50(1.6)$ & $0.50(1.6)$ & $0.4(1.3)$ \\
\hline Bornes & 2-May & Out & $0.70(2.3)$ & $0.80(2.6)$ & $0.75(2.5)$ & NA & $0.50(1.6)$ & $0.45(1.5)$ & $0.40(1.3)$ & NA \\
\hline Jo Lonn & 2-May & In & $0.45(1.5)$ & $0.75(2.5)$ & $0.50(1.6)$ & $0.65(2.1)$ & NA & $0.45(1.5)$ & $0.40(1.3)$ & NA \\
\hline & & & & & & & & & & (Continueo \\
\hline
\end{tabular}




\begin{tabular}{|c|c|c|c|c|c|c|c|c|c|c|}
\hline Ship Name & \begin{tabular}{|l} 
Date \\
$(2002$ \\
\end{tabular} & Direction & \begin{tabular}{|l|} 
Drawdown \\
Pressure \\
Cell 346 \\
$\mathrm{~m}(\mathrm{ft})$ \\
\end{tabular} & \begin{tabular}{|l|} 
Drawdown \\
Pressure \\
Cell 347 \\
$\mathrm{~m}(\mathrm{ft})$ \\
\end{tabular} & \begin{tabular}{|l|} 
Drawdown \\
Capacitance \\
Cell 522, \\
Channel, m (ft) \\
\end{tabular} & \begin{tabular}{|l} 
Drawdown \\
Capacitance \\
Cell 522, Bank, \\
$\mathrm{m}(\mathrm{ft})$ \\
\end{tabular} & $\begin{array}{l}\text { Surge Pressure } \\
\text { Cell } 346 \\
\mathrm{~m}(\mathrm{ft}) \\
\end{array}$ & $\begin{array}{l}\text { Surge Pressure } \\
\text { Cell 347 } \\
\mathrm{m}(\mathrm{ft}) \\
\end{array}$ & \begin{tabular}{|l} 
Surge \\
Capacitance \\
Cell 522, \\
Channel, m (ft) \\
\end{tabular} & \begin{tabular}{|l|} 
Surge \\
Capacitance \\
Cell 522, Bank, \\
$\mathrm{m}$ (ft) \\
\end{tabular} \\
\hline Eagle Carina & 2-May & $\ln$ & $0.65(2.1)$ & $0.65(2.1)$ & $0.60(2.0)$ & NA & $0.25(0.8)$ & $0.10(0.3)$ & $0.1(0.3)$ & NA \\
\hline \begin{tabular}{|l|} 
Bunga Kelana \\
Dua
\end{tabular} & 2-May & $\ln$ & $0.45(1.5)$ & $0.60(2.0)$ & $0.45(1.5)$ & $0.55(1.8)$ & $0.15(0.5)$ & $0.10(0.3)$ & $0.05(0.2)$ & $0.15(0.5)$ \\
\hline Grand Orchid & 2-May & $\ln$ & $0.50(1.6)$ & $0.50(1.6)$ & $0.45(1.5)$ & $0.60(2.0)$ & $0.20(0.7)$ & $0.10(0.3)$ & $0.20(0.7)$ & $0.40(1.3)$ \\
\hline Olga Topic & 2-May & Out & $0.40(1.3)$ & $0.55(1.8)$ & $0.40(1.3)$ & $0.50(1.6)$ & $0.15(0.5)$ & $0.20(0.7)$ & $0.20(0.7)$ & $0.25(0.8)$ \\
\hline $\begin{array}{l}\text { Bernhard } \\
\text { Oldendorf }\end{array}$ & 2-May & Out & $0.75(2.5)$ & $0.95(3.1)$ & $0.75(2.5)$ & $0.80 \mathrm{c}(2.6)$ & $0.45(1.5)$ & $0.45(1.5)$ & $0.45(1.5)$ & NA \\
\hline Zeebruggee & 2-May & Out & $0.55(1.8)$ & $0.75(2.5)$ & $0.45(1.5)$ & $0.65(2.1)$ & $0.55(1.8)$ & $0.60(2.0)$ & $0.5(1.6)$ & NA \\
\hline Anette & 3-May & Out & $0.60(2.0)$ & $0.65(2.1)$ & $0.50(1.6)$ & $0.50 \mathrm{c}(1.6)$ & $0.40(1.3)$ & $0.45(1.5)$ & NA & NA \\
\hline Astro Antares & 3-May & Out & $0.40(1.3)$ & $0.75(2.5)$ & $0.45(1.5)$ & $0.60(2.0)$ & $0.20(0.7)$ & $0.3(1.0)$ & $0.3(1.0)$ & NA \\
\hline \begin{tabular}{|l|} 
Genmar \\
Alexandra \\
\end{tabular} & 3-May & $\ln$ & $0.30(1.0)$ & $0.60(2.0)$ & $0.50(1.5)$ & $0.60(2.0)$ & $0.25(0.8)$ & $0.20(0.7)$ & $0.05(0.2)$ & $0.20(0.7)$ \\
\hline Eagle Subaru & 3-May & $\ln$ & $0.40(1.3)$ & $0.45(1.5)$ & $0.30(1.0)$ & $0.40(1.3)$ & $0.20(0.7)$ & $0.05(0.2)$ & $0.1(1.3)$ & $0.10(0.3)$ \\
\hline Aldebaran & 3-May & In & $0.65(2.1)$ & $0.60(2.0)$ & $0.7(2.3)$ & $0.8(2.6)$ & $0.20(0.7)$ & $0.10(0.3)$ & $0.15(0.5)$ & NA \\
\hline Eagle Auriga & 3-May & $\ln$ & $0.65(2.1)$ & $0.75(2.5)$ & $0.65(2.1)$ & $0.65(2.1)$ & $0.15(0.5)$ & $0.05(0.2)$ & $0.05(0.2)$ & $0.1(0.3)$ \\
\hline Sthetland & 3-May & $\ln$ & $0.95(3.1)$ & $0.95(3.1)$ & $0.65(2.1)$ & $0.85 \mathrm{c}(2.8)$ & $0.50(1.6)$ & $0.55(1.8)$ & $0.55(1.8)$ & NA \\
\hline Jo Lonn & 3-May & Out & $0.55(1.8)$ & $0.6592 .1)$ & $0.4(1.3)$ & $0.5(1.6)$ & $0.35(1.1)$ & $0.40(1.3)$ & $0.40(1.3)$ & NA \\
\hline Stolt Tarus & 3-May & Out & $0.50(1.6)$ & $0.60(2.0)$ & $0.35(1.1)$ & $0.55(1.8)$ & $0.45(1.5)$ & $0.50(1.6)$ & $0.40(1.3)$ & NA \\
\hline $\begin{array}{l}\text { Pacific } \\
\text { Sapphire }\end{array}$ & 4-May & Out & $0.80(2.6)$ & $0.90(3.0)$ & $0.85(2.8)$ & $0.65 c(2.1)$ & $0.6(2.0)$ & $0.6(2.0)$ & $0.6(2.0)$ & NA \\
\hline
\end{tabular}




\begin{tabular}{|c|c|}
\hline \multicolumn{2}{|c|}{$\begin{array}{l}\text { Table } 6 \\
\text { Characteristics of Pacific Sapphire Passage on } 1 \text { May } 2002\end{array}$} \\
\hline Characteristic & Dimension \\
\hline Beam, ft & 137 \\
\hline Length, $\mathrm{ft}$ & 810 \\
\hline Draft, $\mathrm{ft}$ & 40 \\
\hline Ship $\mathrm{x}$-section area, sq ft & 5480 \\
\hline Speed at north and south sites, knots relative to ground & $8.3,8.6$ \\
\hline Water level, ft mlt (tide) & 3.16 (slack) \\
\hline Shoreline drawdown at north and south sites, $\mathrm{ft}$ & $2.9,3.3$ \\
\hline Shoreline surge at north and south sites, $\mathrm{ft}$ & $1.3,1.0$ \\
\hline
\end{tabular}

\begin{tabular}{|c|c|c|c|c|c|c|}
\hline \multicolumn{7}{|c|}{$\begin{array}{l}\text { Table } 7 \\
\text { Ship Speeds Relative to Ground }\end{array}$} \\
\hline \multirow[b]{2}{*}{ Ship Name } & \multirow[b]{2}{*}{\begin{tabular}{|l} 
Date \\
$(2002)$
\end{tabular}} & \multirow[b]{2}{*}{ Direction } & \multicolumn{2}{|c|}{\begin{tabular}{|l|} 
South Site \\
\end{tabular}} & \multicolumn{2}{|c|}{\begin{tabular}{|l|} 
North Site \\
\end{tabular}} \\
\hline & & & \begin{tabular}{|l|} 
Speed from \\
346 to 347 \\
Knots \\
(ft/sec) \\
\end{tabular} & \begin{tabular}{|l|} 
Bow-Stern \\
Timing, \\
knots (ft/sec) \\
\end{tabular} & \begin{tabular}{|l|} 
Speed From \\
349 to 350 \\
Knots \\
$(\mathrm{ft} / \mathrm{sec})$
\end{tabular} & \begin{tabular}{|l} 
Bow-Stern \\
Timing, \\
Knots \\
(ft/sec) \\
\end{tabular} \\
\hline Eagle Augus & 29-Apr & Out & NA & 10.0(16.8) & NA & NA \\
\hline Mount Lady & 29-Apr & Out & NA & $8.4(14.1)$ & NA & NA \\
\hline Noblesse & 29-Apr & In & NA & $9.1(15.3)$ & NA & NA \\
\hline Dafnis & 29-Apr & Out & NA & $13.0(21.9)$ & NA & NA \\
\hline Nordlight & 30-Apr & Out & $10.3(17.3)$ & NA & NA & NA \\
\hline Frankopan & 30-Apr & Out & $9.8(16.5)$ & NA & NA & NA \\
\hline Minerva Joanna & 30-Apr & Out & $9.9(16.7)$ & NA & NA & NA \\
\hline Star America & 30-Apr & $\ln$ & $10.1(17.0)$ & NA & $11.5(19.4)$ & $11.4(19.2)$ \\
\hline Zeebruggee & 30-Apr & $\ln$ & $9.9(16.7)$ & NA & $8.2(13.9)$ & $11.9(20.1)$ \\
\hline Bornes & 30-Apr & $\ln$ & $8.1(13.7)$ & NA & NA & NA \\
\hline $\begin{array}{l}\text { Bernhard } \\
\text { Oldendorf }\end{array}$ & 30-Apr & $\ln$ & $9.8(16.5)$ & NA & $10.0(16.9)$ & NA \\
\hline Kite Arrow & 30-Apr & Out & $11.7(19.8)$ & NA & NA & NA \\
\hline Sunor & 30-Apr & Out & $9.8(16.6)$ & NA & $8.5(14.3)$ & NA \\
\hline Anette & 30-Apr & In & $8.8(14.9)$ & NA & $10.9(18.4)$ & NA \\
\hline Noblesse & 1-May & Out & $11.5(19.4)$ & NA & NA & NA \\
\hline Olga Topic & 1-May & Out & $10.0(16.9)$ & NA & NA & NA \\
\hline Saraband & 1-May & In & $11.2(18.9)$ & $12.3(20.7)$ & $12.3(20.8)$ & $12.7(21.4)$ \\
\hline Zrinski & 1-May & In & $8.4(14.2)$ & $7.6(12.9)$ & $9.0(15.2)$ & NA \\
\hline Astro Antares & 1-May & $\ln$ & $9.0(15.2)$ & $9.0(15.2)$ & $7.5(12.6)$ & $8.8(14.8)$ \\
\hline & & & & & & (Continued) \\
\hline
\end{tabular}




\begin{tabular}{|c|c|c|c|c|c|c|}
\hline \multicolumn{7}{|c|}{ Table 7 (Concluded) } \\
\hline \multirow[b]{2}{*}{ Ship Name } & \multirow[b]{2}{*}{\begin{tabular}{|l} 
Date \\
$(2002)$
\end{tabular}} & \multirow[b]{2}{*}{ Direction } & \multicolumn{2}{|c|}{ South Site } & \multicolumn{2}{|c|}{ North Site } \\
\hline & & & $\begin{array}{l}\text { Speed from } \\
346 \text { to } 347 \\
\text { Knots } \\
\text { (ft/sec) }\end{array}$ & \begin{tabular}{|l|} 
Bow-Stern \\
Timing, \\
Knots \\
(ft/sec) \\
\end{tabular} & $\begin{array}{l}\text { Speed from } \\
349 \text { to } 350 \\
\text { Knots } \\
\text { (ft/sec) }\end{array}$ & \begin{tabular}{|l|} 
Bow-Stern \\
Timing, \\
Knots \\
(ft/sec) \\
\end{tabular} \\
\hline Pacific Sapphire & 1-May & $\ln$ & $8.6(14.5)$ & $8.6(14.5)$ & $7.5(12.7)$ & $8.3(14.0)$ \\
\hline Project Europa & 1-May & $\ln$ & $11.4(19.2)$ & $12.3(20.7)$ & NA & NA \\
\hline S/R Charleston & 1-May & $\ln$ & $9.2(15.6)$ & NA & $9.3(15.7)$ & NA \\
\hline Milagro & 2-May & Out & $11.0(18.6)$ & NA & $10.1(17.1)$ & NA \\
\hline Bornes & 2-May & Out & $10.3(17.3)$ & $9.9(16.7)$ & $9.5(16.1)$ & NA \\
\hline Jo Lonn & 2-May & $\ln$ & $10.3(17.3)$ & $11.0(18.5)$ & $11.5(19.4)$ & $11.0(18.5)$ \\
\hline Eagle Carina & 2-May & $\ln$ & $8.2(13.8)$ & $8.4(14.2)$ & $8.2(13.8)$ & $8.3(14.0)$ \\
\hline Bunga Kelana Dua & 2-May & $\ln$ & $8.0(13.6)$ & NA & NA & $5.6(9.5)$ \\
\hline Grand Orchid & 2-May & $\ln$ & $8.8(14.9)$ & NA & NA & NA \\
\hline Olga Topic & 2-May & Out & $10.0(16.9)$ & NA & NA & NA \\
\hline $\begin{array}{l}\text { Bernhard } \\
\text { Oldendorf }\end{array}$ & 2-May & Out & $9.8(16.6)$ & NA & $8.5(14.4)$ & NA \\
\hline Zeebruggee & 2-May & Out & $13.4(22.6)$ & NA & NA & NA \\
\hline Anette & 3-May & Out & $11.0(18.6)$ & NA & NA & NA \\
\hline Astro Antares & 3-May & Out & $9.2(15.6)$ & NA & $9.3(15.7)$ & NA \\
\hline Genmar Alexandra & 3-May & $\ln$ & $8.0(13.5)$ & NA & $8.5(14.4)$ & NA \\
\hline Eagle Subaru & 3-May & $\ln$ & $7.3(12.3)$ & NA & NA & NA \\
\hline Aldebaran & 3-May & $\ln$ & $8.8(14.9)$ & NA & NA & NA \\
\hline Eagle Auriga & 3-May & $\ln$ & $7.5(12.7)$ & NA & $6.4(10.8)$ & NA \\
\hline Shetland & 3-May & $\ln$ & $11.9(20.0)$ & NA & $11.8(19.9)$ & NA \\
\hline Jo Lonn & 3-May & Out & $9.8(16.5)$ & NA & $9.4(15.9)$ & NA \\
\hline Stolt Tarus & 3-May & Out & $13.3(22.4)$ & NA & NA & NA \\
\hline Pacific Sapphire & 4-May & Out & $10.6(17.8)$ & NA & NA & NA \\
\hline
\end{tabular}




\begin{tabular}{|c|c|c|c|}
\hline \multicolumn{4}{|c|}{$\begin{array}{l}\text { Table } 8 \\
\text { Summary of Speeds Used in Ship Comparison }\end{array}$} \\
\hline \multirow[b]{2}{*}{ Channel } & \multirow[b]{2}{*}{ Ship } & \multicolumn{2}{|c|}{ Speed Used in HIVEL2D Model, Knots (\%Vlimit) } \\
\hline & & South & North \\
\hline$\overline{\text { Existing }}$ & \multirow{2}{*}{$\begin{array}{l}800 \times 140 \times 29 \\
\text { " }\end{array}$} & 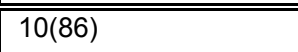 & 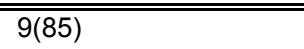 \\
\hline \multirow{3}{*}{$700 \times 50$} & & $11.5(80)$ and $12.2(85)$ & NA \\
\hline & $899 \times 164 \times 30$ & 10.8(80) and 11.5(85) & NA \\
\hline & $899 \times 164 \times 48$ & $8.3(75)$ and $8.9(80)$ & NA \\
\hline Existing $^{1}$ & $899 \times 164 \times 38$ & $\mathrm{NA}^{2}$ & $6.2(73)$ from simulator \\
\hline $400 \times 50^{1}$ & $899 \times 164 \times 48$ & NA & $6.3(75) “$ \\
\hline $500 \times 50^{1}$ & $899 \times 164 \times 48$ & NA & $6.9(75) “$ \\
\hline \multirow{3}{*}{$400 \times 50$} & $800 \times 140 \times 29$ & NA & $9.6(80)$ and $10.2(85)$ \\
\hline & $899 \times 164 \times 30$ & NA & $8.9(80)$ and $9.4(85)$ \\
\hline & $899 \times 164 \times 48$ & NA & $6.3(75)$ and $6.8(80)$ \\
\hline \multicolumn{4}{|c|}{$\begin{array}{l}\text { Not one of the HIVEL2D simulations but the data is provided to show the percent of limit speed } \\
\text { used in the simulator study. } \\
2 \mathrm{NA}=\text { Not applicable. }\end{array}$} \\
\hline
\end{tabular}

\begin{tabular}{|c|c|c|c|c|c|c|c|c|}
\hline \multicolumn{9}{|c|}{$\begin{array}{l}\text { Table } 9 \\
\text { Comparison of Drawdown, Surge, and Transverse Stern Wave, } \\
\text { Scenario } 1\end{array}$} \\
\hline \multirow[b]{2}{*}{ Channel } & \multirow[b]{2}{*}{ Ship } & \multirow{2}{*}{$\begin{array}{l}\text { Speed, } \\
\text { knots South/ } \\
\text { North } \\
\text { (\% limit) } \\
\end{array}$} & \multicolumn{2}{|c|}{ Drawdown, $\mathrm{ft}$} & \multicolumn{2}{|c|}{ Surge, $\mathrm{ft}$} & \multicolumn{2}{|c|}{$\begin{array}{c}\text { Transverse } \\
\text { Stern Wave, } \mathrm{ft}\end{array}$} \\
\hline & & & South & North & South & North & South & North \\
\hline Existing & Design & $10 / 9(85)$ & 3.6 & 2.9 & 1.8 & 1.4 & 5.4 & 4.3 \\
\hline \multirow[t]{2}{*}{ Proposed } & & \begin{tabular}{|l|}
$11.5 / 9.6(80)$ \\
\end{tabular} & 3.55 & 3.0 & 2.3 & 1.7 & 5.8 & 4.7 \\
\hline & & \begin{tabular}{|l|}
$12.2 / 10.2(85)$ \\
\end{tabular} & 4.55 & 3.2 & 2.9 & 1.9 & 7.5 & \begin{tabular}{|l|}
5.1 \\
\end{tabular} \\
\hline
\end{tabular}

\begin{tabular}{|l}
\hline \begin{tabular}{l}
\hline Table 10 \\
Comparison of Drawdown, Surge, and Transverse Stern Wave, \\
Scenario 2
\end{tabular} \\
\hline \hline \multirow{3}{*}{ Channel }
\end{tabular}




\begin{tabular}{|c|c|c|c|c|c|c|c|c|}
\hline \multicolumn{9}{|c|}{$\begin{array}{l}\text { Table } 11 \\
\text { Drawdown, Surge, and Transverse Stern Wave for } 90 \text { Percent of } \\
\text { Limit Speed }\end{array}$} \\
\hline \multirow[b]{2}{*}{ Channel } & \multirow[b]{2}{*}{ Ship } & \multirow{2}{*}{$\begin{array}{l}\text { Speed, knots } \\
\text { South/ North } \\
\text { (\%limit) }\end{array}$} & \multicolumn{2}{|c|}{ Drawdown, $\mathrm{ft}$} & \multicolumn{2}{|c|}{ Surge, $\mathrm{ft}$} & \multicolumn{2}{|c|}{\begin{tabular}{|c|c|} 
Transverse \\
Stern Wave, $\mathrm{ft}$
\end{tabular}} \\
\hline & & & South & North & South & North & South & North \\
\hline Existing & Design & \begin{tabular}{|l|l}
$10.6 / 9.5(90)$ \\
\end{tabular} & 4.55 & 3.2 & 2.3 & 1.7 & 6.8 & 4.9 \\
\hline Proposed & & $12.9 / 10.8(90)$ & 5.0 & 3.3 & 3.4 & 2.2 & 8.4 & 5.5 \\
\hline
\end{tabular}

\begin{tabular}{|c|c|c|c|c|c|c|}
\hline \multicolumn{7}{|c|}{$\begin{array}{l}\text { Table } 12 \\
\text { Ships Used in Speed Restriction Evaluation }\end{array}$} \\
\hline Channel & Area, sq ft & $\begin{array}{l}\text { Actual and } \\
\text { Modeled } \\
\text { Length } \\
\end{array}$ & $\begin{array}{l}\text { Actual } \\
\text { Beam, ft }\end{array}$ & $\begin{array}{l}\text { Actual } \\
\text { Draft, ft }\end{array}$ & $\begin{array}{l}\text { Modeled } \\
\text { Beam, ft }\end{array}$ & $\begin{array}{l}\text { Modeled } \\
\text { Draft }\end{array}$ \\
\hline$\overline{E \& P^{1}}$ & 1,500 & 500 & 80 & 18.75 & 80 & 18.75 \\
\hline " & 3,500 & 650 & 106 & 33.0 & 120 & 29.17 \\
\hline " & 5,500 & 810 & 140 & 39.3 & 180 & 30.56 \\
\hline P only & 7,872 & 900 & 164 & 48 & 200 & 39.36 \\
\hline
\end{tabular}

\begin{tabular}{|c|c|c|c|c|}
\hline \multicolumn{5}{|c|}{$\begin{array}{l}\text { Table } 13 \\
\text { Results of HIVEL2D and Equation } 5 \text { in Speed Evaluation of Existing } \\
\text { Canal, South Site (Based on HIVEL2D Node 16002) }\end{array}$} \\
\hline Area, sq ft & Speed, knots & $\begin{array}{l}\begin{array}{l}\text { Drawdown, } \mathrm{ft} \\
\text { (HIVEL2D) }\end{array} \\
\end{array}$ & Surge, ft (Eq 5) & $\begin{array}{l}\begin{array}{l}\text { Transverse Stern } \\
\text { Wave, ft }\end{array} \\
\end{array}$ \\
\hline 1,500 & 12.2 & 2.0 & 1.8 & 3.8 \\
\hline 3,500 & 9.8 & 2.8 & 1.5 & 4.3 \\
\hline 5,500 & 8.1 & 2.6 & 1.0 & 3.6 \\
\hline
\end{tabular}

\begin{tabular}{|c|c|c|c|c|}
\hline \multicolumn{5}{|c|}{$\begin{array}{l}\text { Table } 14 \\
\text { Results of HIVEL2D and Equation } 5 \text { in Speed Evaluation of Existing } \\
\text { Canal, North Site (Based on HIVEL2D Node 16952) }\end{array}$} \\
\hline Area, sq ft & Speed, knots & $\begin{array}{l}\begin{array}{l}\text { Drawdown, ft } \\
\text { (HIVEL2D) }\end{array} \\
\end{array}$ & Surge, $\mathrm{ft}$ (Eq 5) & $\begin{array}{l}\text { Transverse Stern } \\
\text { Wave, } \mathrm{ft}\end{array}$ \\
\hline 1,500 & 11.5 & 1.6 & 1.6 & 3.2 \\
\hline 3,500 & 9.0 & 2.4 & 1.3 & 3.7 \\
\hline 5,500 & 7.3 & 2.3 & 0.8 & 3.1 \\
\hline
\end{tabular}




\begin{tabular}{|c|c|c|c|c|}
\hline \multicolumn{5}{|c|}{$\begin{array}{l}\text { Table } 15 \\
\text { Results of HIVEL2D and Equation } 5 \text { in Speed Evaluation of Proposed } \\
\text { Canal, South Site (Based on HIVEL2D Node 16002) }\end{array}$} \\
\hline Area, sq ft & \begin{tabular}{|l|}
$\begin{array}{l}\text { Speed, knots } \\
\text { (\% limit) }\end{array}$ \\
\end{tabular} & \begin{tabular}{|l}
$\begin{array}{l}\text { Drawdown, ft } \\
\text { (HIVEL2D) }\end{array}$ \\
\end{tabular} & Surge, ft (Eq 5) & $\begin{array}{l}\begin{array}{l}\text { Transverse Stern } \\
\text { Wave, } \mathrm{ft}\end{array} \\
\end{array}$ \\
\hline \multirow[t]{4}{*}{1,500} & $14.1(80)$ & 1.9 & 2.3 & 4.2 \\
\hline & $13.2(75)$ & 1.7 & 1.8 & 3.5 \\
\hline & $11.9(67.5)$ & 1.0 & 1.1 & 2.1 \\
\hline & $10.55(60)$ & 0.7 & 0.7 & 1.4 \\
\hline \multirow[t]{4}{*}{3,500} & $11.9(80)$ & 3.2 & 2.3 & 5.5 \\
\hline & $11.2(75)$ & 2.5 & 1.7 & 4.2 \\
\hline & $10.1(67.5)$ & 1.7 & 1.1 & 2.8 \\
\hline & $8.9(60)$ & 1.0 & 0.7 & 1.7 \\
\hline \multirow[t]{3}{*}{5,500} & $9.7(75)$ & 3.0 & 1.5 & 4.5 \\
\hline & $8.7(67.5)$ & 1.9 & 0.9 & 2.8 \\
\hline & $7.8(60)$ & 1.1 & 0.6 & 1.7 \\
\hline \multirow[t]{3}{*}{7,872} & $8.3(75)$ & 2.9 & 1.1 & 4.0 \\
\hline & $7.5(67.5)$ & 1.9 & 0.7 & 2.6 \\
\hline & $6.7(60)$ & 1.2 & 0.5 & 1.7 \\
\hline
\end{tabular}

\begin{tabular}{|c|c|c|c|c|}
\hline \multicolumn{5}{|c|}{$\begin{array}{l}\text { Table } 16 \\
\text { Results of HIVEL2D and Equation } 5 \text { in Speed Evaluation of Proposed } \\
\text { Canal, North Site (Based on HIVEL2D Node 16952) }\end{array}$} \\
\hline Area, sq ft & \begin{tabular}{|l|}
$\begin{array}{l}\text { Speed, knots } \\
\text { (\% limit) }\end{array}$ \\
\end{tabular} & $\begin{array}{l}\begin{array}{l}\text { Drawdown, ft } \\
\text { (HIVEL2D) }\end{array} \\
\end{array}$ & Surge, $\mathrm{ft}(\mathrm{Eq} 5)$ & $\begin{array}{l}\text { Transverse Stern } \\
\text { Wave, ft }\end{array}$ \\
\hline \multirow[t]{3}{*}{1,500} & $11.9(75)$ & 1.5 & 1.6 & 3.1 \\
\hline & $10.7(67.5)$ & 1.0 & 1.1 & 2.1 \\
\hline & $9.5(60)$ & 0.7 & 0.7 & 1.4 \\
\hline \multirow[t]{3}{*}{3,500} & $9.6(75)$ & 2.4 & 1.4 & 3.8 \\
\hline & $8.6(67.5)$ & 1.8 & 1.0 & 2.8 \\
\hline & $7.7(60)$ & 1.2 & 0.6 & 1.8 \\
\hline \multirow[t]{3}{*}{5,500} & $7.9(75)$ & 2.5 & 1.0 & 3.5 \\
\hline & $7.1(67.5)$ & 1.6 & 0.7 & 2.3 \\
\hline & $6.3(60)$ & 1.0 & 0.4 & 1.4 \\
\hline \multirow[t]{4}{*}{7,872} & $6.7(80)$ & & & \\
\hline & $6.3(75)$ & 2.0 & 0.6 & 2.6 \\
\hline & $5.7(67.5)$ & 1.4 & 0.4 & 1.8 \\
\hline & $5.1(60)$ & 1.1 & 0.3 & 1.4 \\
\hline
\end{tabular}




\section{Appendix A Time-Histories of Water Level, Existing Channel}




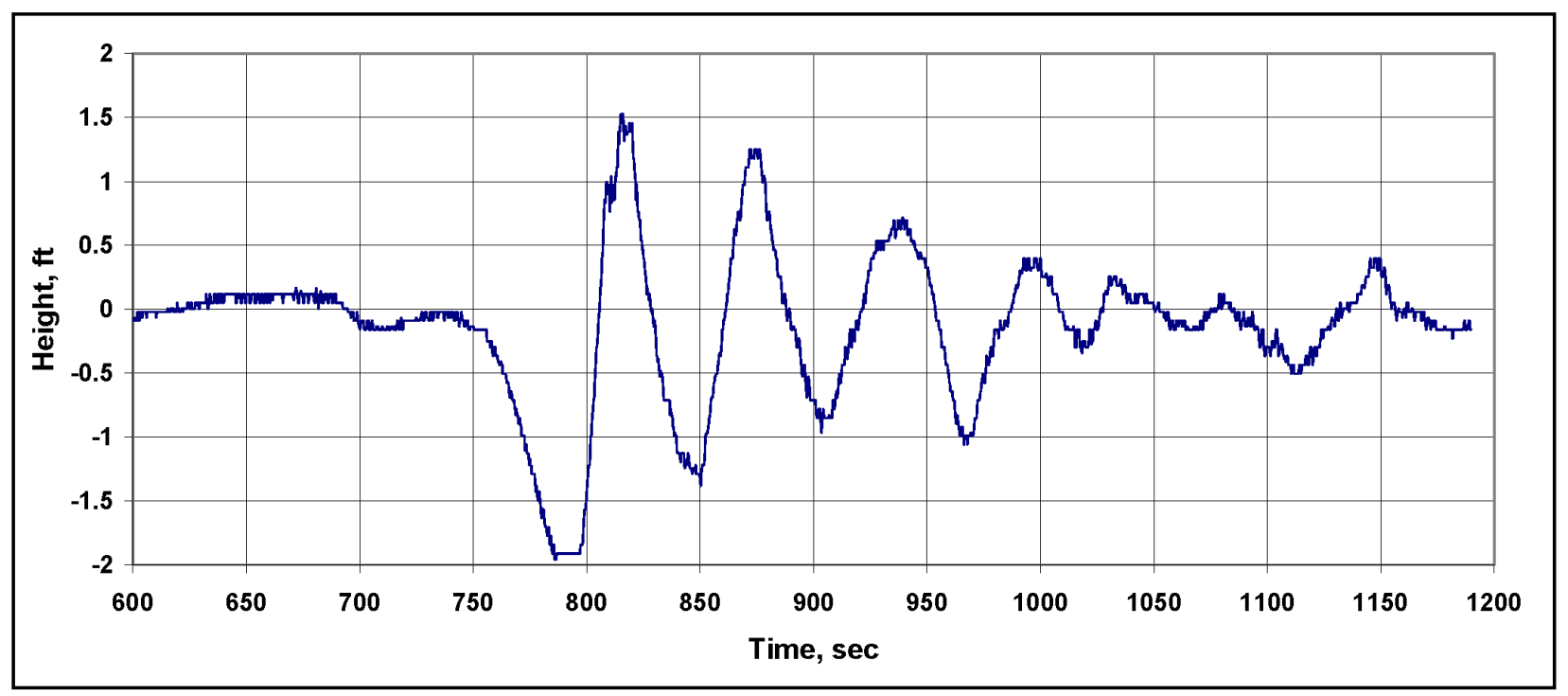

Figure A1. Kite Arrow, south site, outbound, time $0=2120,30$ April 2002, pressure cell 1200346b

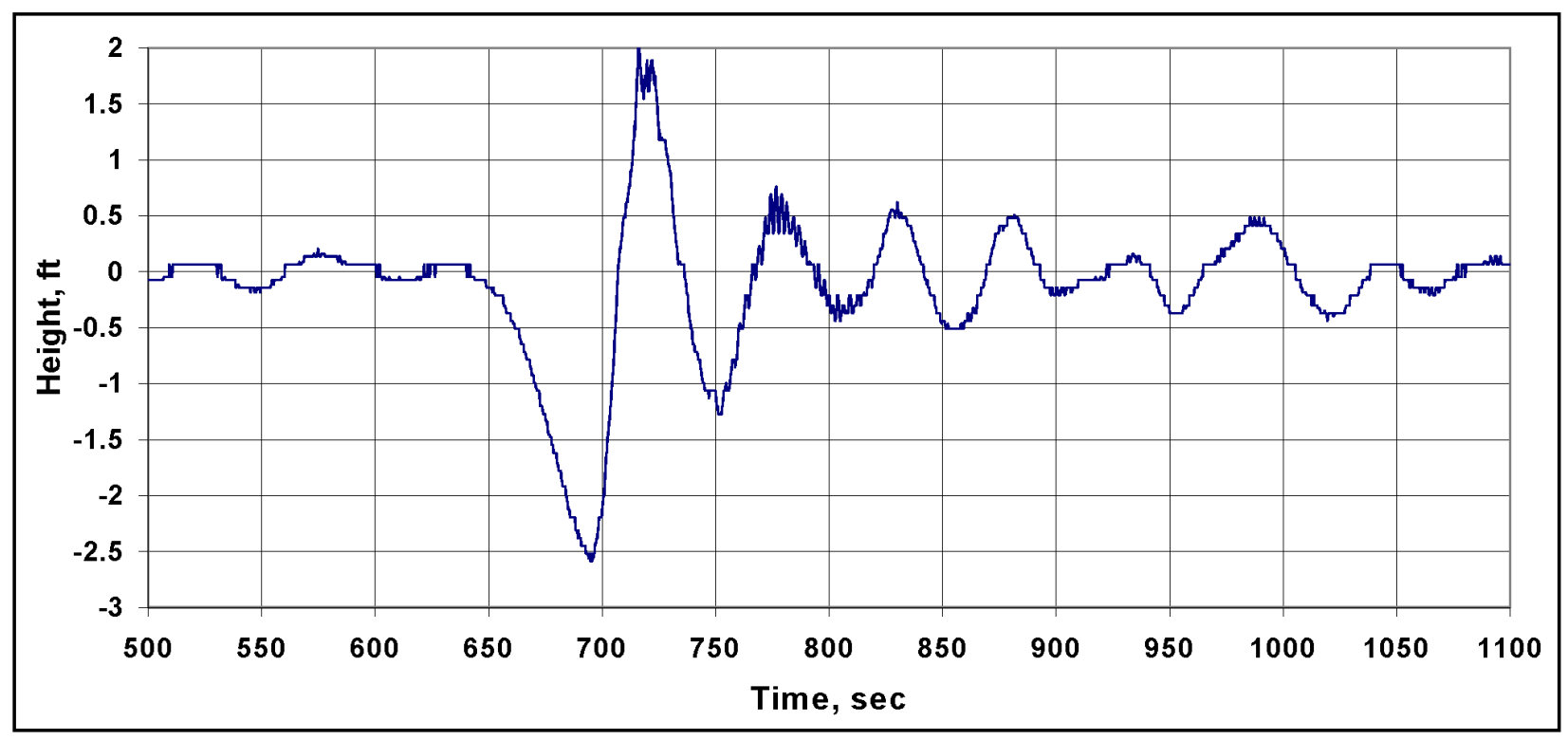

Figure A2. Kite Arrow, south site, outbound, time $0=2120,30$ April 2002, pressure cell 1200347b 


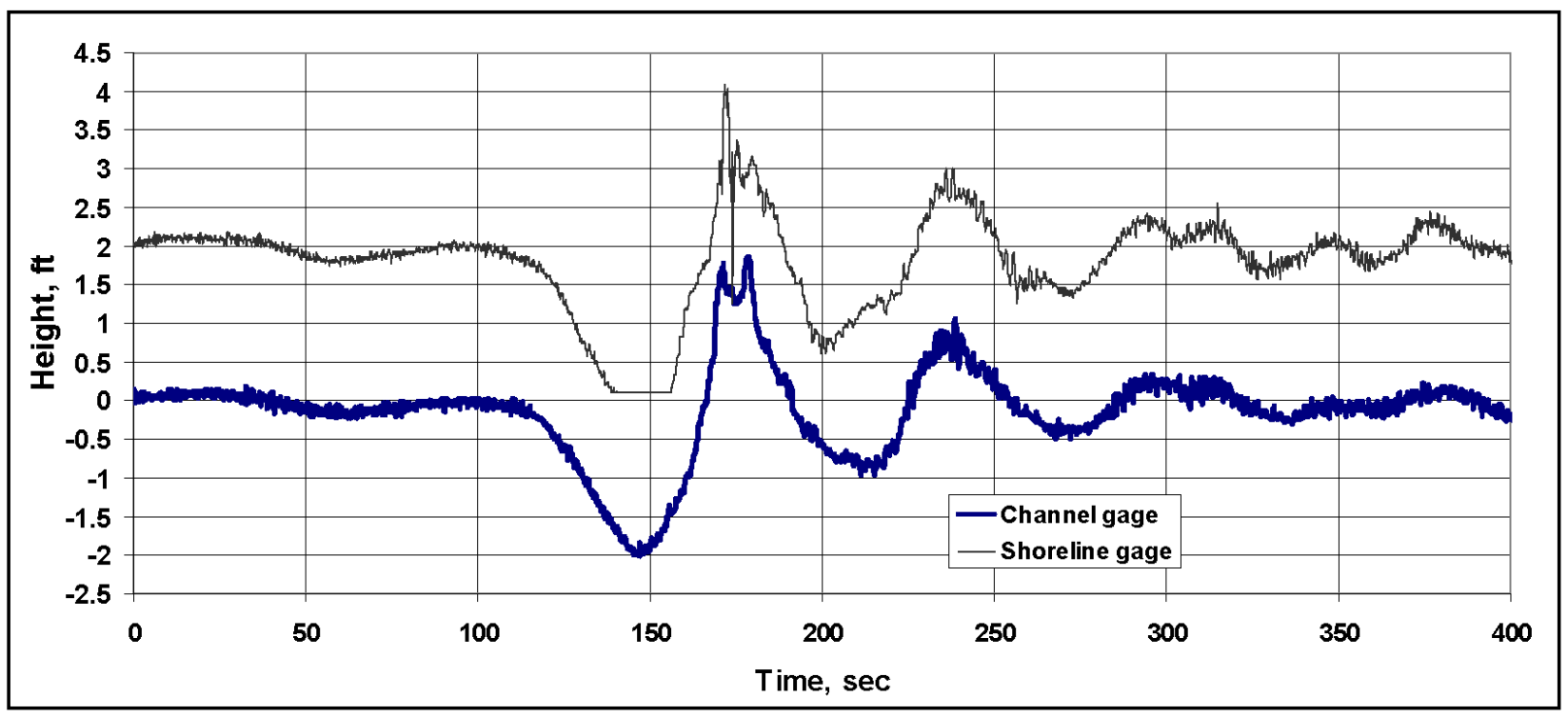

Figure A3. Kite Arrow, south site, outbound, time $0=2130,30$ Apr 2002, capacitance cell 1200522b

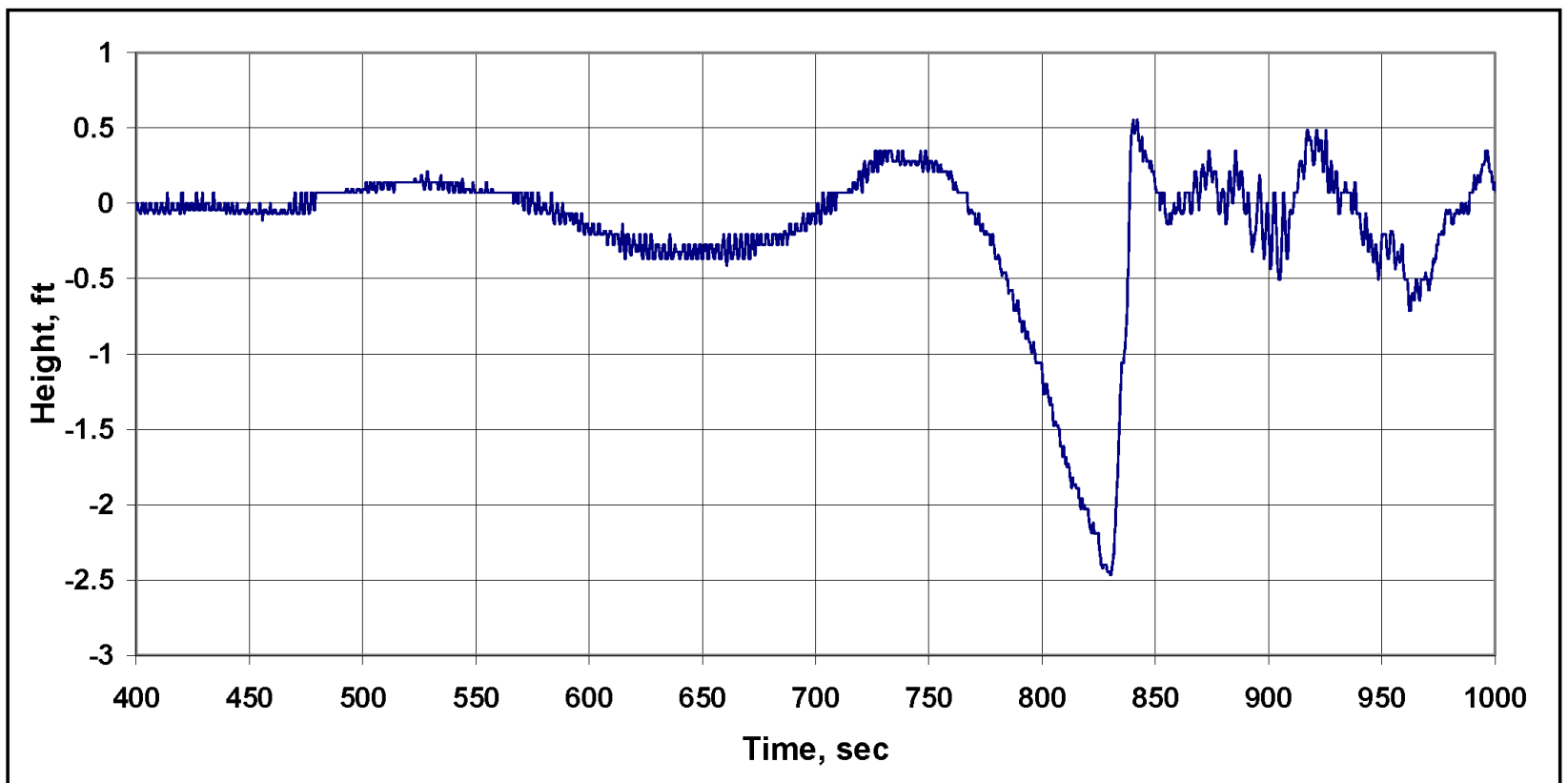

Figure A4. S/R Charleston, south site, inbound, time $0=2120,1$ May 2002, pressure cell $1210346 \mathrm{~b}$ 


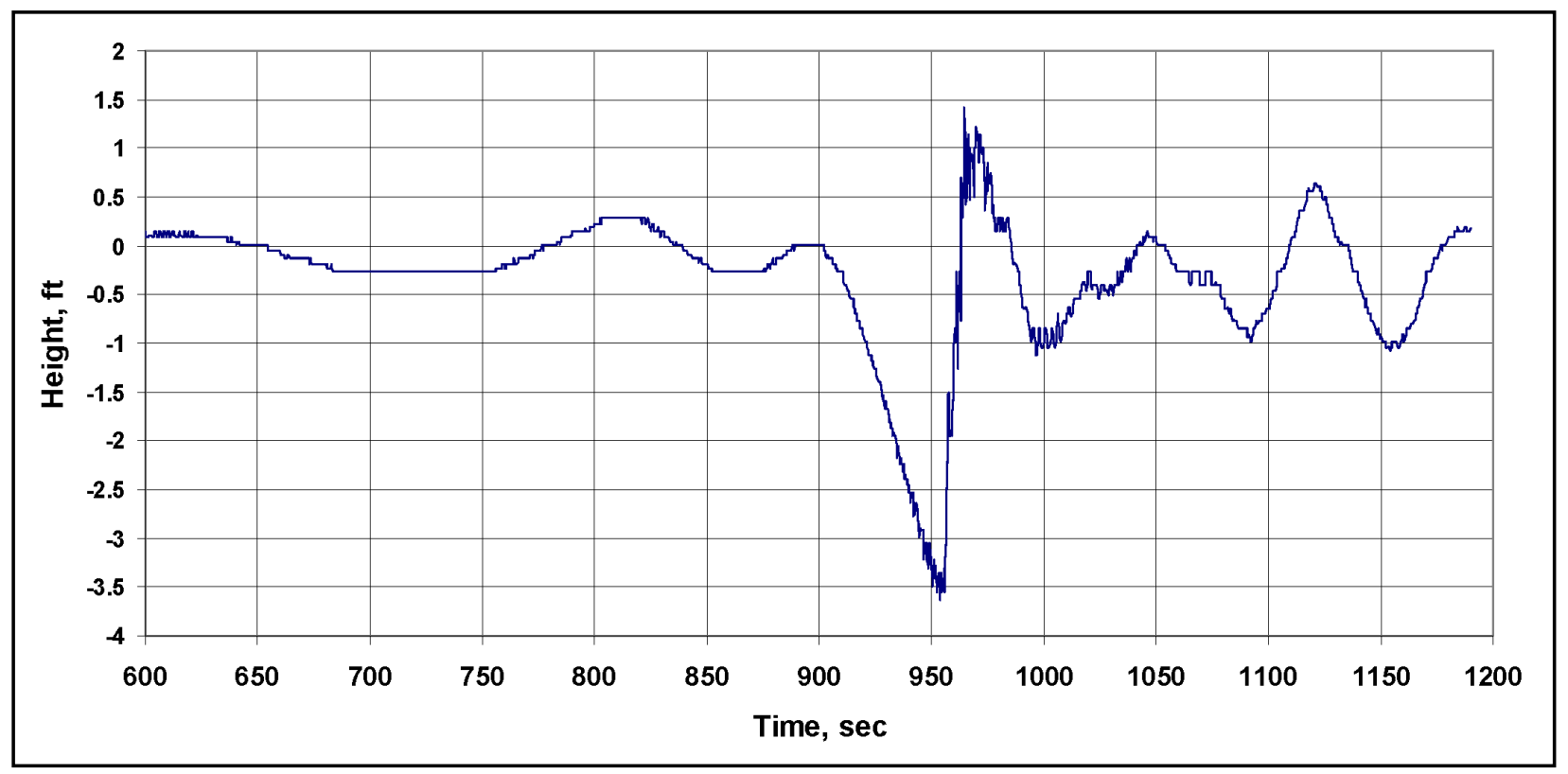

Figure A5. S/R Charleston, south site, inbound, time $0=2120,1$ May 2002, pressure cell $1210347 \mathrm{~b}$

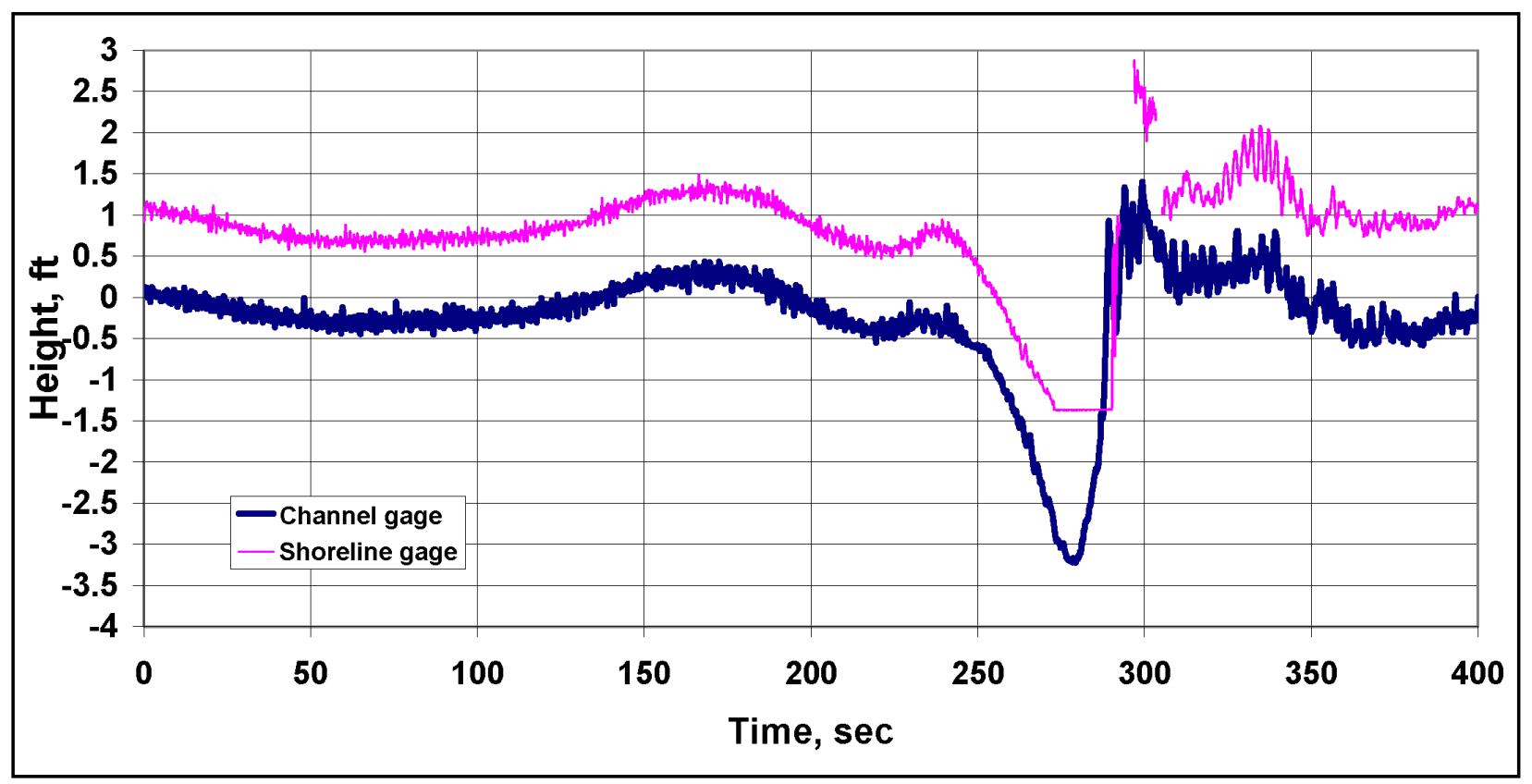

Figure A6. S/R Charleston, south site, inbound, time $0=2130,1$ May 2002, capacitance cell 1210520b 


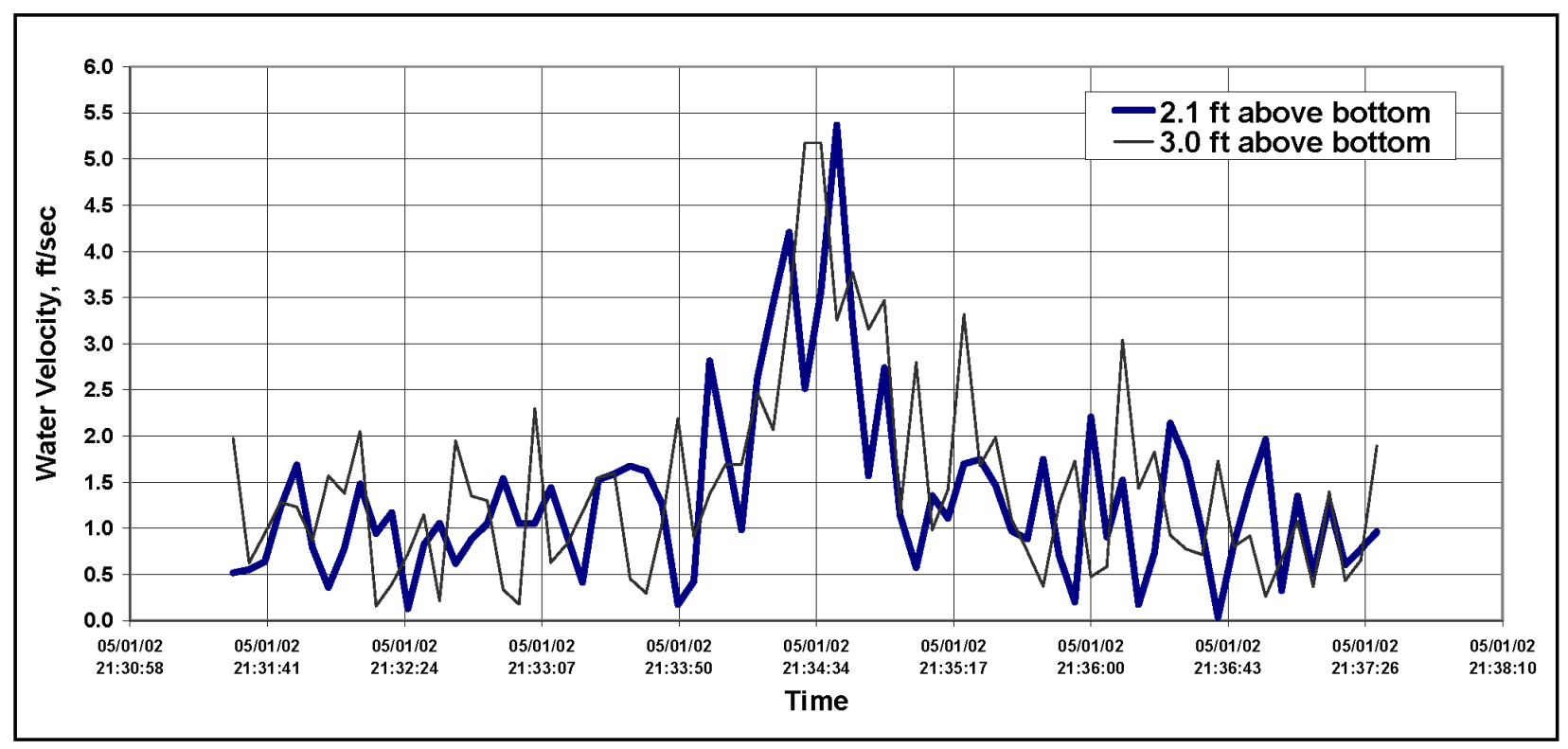

Figure A7. S/R Charleston, south site, inbound, 1 May 2002, water velocity

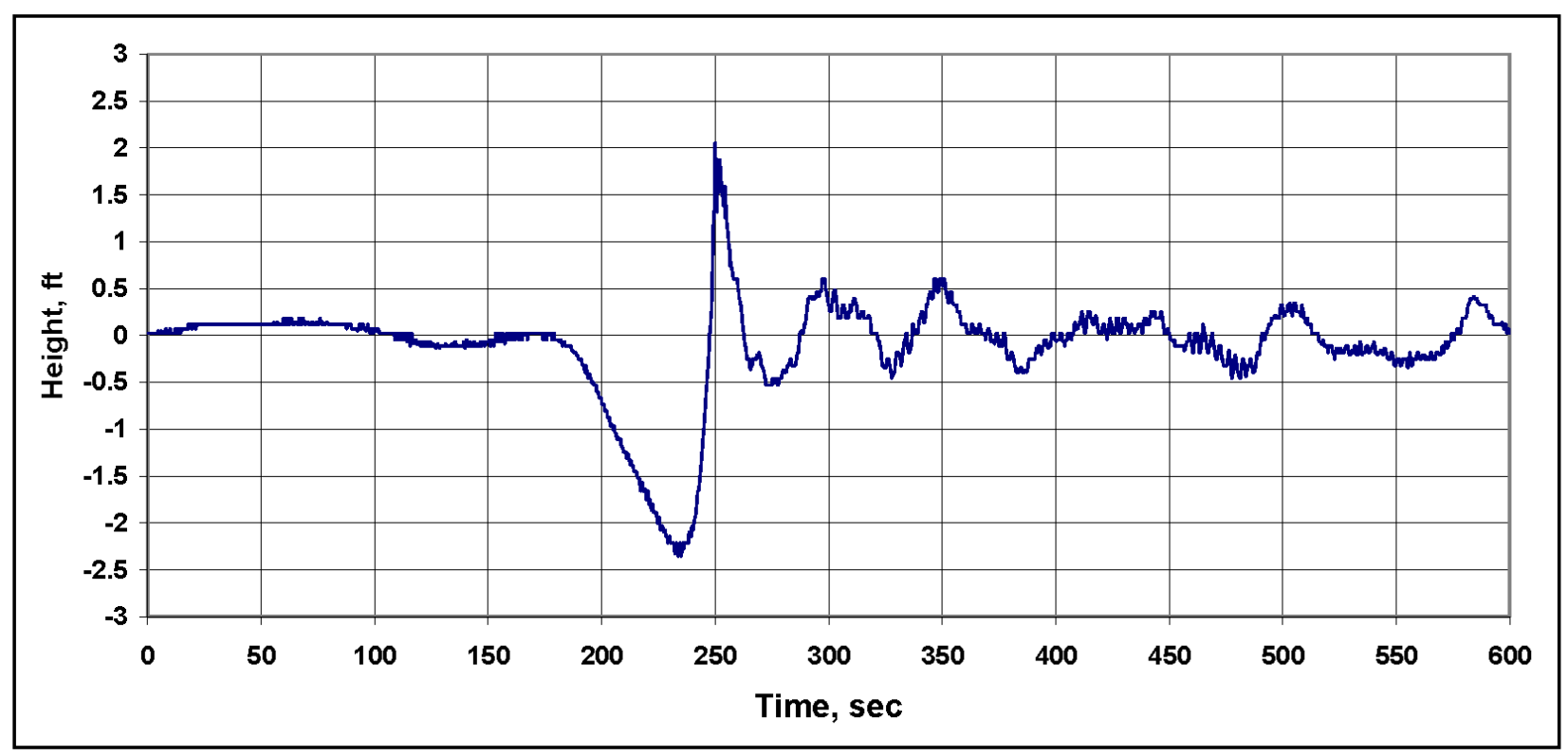

Figure A8. Bornes, south site, outbound, time $0=0800,2$ May 2002, pressure cell 1210346b 


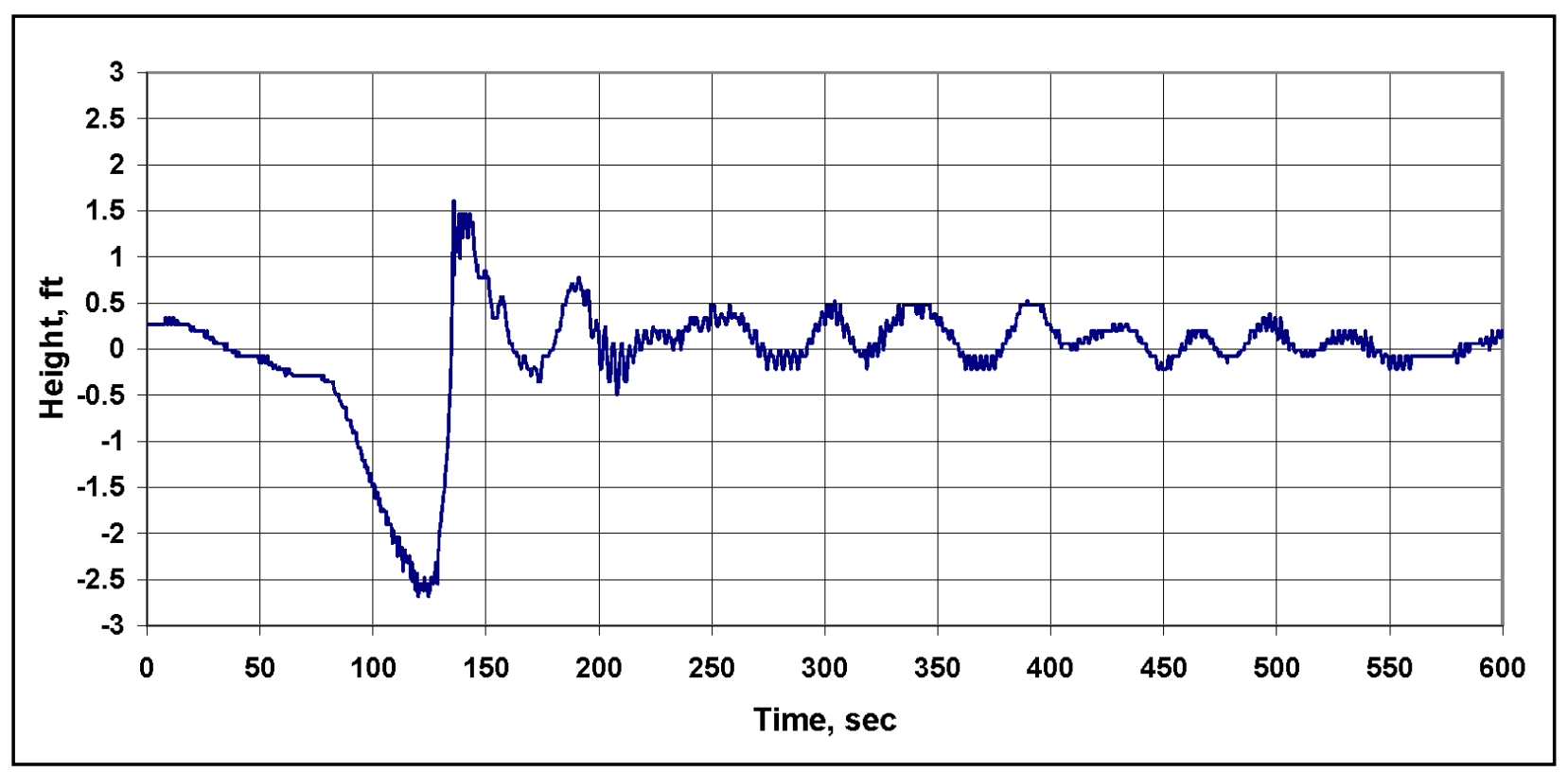

Figure A9. Bornes, south site, outbound, time $0=0800,2$ May 2002, pressure cell 1210347b

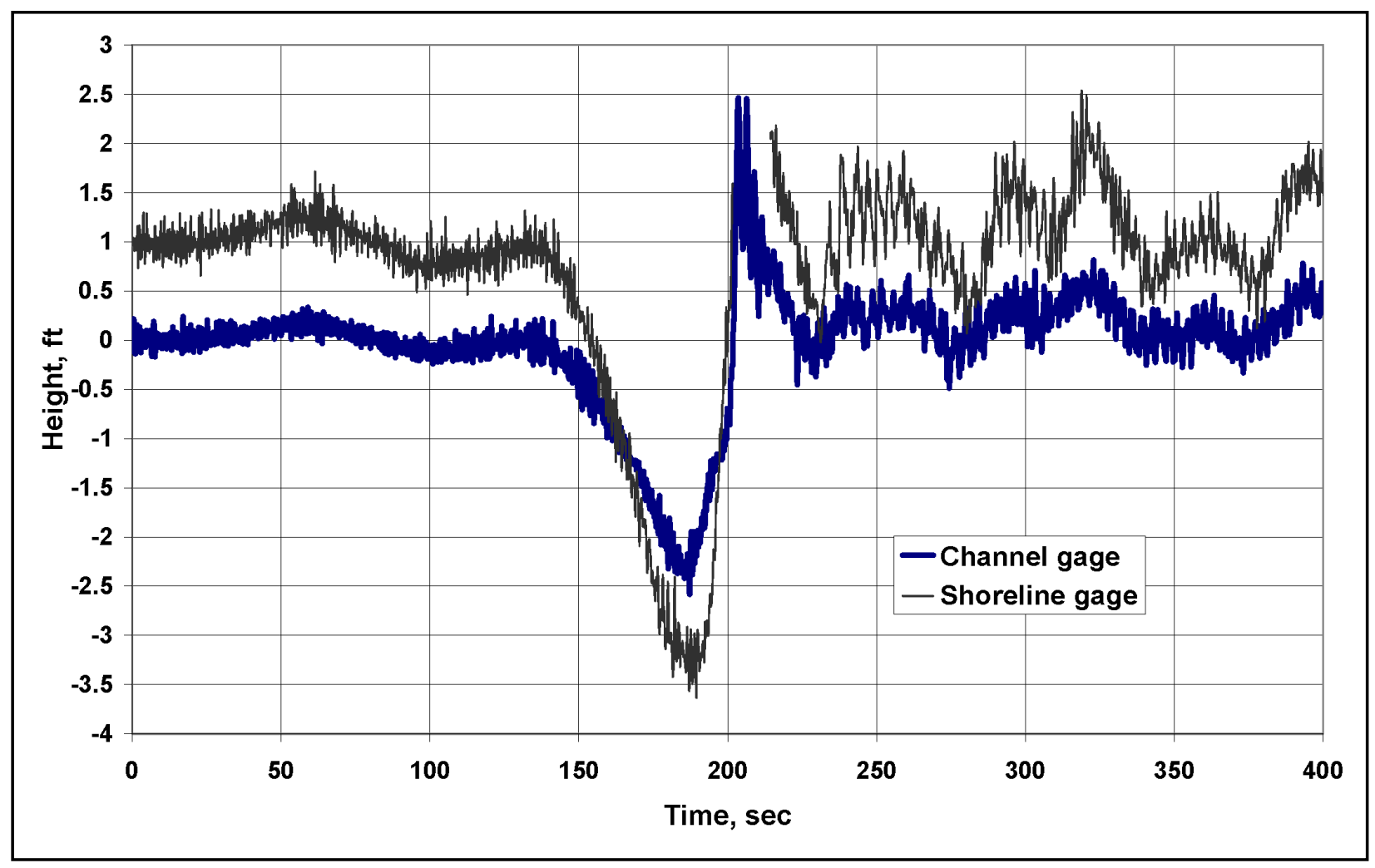

Figure A10. Bornes, south site, outbound, time $0=0800,2$ May 2002, capacitance cell 1210520b 


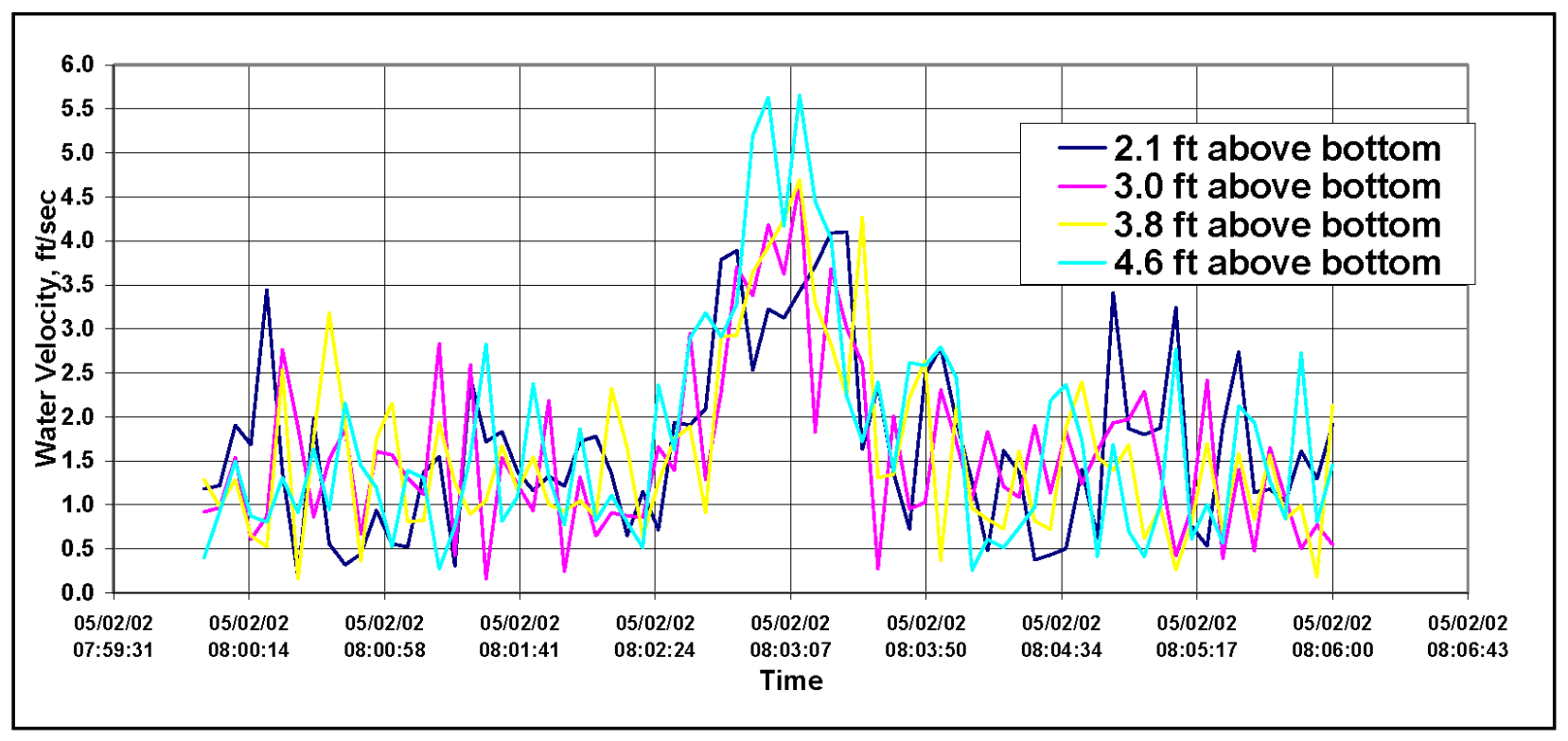

Figure A11. Bornes, south site, outbound, 2 May 2002, water velocity

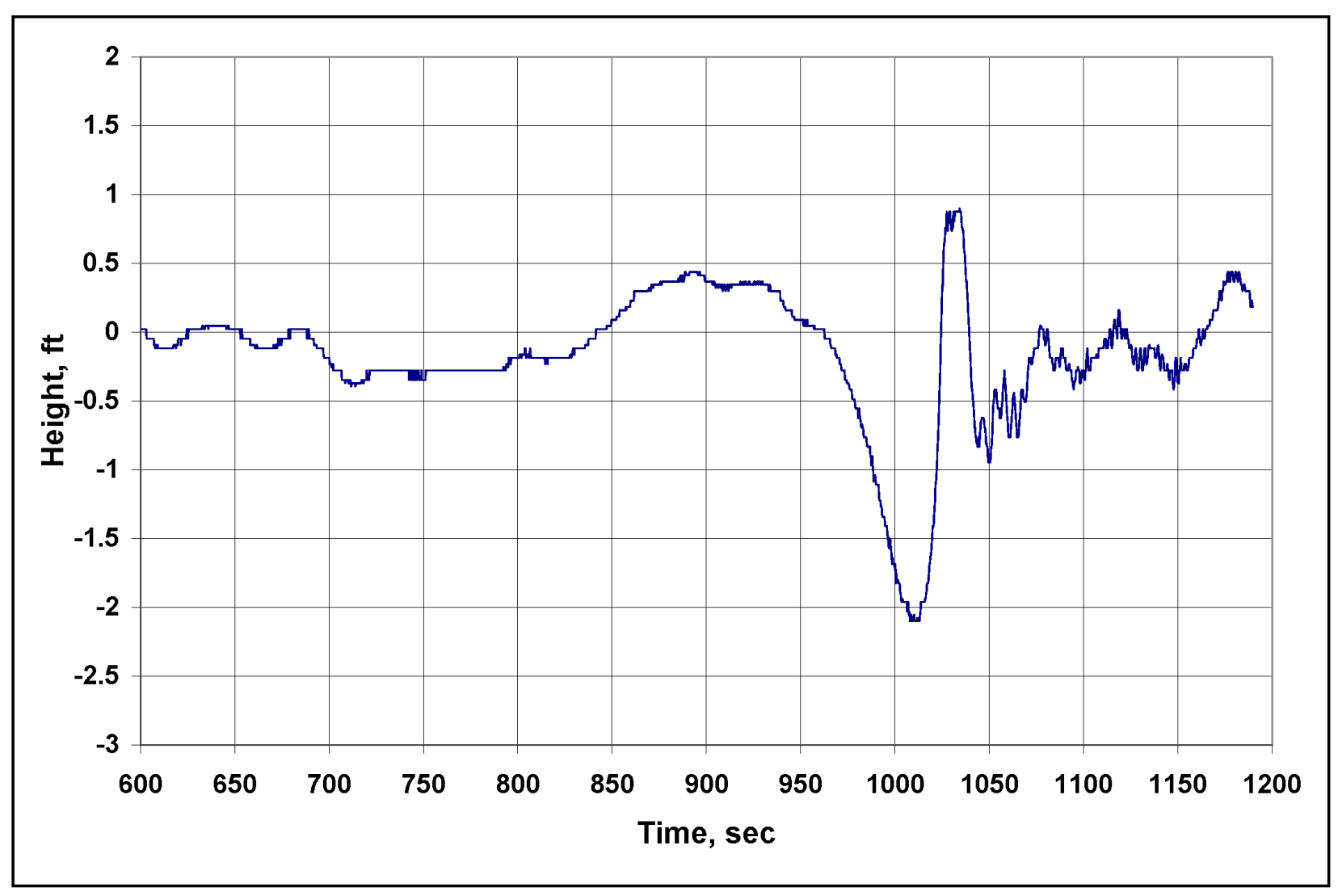

Figure A12. Eagle Carina, south site, inbound, time $0=1200,2$ May 2002, pressure cell 1210346b 


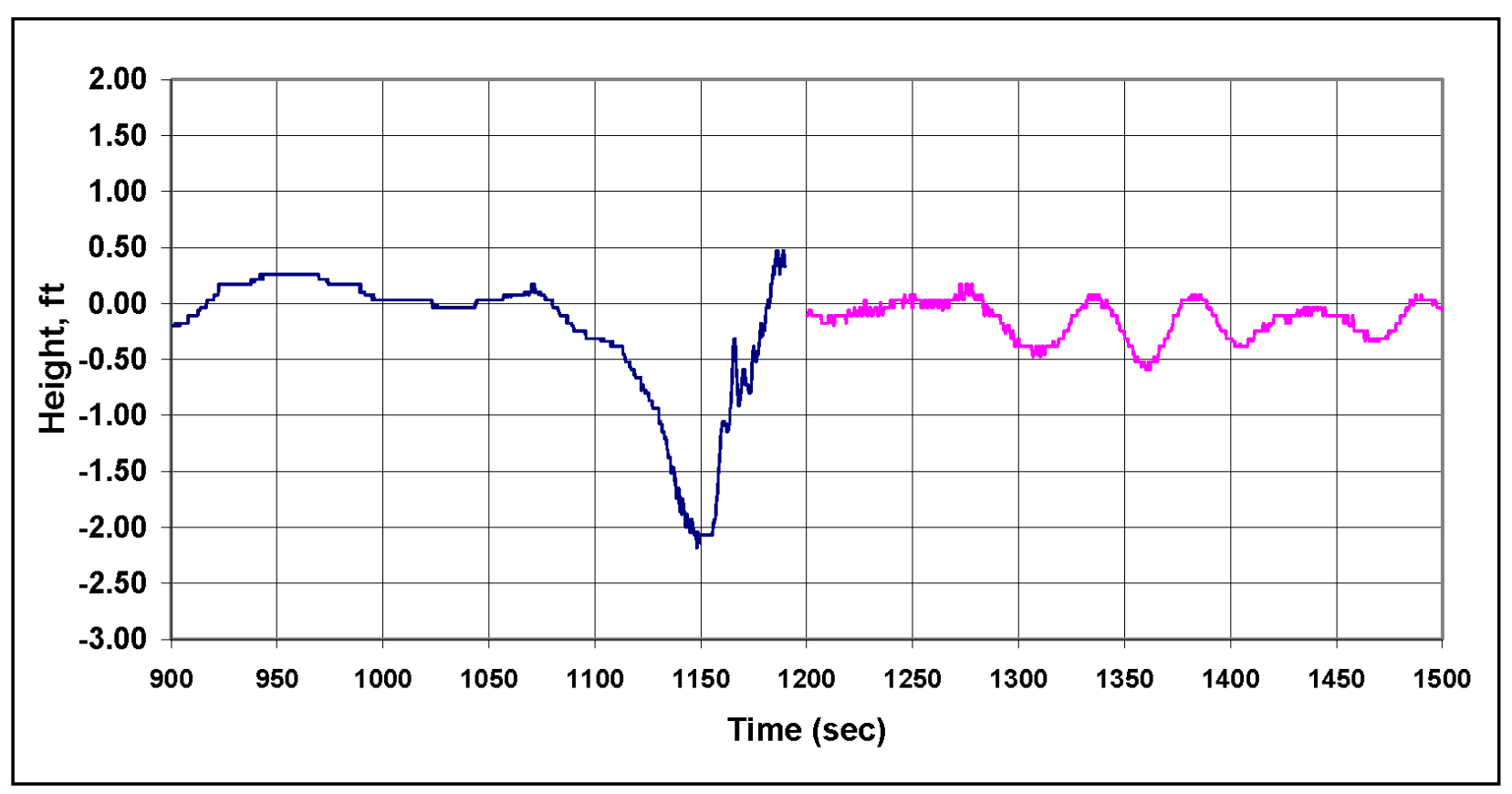

Figure A13. Eagle Carina, south site, inbound, time $0=1200,2$ May 2002, pressure cell 1210347b

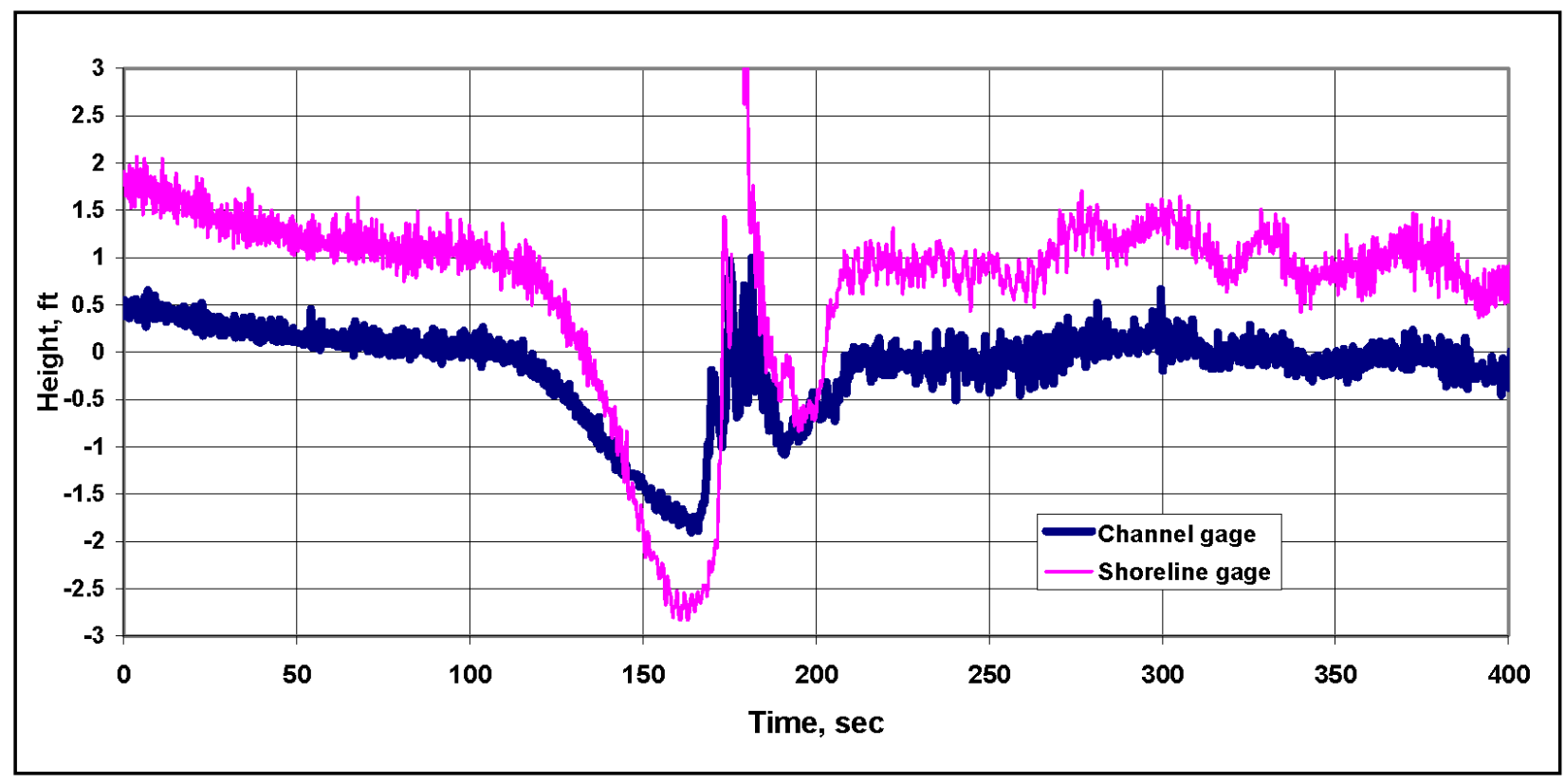

Figure A14. Eagle Carina, south site, inbound, time $0=1215,2$ May 2002, capacitance cell 1210520b 


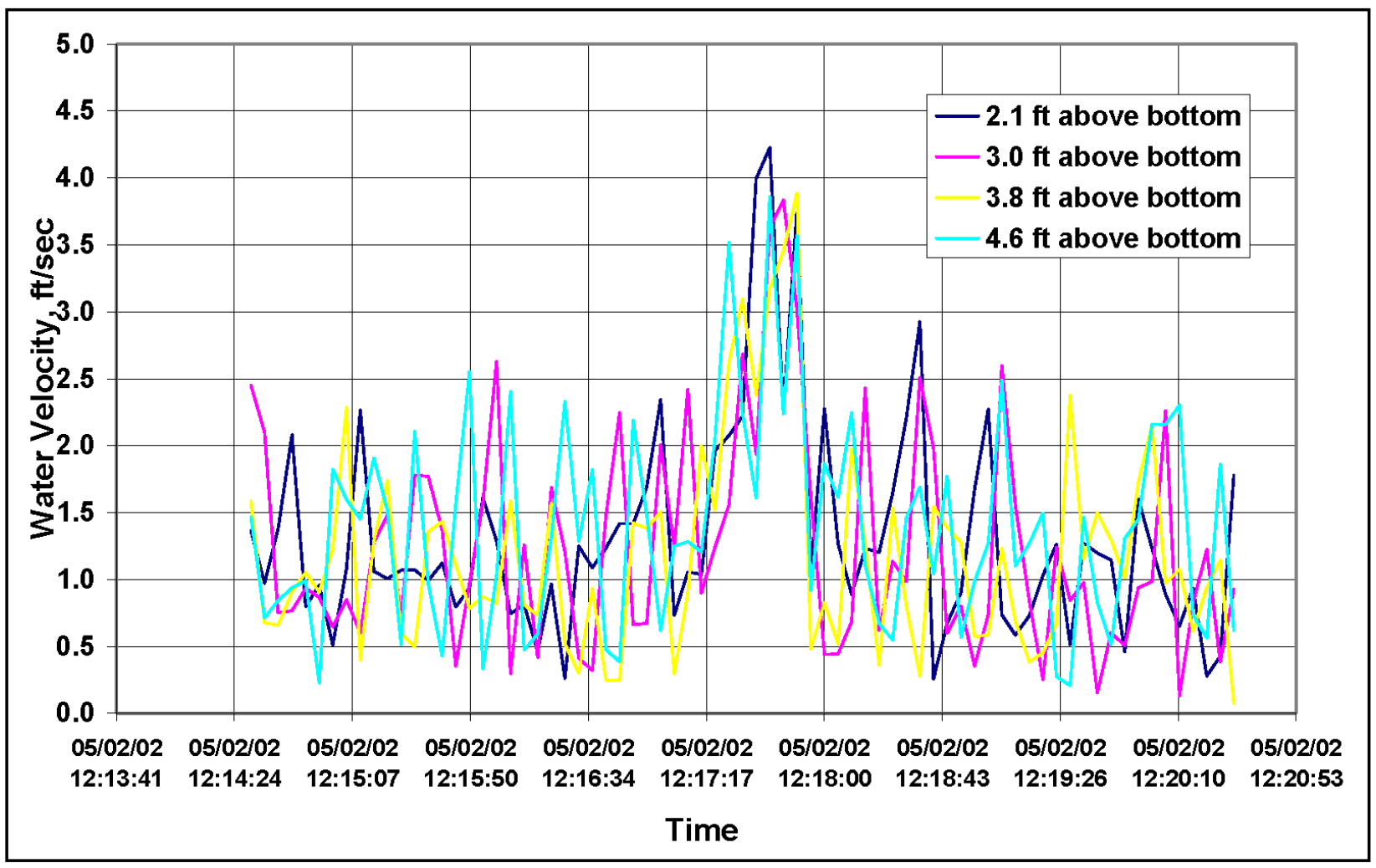

Figure A15. Eagle Carina, south site, inbound, 2 May 2002, water velocity

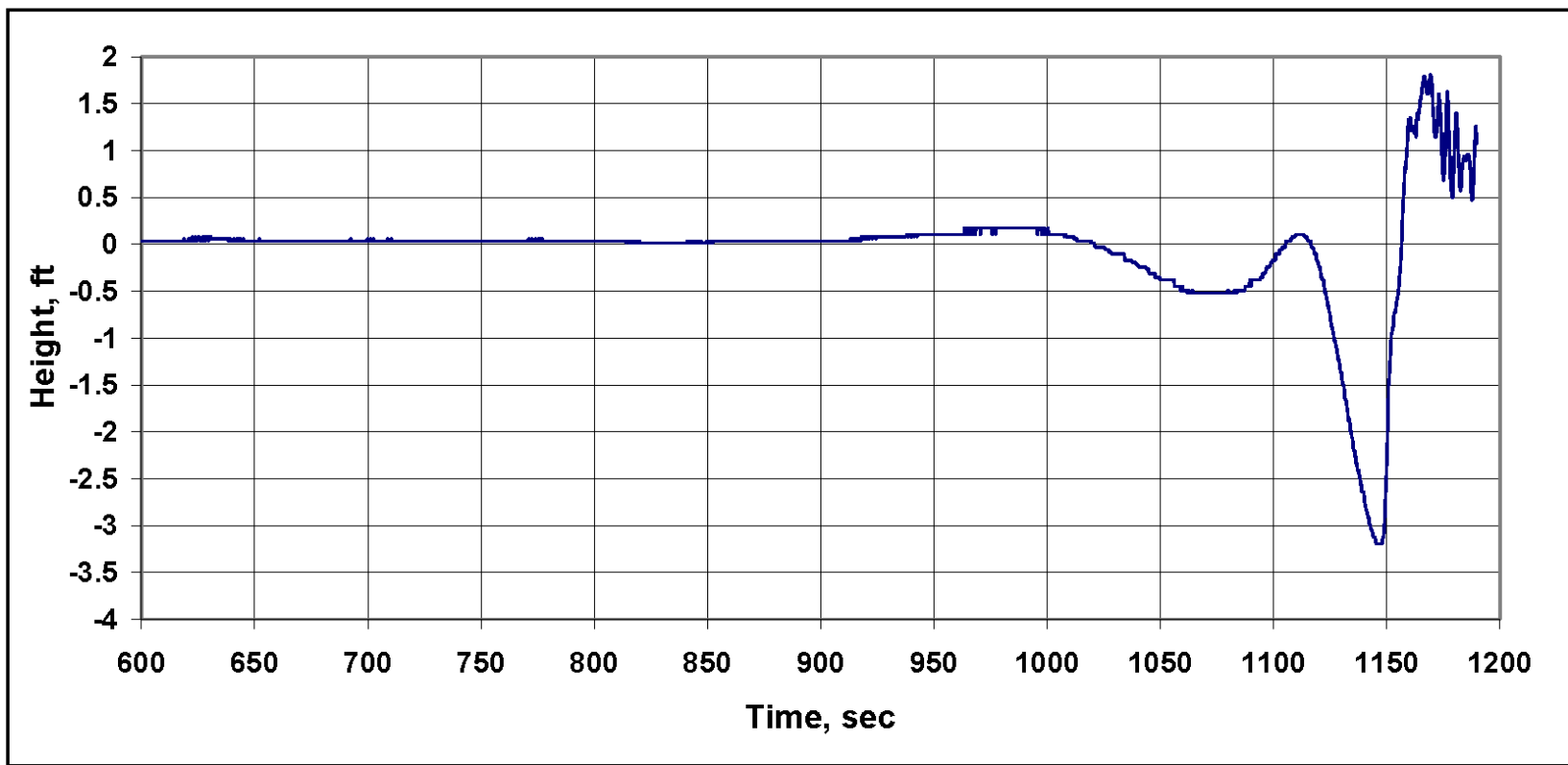

Figure A16. Shetland, south site, inbound, time $0=1920,3$ May 2002, pressure cell $1230346 \mathrm{~b}$ 


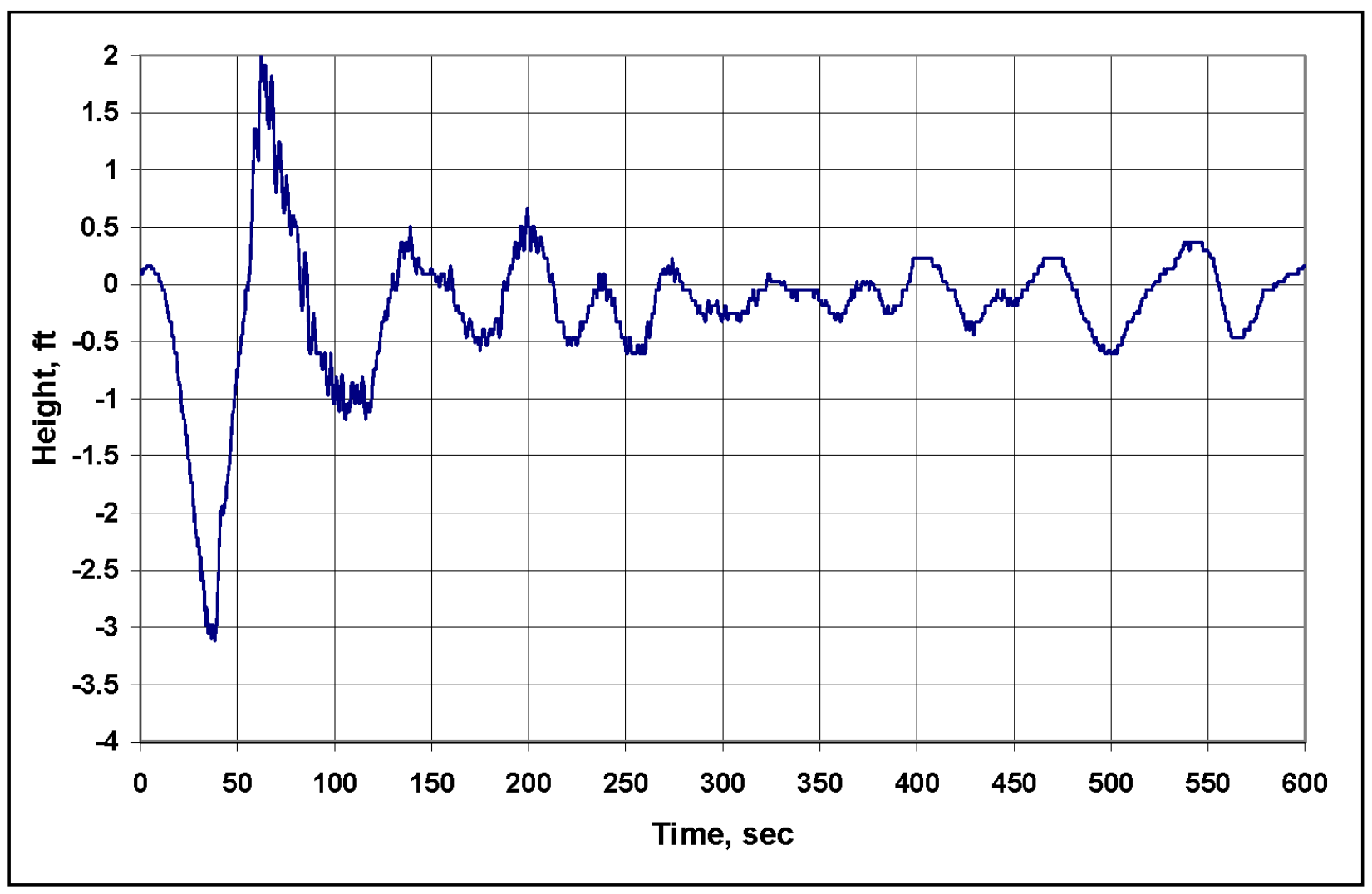

Figure A17. Shetland, south site, inbound, time $0=1940,3$ May 2002, pressure cell $1230347 \mathrm{~b}$ 


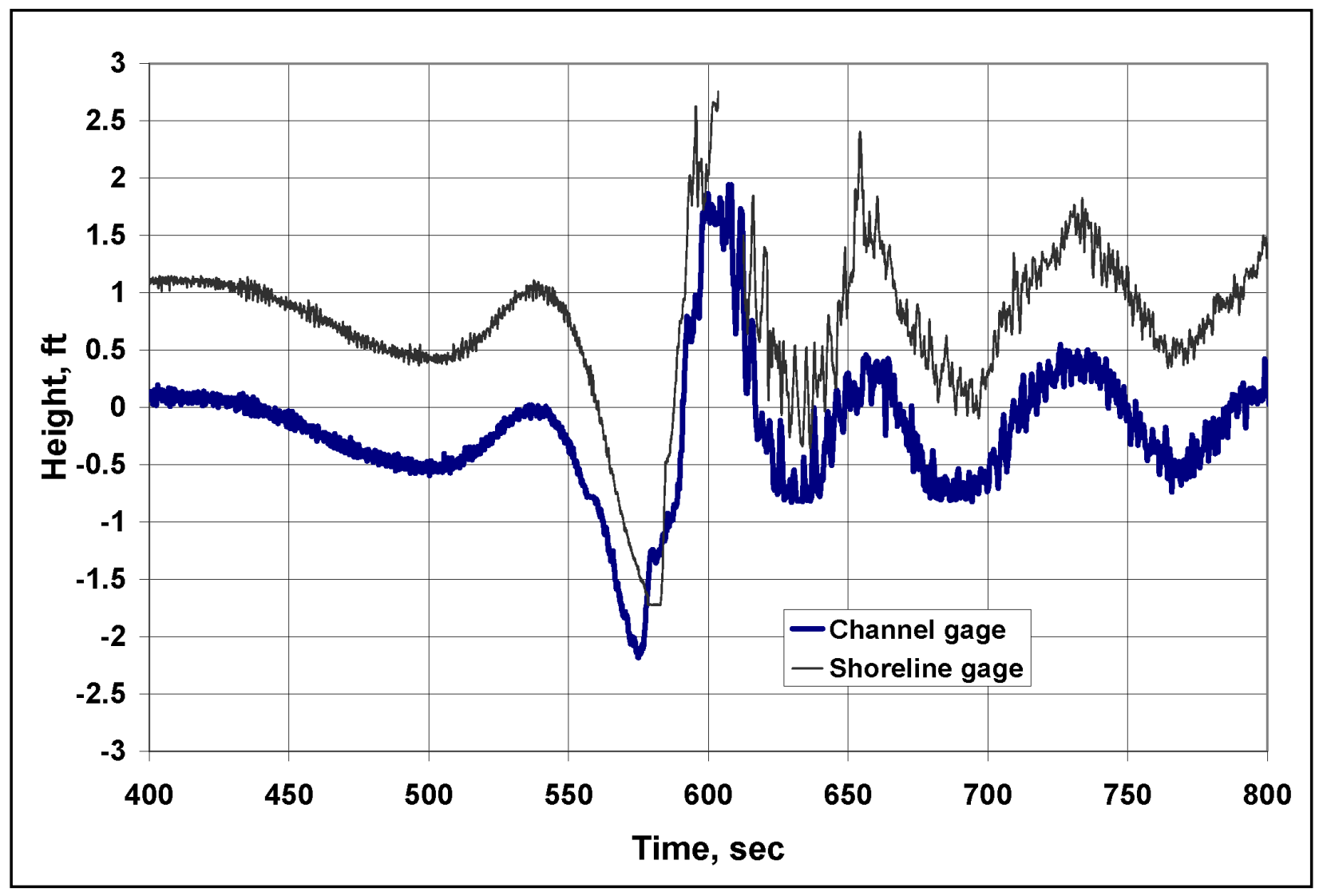

Figure A18. Shetland, south site, inbound, time $0=1930,3$ May 2002, capacitance cell 1220526b

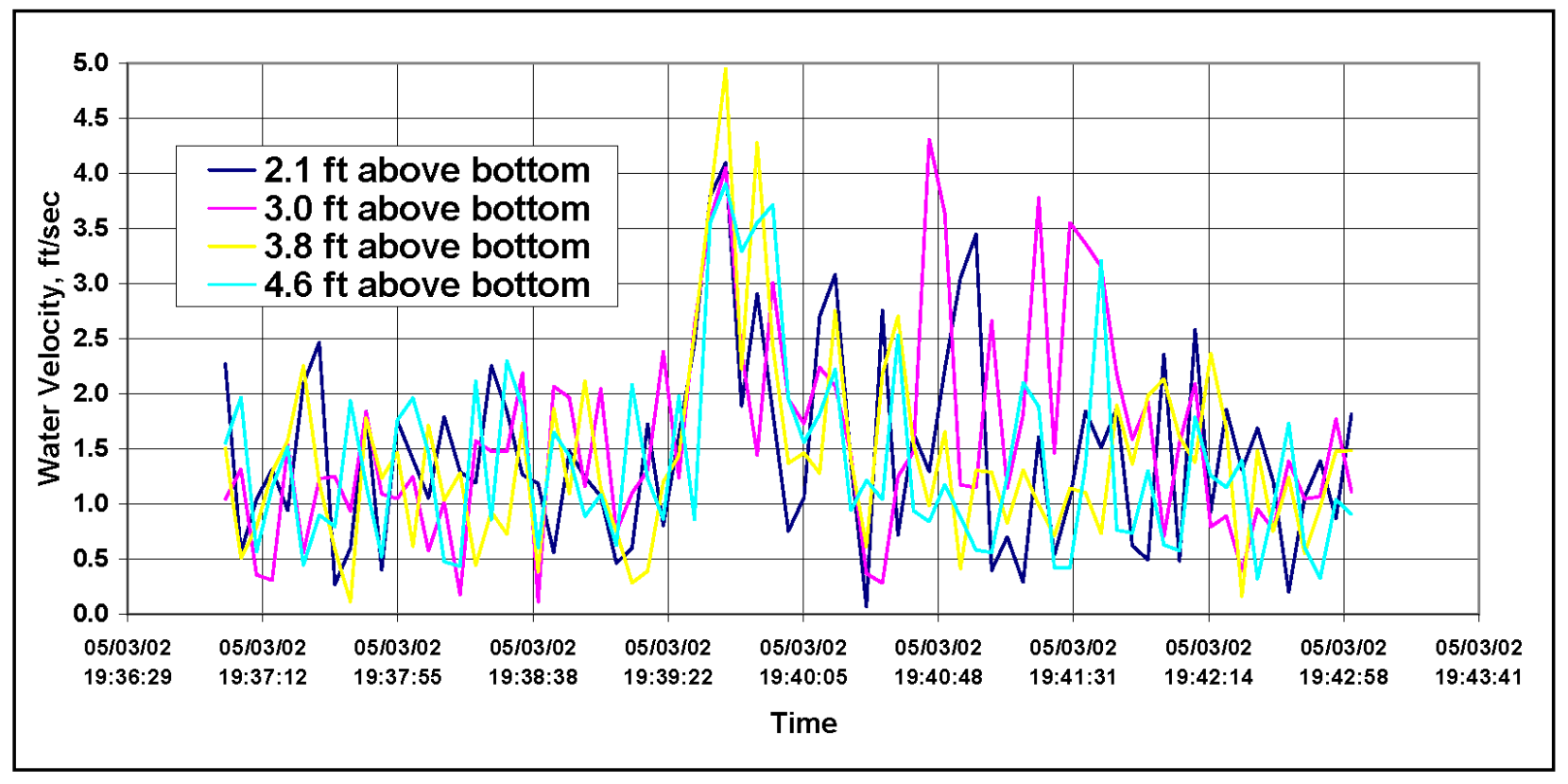

Figure A19. Shetland, inbound, south site, 3 May 2002, water velocity 


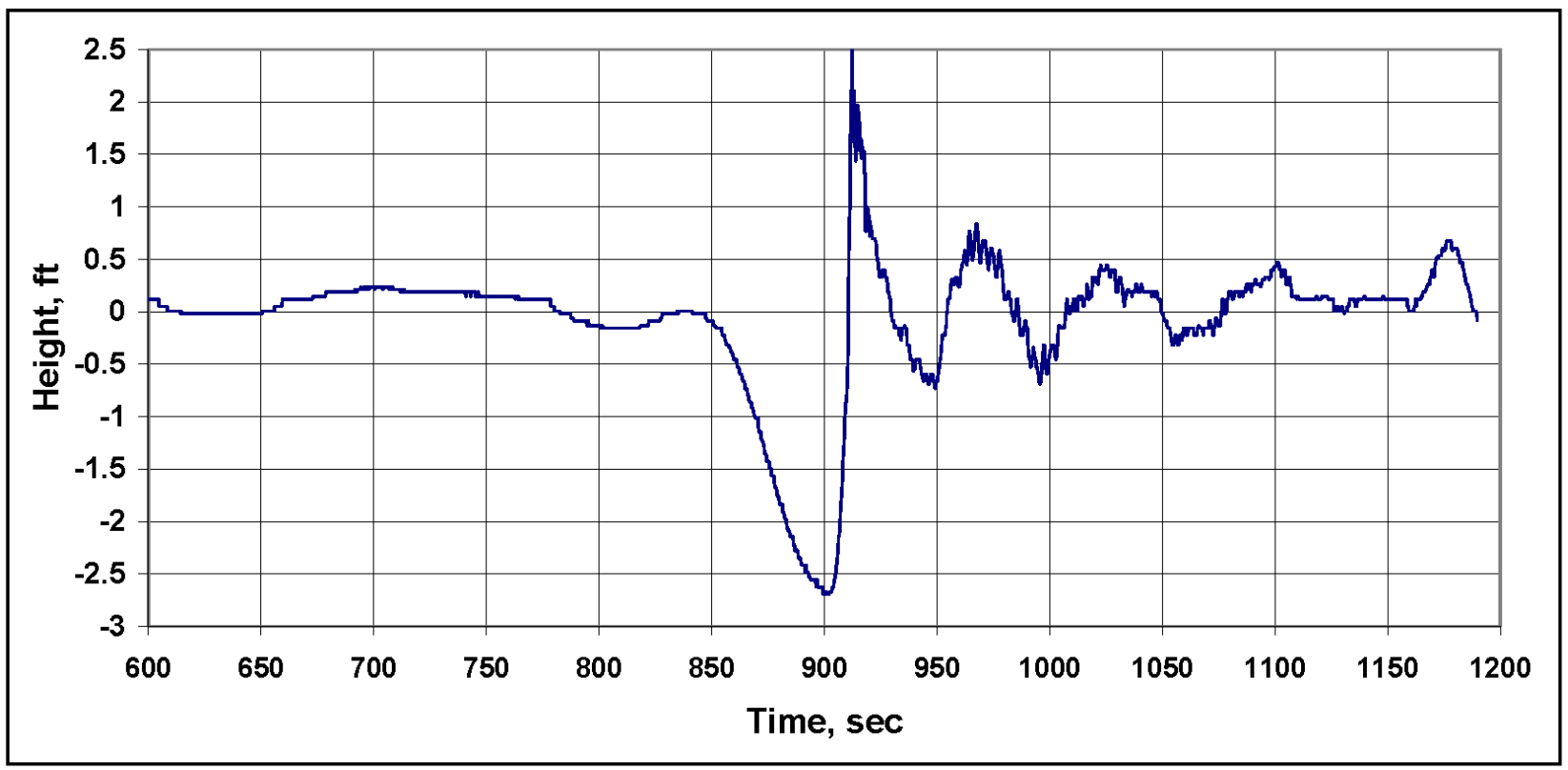

Figure A20. Pacific Sapphire, outbound, south site, time $0=0720,4$ May 2002, pressure cell 1230346b

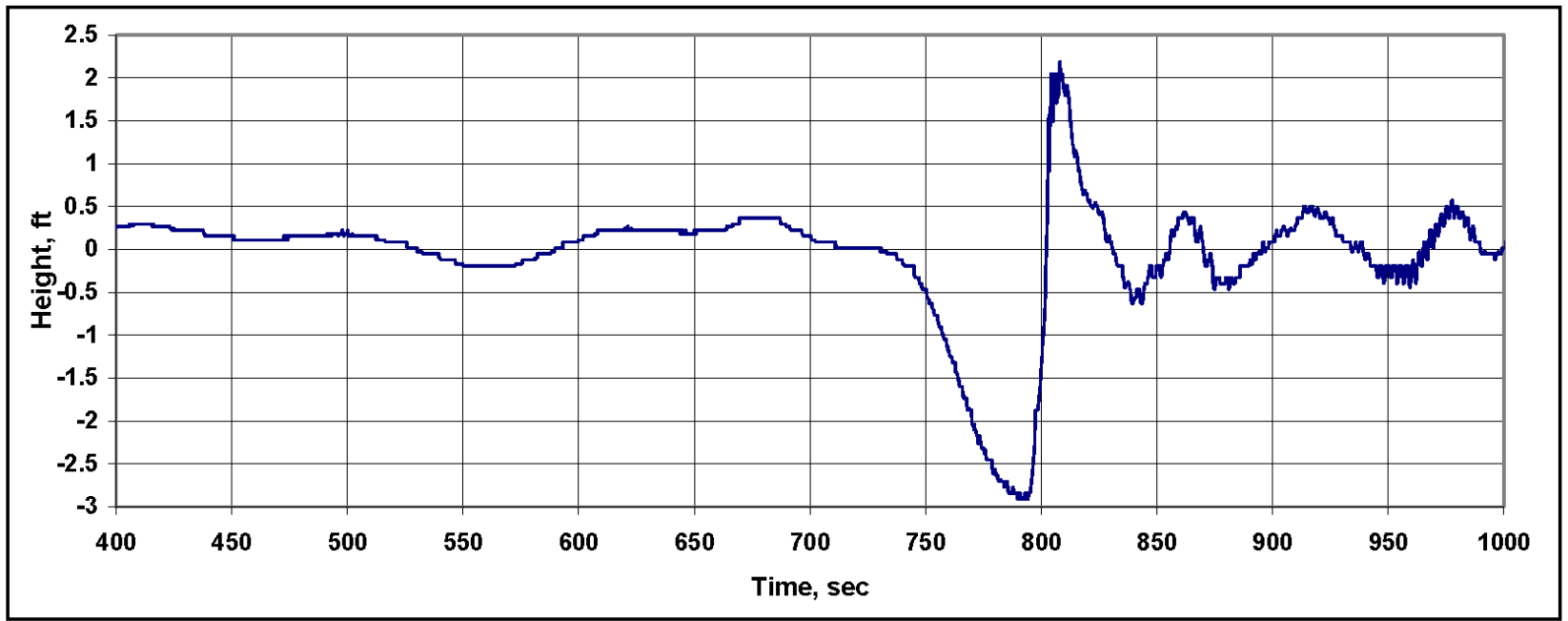

Figure A21. Pacific Sapphire, south site, outbound, time $0=0720,4$ May 2002, pressure cell 1230347b 


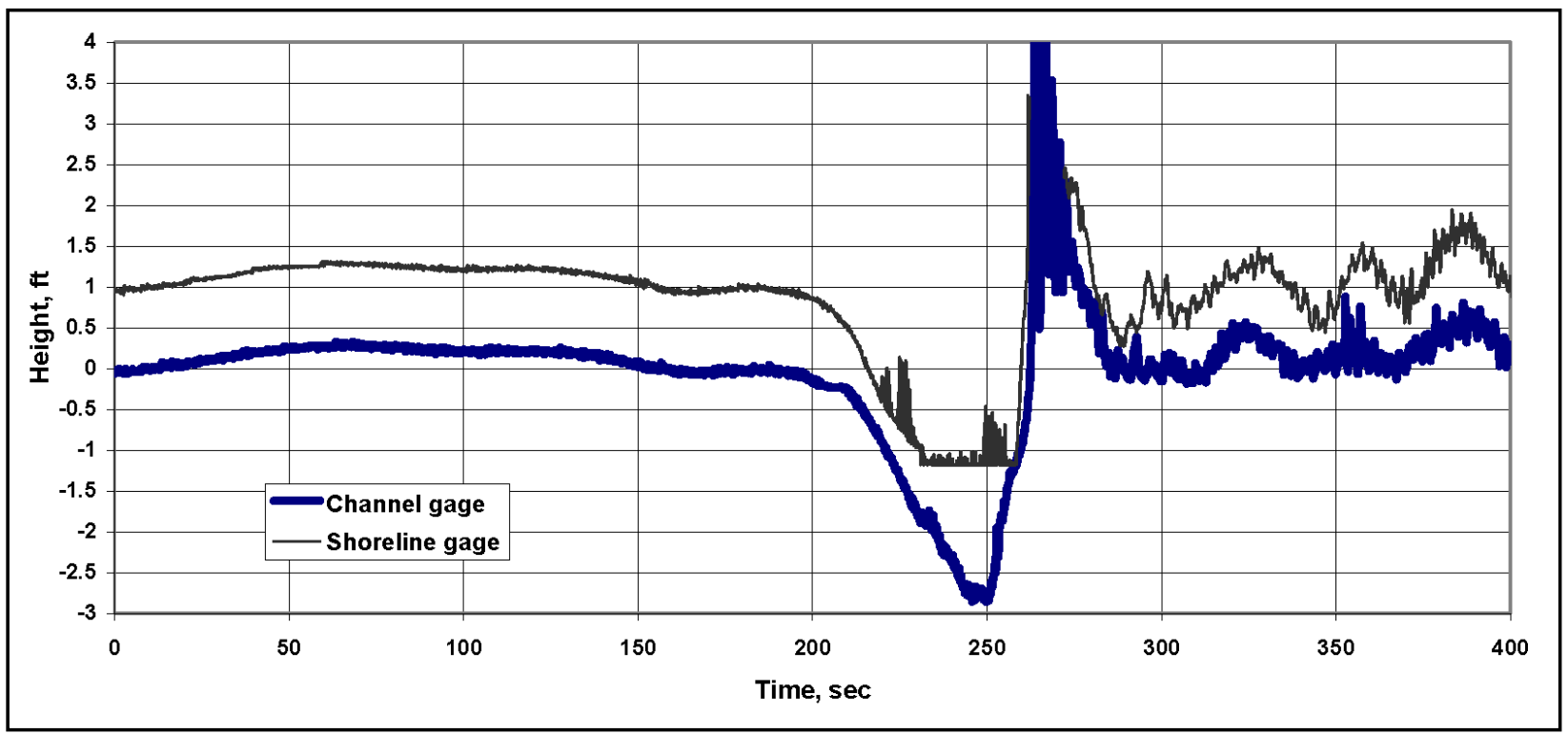

Figure A22. Pacific Sapphire, south site, outbound, time $0=0730,4$ May 2002, capacitance cell $1220526 b$

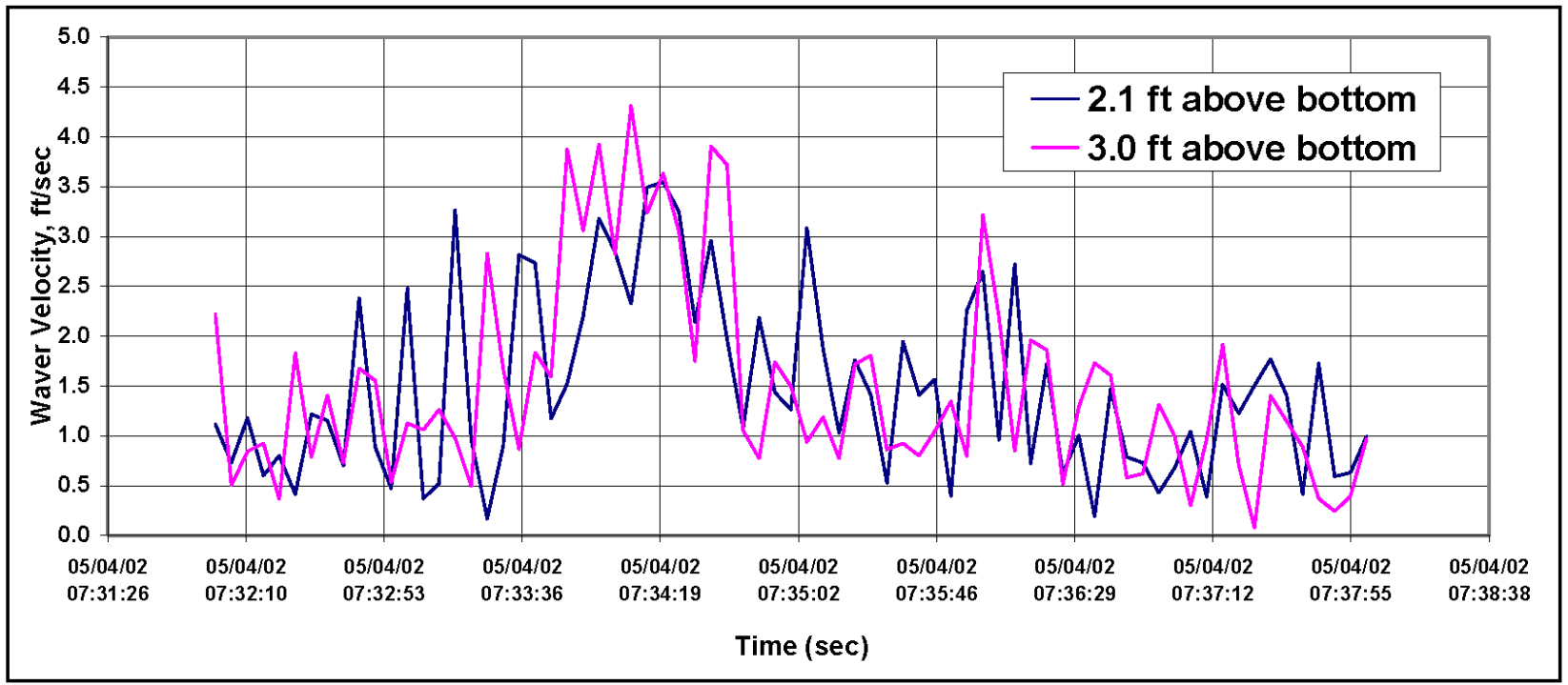

Figure A23. Pacific Sapphire, south site, outbound, 4 May 2002, water velocity 


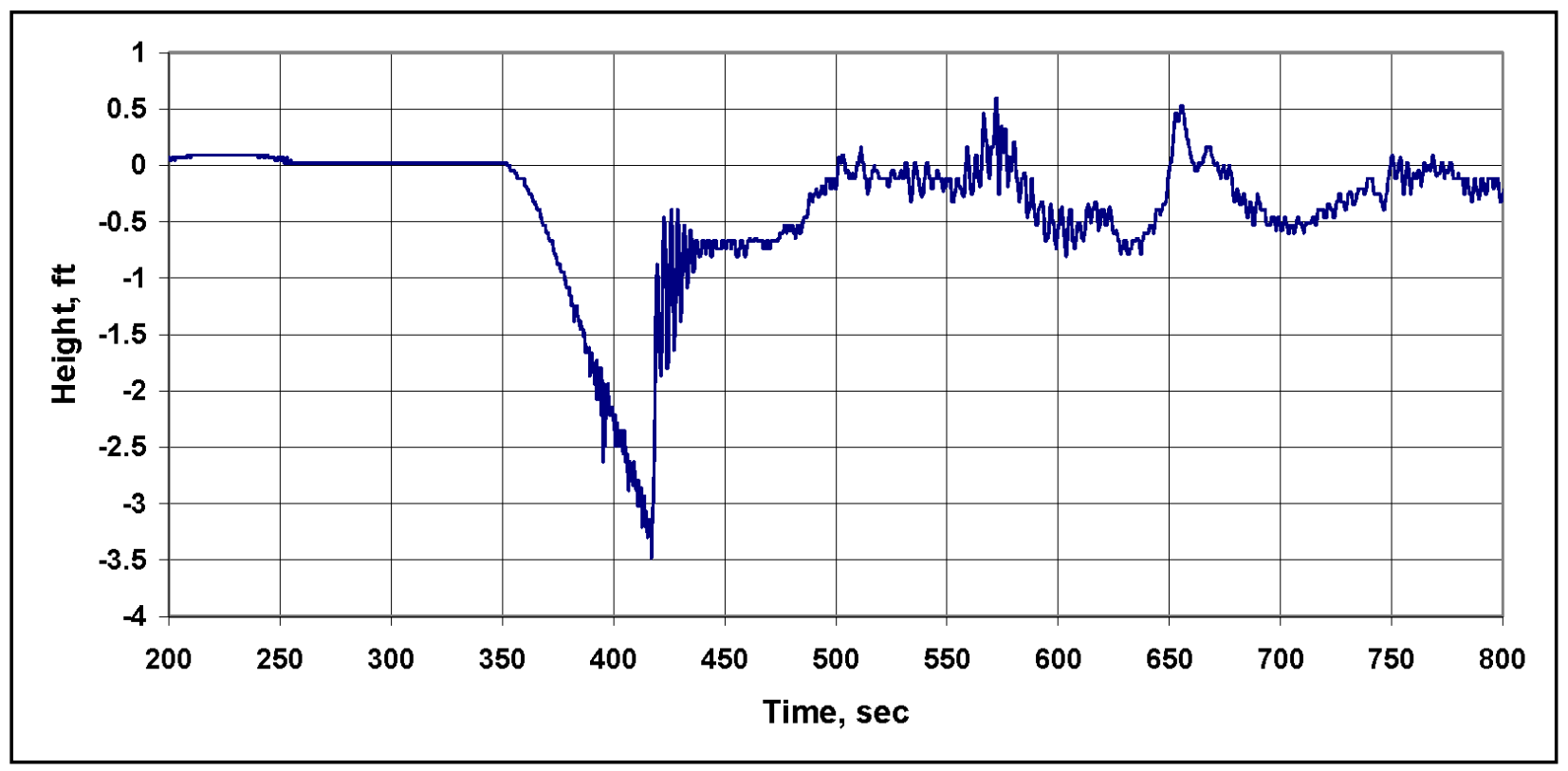

Figure A24. Astro Antares, north site, outbound, time $0=0820,3$ May 2002, pressure cell 1210349b

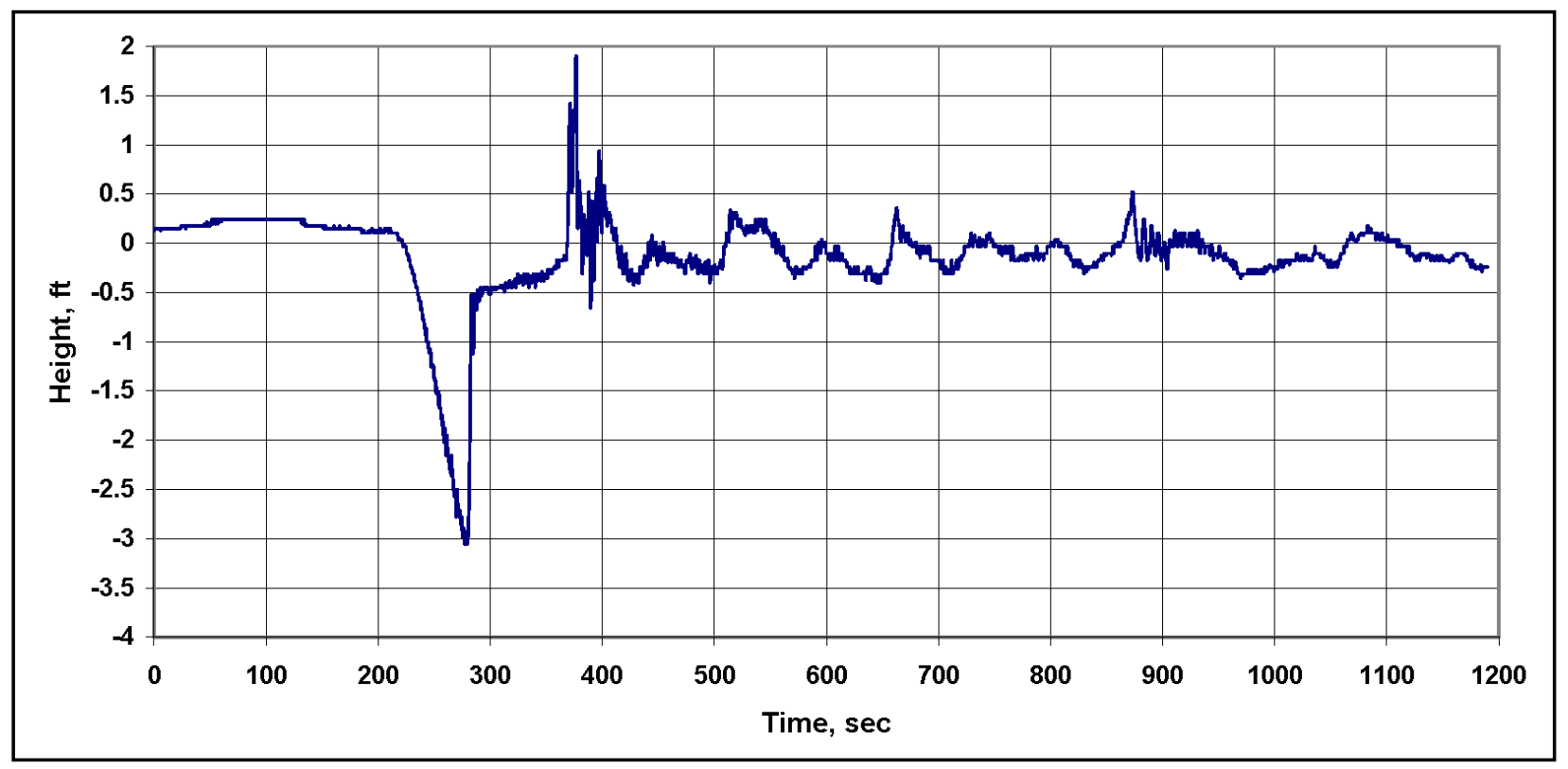

Figure A25. Astro Antares, north site, outbound, time $0=0820,3$ May 2002, pressure cell 1210350b 


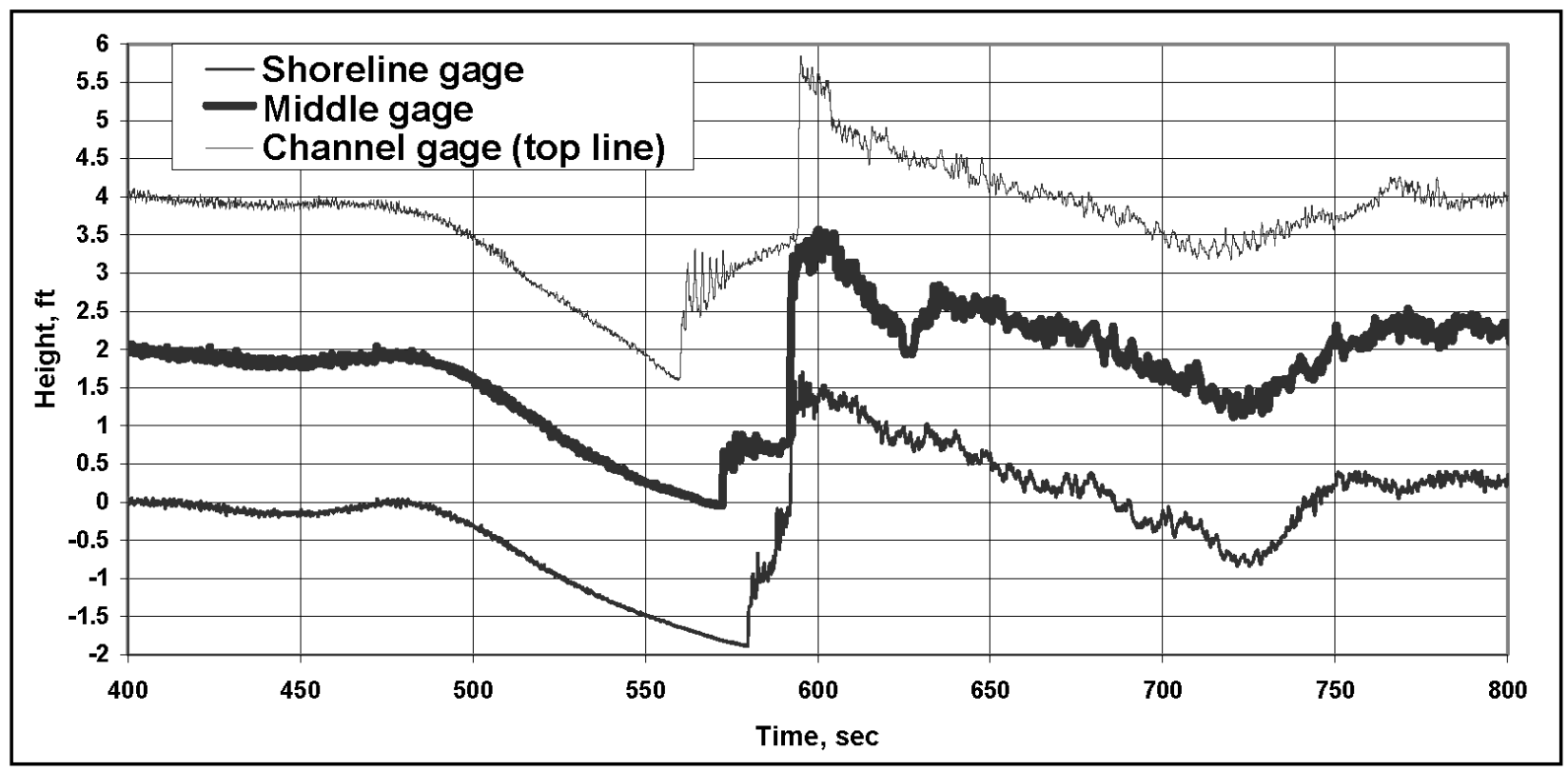

Figure A26. Astro Antares, north site, outbound, time $0=0815,3$ May 2002 capacitance cell 1220522b

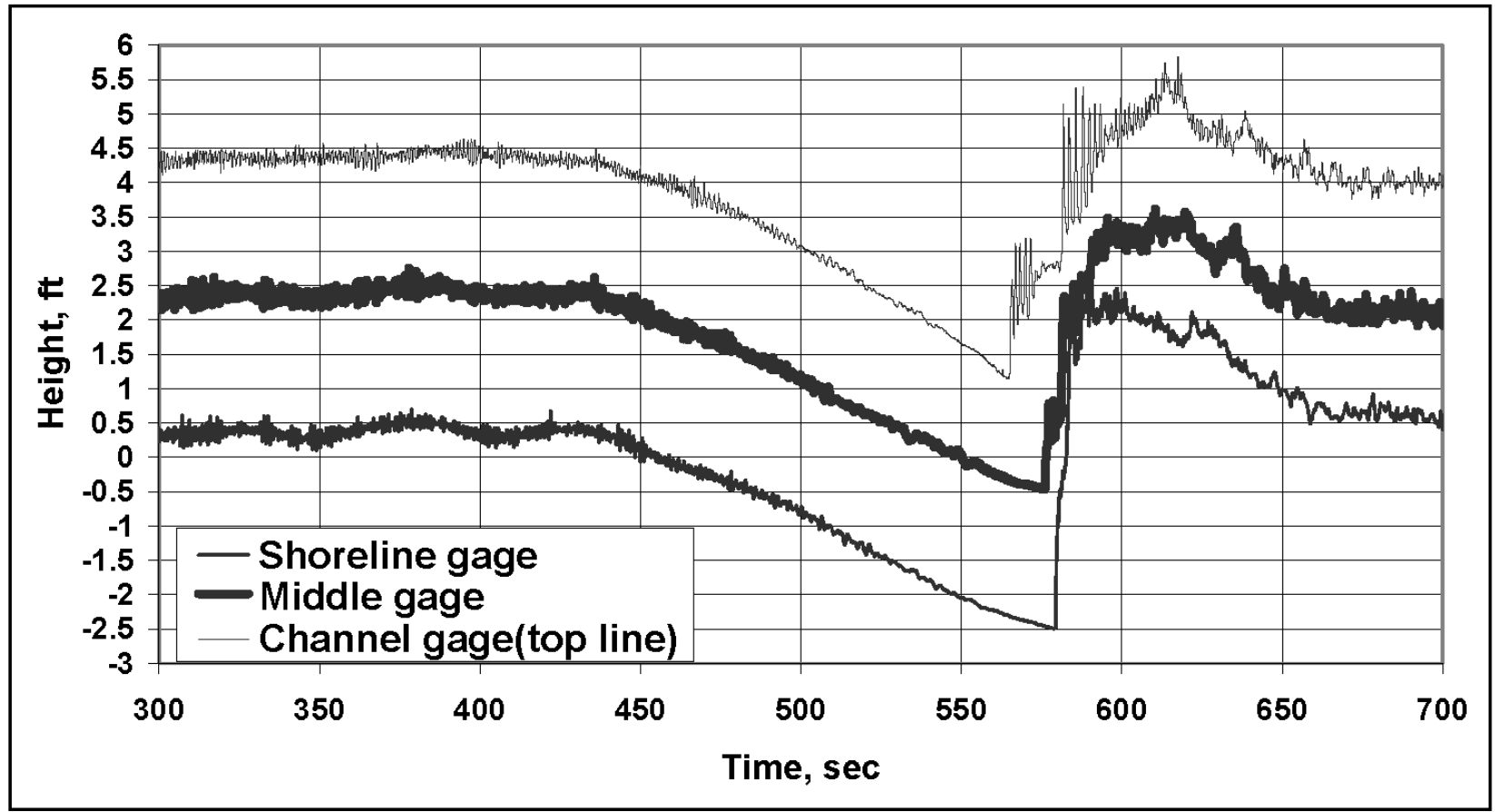

Figure A27. Zrinski, north site, inbound, time $0=1315,1$ May 2002, capacitance cell $1210526 \mathrm{~b}$ 


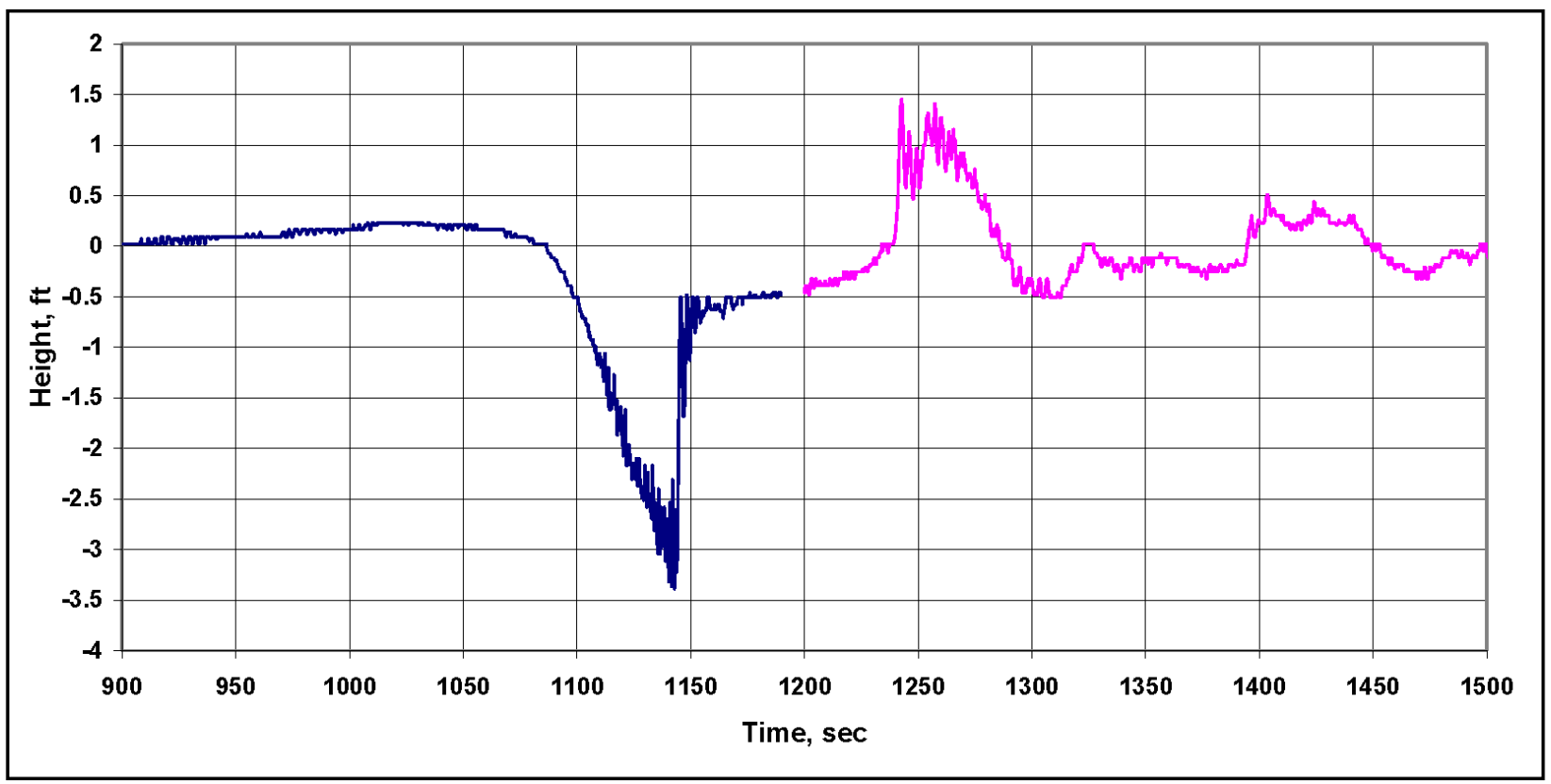

Figure A28. Pacific Sapphire, north site, outbound, time $0=620,4$ May 2002, pressure cell 1230350b

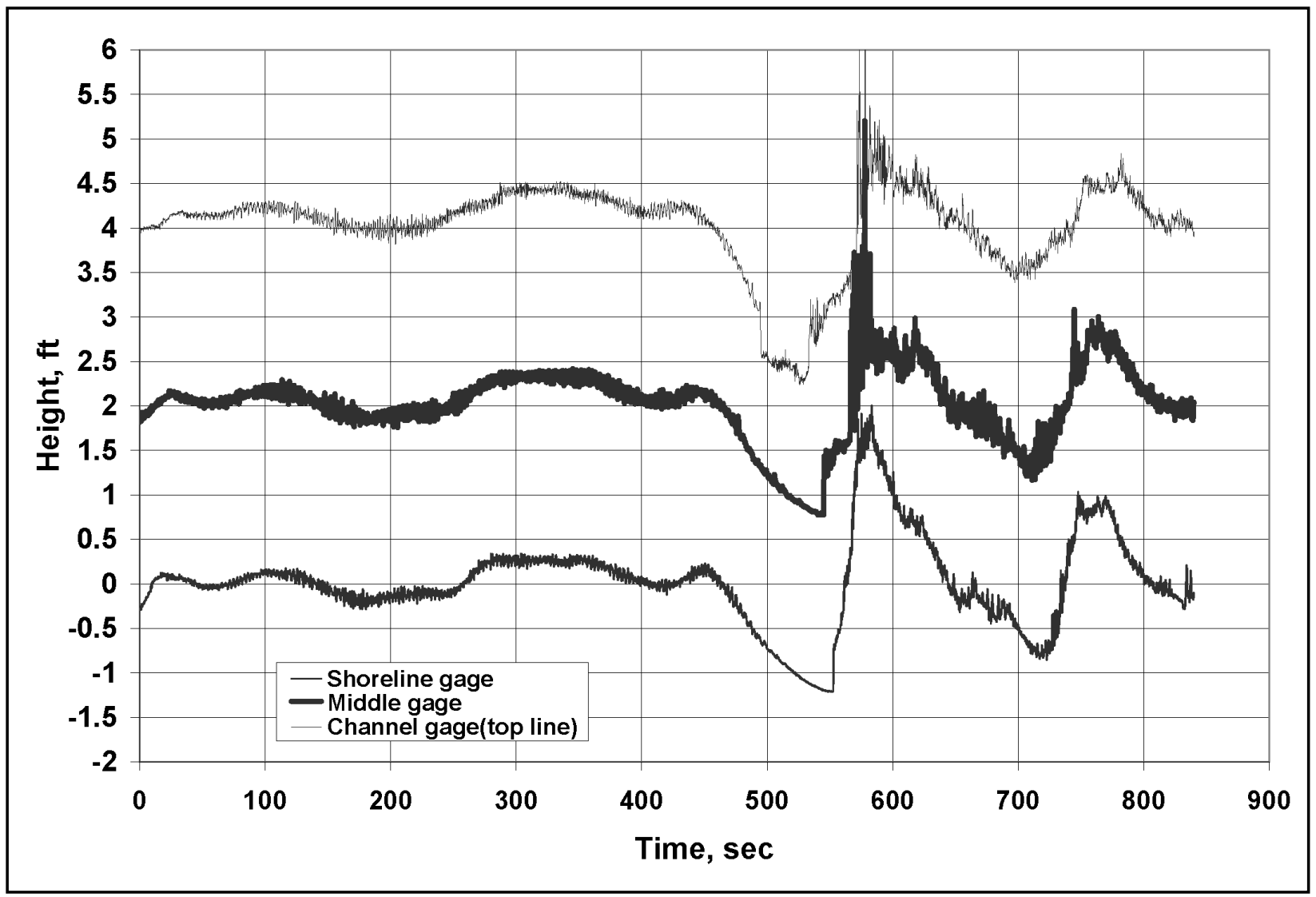

Figure A29. Pacific Sapphire, north site, outbound, time $0=630,4$ May 2002, capacitance cell $1220522 b$ 


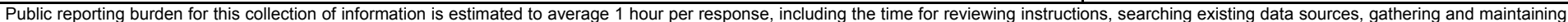

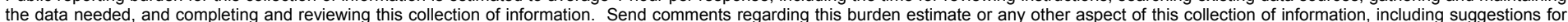

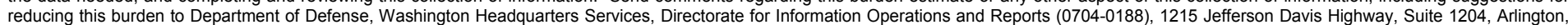

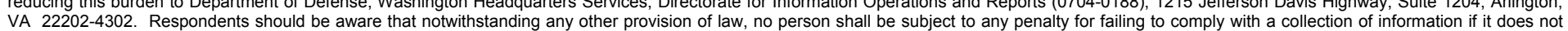
VA 22202-4302. Respondents should be aware that notwithstanding any other provision of law, no person shall be sube
display a currently valid OMB control number. PLEASE DO NOT RETURN YOUR FORM TO THE ABOVE ADDRESS.

\begin{tabular}{l|c}
$\begin{array}{l}\text { 1. REPORT DATE (DD-MM-YYYY) } \\
\text { September } 2003\end{array}$ & $\begin{array}{c}\text { 2. REPORT TYPE } \\
\text { Final report }\end{array}$ \\
\hline
\end{tabular}

\section{TITLE AND SUBTITLE}

Ship Effects Before and After Deepening of Sabine-Neches Waterway, Port Arthur, Texas

\section{DATES COVERED (From - To)}

5a. CONTRACT NUMBER

5b. GRANT NUMBER

5c. PROGRAM ELEMENT NUMBER

\section{AUTHOR(S)}

Stephen R. Maynord

5d. PROJECT NUMBER

5e. TASK NUMBER

5f. WORK UNIT NUMBER

\section{PERFORMING ORGANIZATION NAME(S) AND ADDRESS(ES)}

8. PERFORMING ORGANIZATION REPORT NUMBER

U.S. Army Engineer Research and Development Center

Coastal and Hydraulics Laboratory

ERDC/CHL TR-03-15

3909 Halls Ferry Road

Vicksburg, MS 39180-6199

\section{SPONSORING / MONITORING AGENCY NAME(S) AND ADDRESS(ES)}

10. SPONSOR/MONITOR'S ACRONYM(S)

U.S. Army Engineer District, Galveston

Galveston, TX 77553-1229;

U.S. Army Corps of Engineers

Washington, DC 20314-1000

11. SPONSOR/MONITOR'S REPORT NUMBER(S)

\section{DISTRIBUTION / AVAILABILITY STATEMENT}

Approved for public release; distribution is unlimited.

\section{SUPPLEMENTARY NOTES}

\section{ABSTRACT}

The Sabine-Neches Waterway is a confined navigation channel with a shallow berm adjacent to the navigation channel whose berm width varies from near zero to more than $800 \mathrm{ft}$ in the Sabine-Neches Canal. Ship effects that attack the bank and possibly lead to bank erosion were compared in the before and after enlargement of the channel. Ship speed is the most critical and most difficult parameter to define in such a comparison. At ship speeds typically found in the SNWW, the shallow berm results in a large breaking wave forming adjacent to the shoreline. This wave, referred to herein as the transverse stern wave (TSW), moves at the ship speed and has a magnitude of up to $5.5 \mathrm{ft}$ based on measurements reported herein and is calculated to be up to $8.4 \mathrm{ft}$ for extremely fast ships in the proposed channel. The TSW is used herein to quantify and compare ship effects on the shoreline.

HIVEL2D is a two-dimensional numerical model that was used herein to compare ship effects at SNWW. The model was validated using data from one of the ships measured during the field data collection portion of this study.

Two scenarios were evaluated that have the potential for increased bank attack in the proposed channel. The first scenario is that ships currently using the SNWW will be able to travel faster in the larger proposed channel resulting in an increase in bank attack. The second scenario is that future ships will be larger than those using the existing SNWW and will cause larger bank attack. The two bank attack scenarios were evaluated using a range of speeds for ships in the existing and proposed channels.

(Continued)

\section{SUBJECT TERMS}

Bank erosion

Deep-draft ships

16. SECURITY CLASSIFICATION OF:

\begin{tabular}{|l|l|l|}
\hline $\begin{array}{l}\text { a. REPORT } \\
\text { UNCLASSIFIED }\end{array}$ & b. ABSTRACT & c. THIS PAGE \\
UNCLASSIFIED & UNCLASSIFIED
\end{tabular}

Navigation

Numerical modeling

\section{Waves}

\begin{tabular}{|l|c|l|}
$\begin{array}{l}\text { 17. LIMITATION } \\
\text { OF ABSTRACT }\end{array}$ & $\begin{array}{l}\text { 18. NUMBER } \\
\text { OF PAGES }\end{array}$ & $\begin{array}{l}\text { 19a. NAME OF RESPONSIBLE } \\
\text { PERSON }\end{array}$ \\
\cline { 3 - 3 } & 84 & $\begin{array}{l}\text { 19b. TELEPHONE NUMBER (include } \\
\text { area code) }\end{array}$ \\
& & \\
\hline
\end{tabular}




\section{4. (Concluded)}

Results show that at the lower end of the range of speeds evaluated in the proposed channels, the TSW will increase in height less than 10 percent for both bank attack scenarios in both the Port Arthur and Sabine-Neches Canals. At the upper end of the range of speeds evaluated in the proposed channels, the TSW will increase an average of 35 percent in the Port Arthur Canal and an average of 17 percent in the Sabine-Neches Canal for both bank attack scenarios. The lesser change in the Sabine-Neches Canal is due to the smaller increase in cross section and the wider berm.

Speed restriction tests were conducted with the proposed channel to determine speeds that will (a) result in equal TSW in the existing and proposed channels and (b) lessen TSW in the proposed channel compared to the existing channel. 